University of South Florida

DIGITAL COMMONS

Digital Commons @ University of

@ UNIVERSITY OF SOUTH FLORIDA

South Florida

$5-15-2003$

\title{
Melting Processes and Fluid and Sediment Transport Rates Along the Alaska-Aleutian Arc from an Integrated U-Th-Ra-Be Isotope Study
}

\author{
Rhiannon George \\ University of Bristol \\ Simon Turner \\ University of Bristol \\ Chris Hawkesworth \\ University of Bristol \\ Julie Morris \\ Washington University \\ Chris Nye \\ Alaska Division of Geological and Geophysical Surveys
}

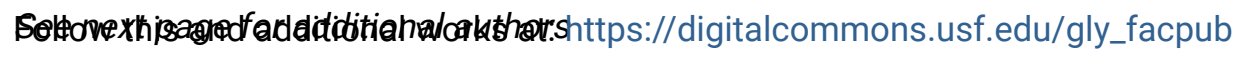

Part of the Geochemistry Commons, Geology Commons, and the Geophysics and Seismology

\section{Commons}

\section{Scholar Commons Citation}

George, Rhiannon; Turner, Simon; Hawkesworth, Chris; Morris, Julie; Nye, Chris; Ryan, Jeffrey G.; and Zheng, Shu-Hui, "Melting Processes and Fluid and Sediment Transport Rates Along the Alaska-Aleutian Arc from an Integrated U-Th-Ra-Be Isotope Study" (2003). Geology Faculty Publications. 16. https://digitalcommons.usf.edu/gly_facpub/16 
Authors

Rhiannon George, Simon Turner, Chris Hawkesworth, Julie Morris, Chris Nye, Jeffrey G. Ryan, and Shu-Hui Zheng 


\title{
Melting processes and fluid and sediment transport rates along the Alaska-Aleutian arc from an integrated U-Th-Ra-Be isotope study
}

\author{
Rhiannon George, ${ }^{1}$ Simon Turner, ${ }^{1}$ Chris Hawkesworth, ${ }^{1}$ Julie Morris, ${ }^{2}$ Chris Nye, ${ }^{3}$ \\ Jeff Ryan, ${ }^{4}$ and Shu-Hui Zheng ${ }^{5}$ \\ Received 5 April 2002; revised 3 December 2002; accepted 24 January 2003; published 15 May 2003.
}

[1] A comprehensive data set for young lavas erupted along the Alaska-Aleutian arc is used to examine how fluid and sediment transport rates and melting processes vary in response to systematic changes in subduction rate and dip along the arc and across the ocean-continent boundary. Positive correlations between convergence rate, volcano volume, and ${ }^{238} \mathrm{U}$ excesses suggest that magmatic output is closely linked to the size of the fluid flux which occurred $<10 \mathrm{kyr}$ prior to eruption. Sediment-sensitive tracers like $\mathrm{Th} / \mathrm{Nb}$, $\mathrm{Ce} / \mathrm{Ce}$, and ${ }^{10} \mathrm{Be} /{ }^{9} \mathrm{Be}$ also increase with convergence rate. However, the inferred ${ }^{10} \mathrm{Be} /{ }^{9} \mathrm{Be}$ ratio of this component is low relative to that in the incoming sediments, and this could reflect either sediment removal by accretion or storage in the mantle wedge for $\sim 0.5-1 \mathrm{Myr}$. $\mathrm{Th} / \mathrm{Nb}$ and $\mathrm{Th} / \mathrm{Nd}$ ratios exceed those expected from bulk sediment addition in the center of the arc suggesting that the enhanced sediment signal reflects transfer in a partial melt phase, whereas partial melts from the subducted oceanic crust appear to be restricted to the western tear in the Pacific plate. Therefore the thermal structure at the slabwedge interface in the center of the arc must lie close to, and possibly between, the sediment and basalt solidii and is thus constrained to be in the region of $670-740^{\circ} \mathrm{C}$ at $3 \mathrm{GPa}$. Elevated $\left({ }^{230} \mathrm{Th} /{ }^{232} \mathrm{Th}\right)$ ratios, the occurrence of ${ }^{230} \mathrm{Th}$ excesses and only modest ${ }^{226} \mathrm{Ra}$ excesses in many of the lavas are modeled as the products of dynamic melting effects superimposed upon a fluid-fluxed mantle wedge. The transition from oceanic to continental lithosphere seems to play an important role in determining the relative effects of fluid addition and partial melting upon U-Th disequilibria. We infer that the change from fast and steep plate subduction in the Aleutians to shallow and slow subduction, coupled with increasing lithospheric lid thickness, in Alaska together control slab and wedge temperatures and the rate of matrix flow through the melting region. INDEX TERMS: 1040 Geochemistry: Isotopic composition/chemistry; 8434 Volcanology: Magma migration; 8450 Volcanology: Planetary volcanism (5480); KEYWORDS: uranium series, beryllium isotopes, Aleutians, Alaska, arc petrogenesis

Citation: George, R., S. Turner, C. Hawkesworth, J. Morris, C. Nye, J. Ryan, and S.-H. Zheng, Melting processes and fluid and sediment transport rates along the Alaska-Aleutian arc from an integrated U-Th-Ra-Be isotope study, J. Geophys. Res., 108(B5), 2252, doi:10.1029/2002JB001916, 2003.

\section{Introduction}

[2] Subduction zones provide insights into the nature of crustal recycling and are the principal present-day sites of new crustal additions [Kay and Kay, 1991; Kelemen, 1995]. However, there has been debate over the extent to which the bulk continental crust is generated at arcs and whether partial melts of the subducting oceanic crust play an

\footnotetext{
${ }^{1}$ Department of Earth Sciences, University of Bristol, Bristol, UK

${ }^{2}$ Department of Earth and Planetary Sciences, Washington University, Saint Louis, Missouri, USA.

${ }^{3}$ Alaska Volcano Observatory, Alaska Division of Geological and Geophysical Surveys, Fairbanks, Alaska, USA.

${ }^{4}$ Department of Geology, University of South Florida-Tampa, Tampa, Florida, USA.

${ }^{5}$ Department of Earth System Science, University of California, Irvine, California, USA.
}

Copyright 2003 by the American Geophysical Union. 0148-0227/03/2002JB001916\$09.00 important role in this. Many recent geochemical models infer separate additions of sediment and fluid components to a mantle wedge source without the need for involvement of melts of the subducting basaltic crust [e.g., Hawkesworth et al., 1997; Class et al., 2000]. Thus the dominant flux into volcanic arcs from the mantle has been thought to be basaltic in composition, as is the flux which supplies the growth of continental crust [e.g., Ellam and Hawkesworth, 1988]. However, the debate has recently been reinvigorated through the suggestion that primary high $\mathrm{Mg}$ number andesites are more representative of the influxes into the arc crust than previously thought, and that these rarely erupted compositions are the key to the formation of average continental crust in arc settings [Defant and Drummond, 1990; Kelemen, 1995; Kelemen et al., 1998; 2003].

[3] A second issue is that a better knowledge of the nature of the subducted components added to arc lavas, and in particular their temperatures of mobilization, would place important constraints on the thermal structure of the mantle 
wedge. For example, numerical models indicate that the subducting oceanic crust may only melt if it is young and hot [Peacock et al., 1994]. On the other hand, many recent geochemical studies have concluded that the sediment component in arc lavas was added to their mantle source as a partial melt [Plank and Langmuir, 1993; Hoogewerff et al., 1997; Class et al., 2000; Johnson and Plank, 1999; Elliott et al., 1997; Turner et al., 1997]. This would appear to imply slab surface temperatures in excess of those proposed in models by Davies and Stevenson [1992] and Peacock [1996] but lower than those required for melting of the oceanic crust [Nichols et al., 1996]. Thus it may be possible to bracket the likely temperature structure of the slab surface beneath the arc volcanoes.

[4] A third important question surrounding arc magma genesis is the extent to which a decompression melting effect on trace element and $U$ series isotope ratios can be distinguished from those produced by hydrous flux-driven melting. Decompression melting beneath ridges and ocean islands is well supported by both major and trace element studies [e.g., Langmuir et al., 1992; McKenzie and Bickle, 1988] and by the presence of ${ }^{230} \mathrm{Th}$ excesses [e.g., Cohen and O'Nions, 1993; Volpe and Goldstein, 1993; Lundstrom et al., 1995]. Such ${ }^{230} \mathrm{Th}$ excesses could reflect melting processes in either garnet or spinel stability fields [Wood et al., 1999]. Several major and trace element studies have similarly argued for decompression melting beneath arcs [Plank and Langmuir, 1988; Pearce and Parkinson, 1993], and Pickett and Murrell [1997] have independently shown that ${ }^{231} \mathrm{~Pa}$ excesses are observed in most arc lavas and inferred that these reflect fractionation of $\mathrm{Pa} / \mathrm{U}$ during melting subsequent to fluid addition of $\mathrm{U}$. The ${ }^{230} \mathrm{Th}$ and ${ }^{231} \mathrm{~Pa}$ excesses can be explained by differences in the melt and matrix velocities through the melting zone, and so Bourdon et al. [1999] have suggested that ${ }^{231} \mathrm{~Pa}$ excesses in the Tonga-Kermadec arc could reflect dynamic, decompression melting, whereas Thomas et al. [2002] have modeled ${ }^{231} \mathrm{~Pa}$ excesses in central America to result from flux melting in a downward convecting mantle wedge without any need for decompression. However, ${ }^{230} \mathrm{Th}$ excesses are rarely observed in arc lavas, and it is unclear whether this is because $U$ excesses produced by fluid addition are too large to be completely overprinted by ${ }^{230} \mathrm{Th}$ increases produced during melting or whether this provides evidence that decompression melting does not generally occur in this tectonic setting [Condomines and Sigmarsson, 1993]. Rare exceptions to the scarcity of ${ }^{230} \mathrm{Th}$ excesses are arc lavas erupted through thicker continental crust such as in Nicaragua [McDermott and Hawkesworth, 1991; Reagan et al., 1994] and where the young and hot subducting oceanic crust undergoes partial melting under eclogite facies conditions [Sigmarsson et al., 2002].

[5] The Alaska-Aleutian arc was chosen for this study because it provides a unique opportunity to address these three issues in a single arc, thereby circumventing potential problems of interarc variations. First, the Aleutians contain the type locality for adakites, which are thought to be partial melts from the subducted oceanic crust that have interacted with mantle peridotite [Kay, 1978]. Such rocks are also the basis of a recent reappraisal of the generation of high $\mathrm{Mg}$ number andesites in the far western Piip and
Komandorsky islands by Kelemen et al. [2003]. Second, it was one of the first arcs where a clear signal from the subducted sediment was identified [Kay, 1980]. Third, the arc undergoes a transition from oceanic to continental crust at the Alaska Peninsula allowing the possible effects of increasing lithospheric lid thickness on the melting regime to be explored [cf. Plank and Langmuir, 1988]. Finally, because the curvature of the arc results in progressive changes in the angle of plate convergence, the rate of convergence changes smoothly from $7 \mathrm{~cm} \mathrm{yr}^{-1}$ to effectively $0 \mathrm{~cm} \mathrm{yr}^{-1}$ along its $2500 \mathrm{~km}$ length [DeMets et al., 1994; Fournelle et al., 1994]. Despite these alluring features, within over 1000 existing lava analyses (J. Myers and T. McElfrish, unpublished data compilation available at http://www.gg.uwyo.edu/aleutians/index.htm), there are, regrettably, only a handful published which have complete major, trace element and radiogenic isotope data. Here we present the results of a detailed study confined to very young Alaskan-Aleutian arc lavas which includes the first comprehensive investigation of U-Th-Ra and $\mathrm{Be}$ isotope variations along the length of the arc as far as Kiska volcano.

\section{Alaska-Aleutian Arc}

[6] The Alaska-Aleutian arc forms the northernmost segment of the circum-Pacific subduction system, and currently comprises 40 historically active volcanic centers superimposed on eighty volcanic edifices (Figure 1). At the easternmost end, the $\sim 50$ Ma Pacific plate subducts obliquely beneath $30-40 \mathrm{~km}$ thick Alaskan continental crust [Fliedner and Klemperer, 2000]. The ocean-continent transition is marked by the break in slope at $164^{\circ} \mathrm{W}$, and for clarity we subdivide the arc into Alaska and Aleutian segments to the east and west of this shelf break, respectively. At the continent shelf edge, convergence is broadly orthogonal, whereas at the far western end of the arc west of Buldir, the subducting Pacific plate tears in response to increasingly oblique convergence leading to elevated temperatures at the edge of the tearing slab [Yogodzinski et al., 2001]. In this unusual plate tectonic setting volcanic rocks are high $\mathrm{Mg}$ number andesites that are very different from the recent eruptives from the rest of the arc [Yogodzinski et al., 1994, 1995]. It is striking that as the rate of orthogonal convergence increases, so does the maximum subaerial volcano volume erupted in the last $3 \mathrm{Myr}$ (Figure 2a) [Marsh, 1982; Fournelle et al., 1994]. The eruptive products also change character along the arc from predominantly dacites and silicic andesites in the east, to basalts and basaltic andesites farther west in the oceanic sector. This is illustrated in Figures $2 \mathrm{c}$ and $2 \mathrm{~d}$ where continental magmas show a greater tendency toward more evolved compositions from a mode of $50 \mathrm{wt} \% \mathrm{SiO}_{2}$ in the oceans to $58 \mathrm{wt} \% \mathrm{SiO}_{2}$ in the continents.

[7] Previous studies have suggested that some along-arc changes in arc magma geochemistry reflect the changing character of the subducting plate (e.g., the presence of fracture zones (Figure 1) [Singer et al., 1996]) and variations in the length of the melting column resulting from changes in the thickness of the overlying lithospheric lid [Plank and Langmuir, 1988]. By implication, these contrasting models highlight different aspects of the melting 


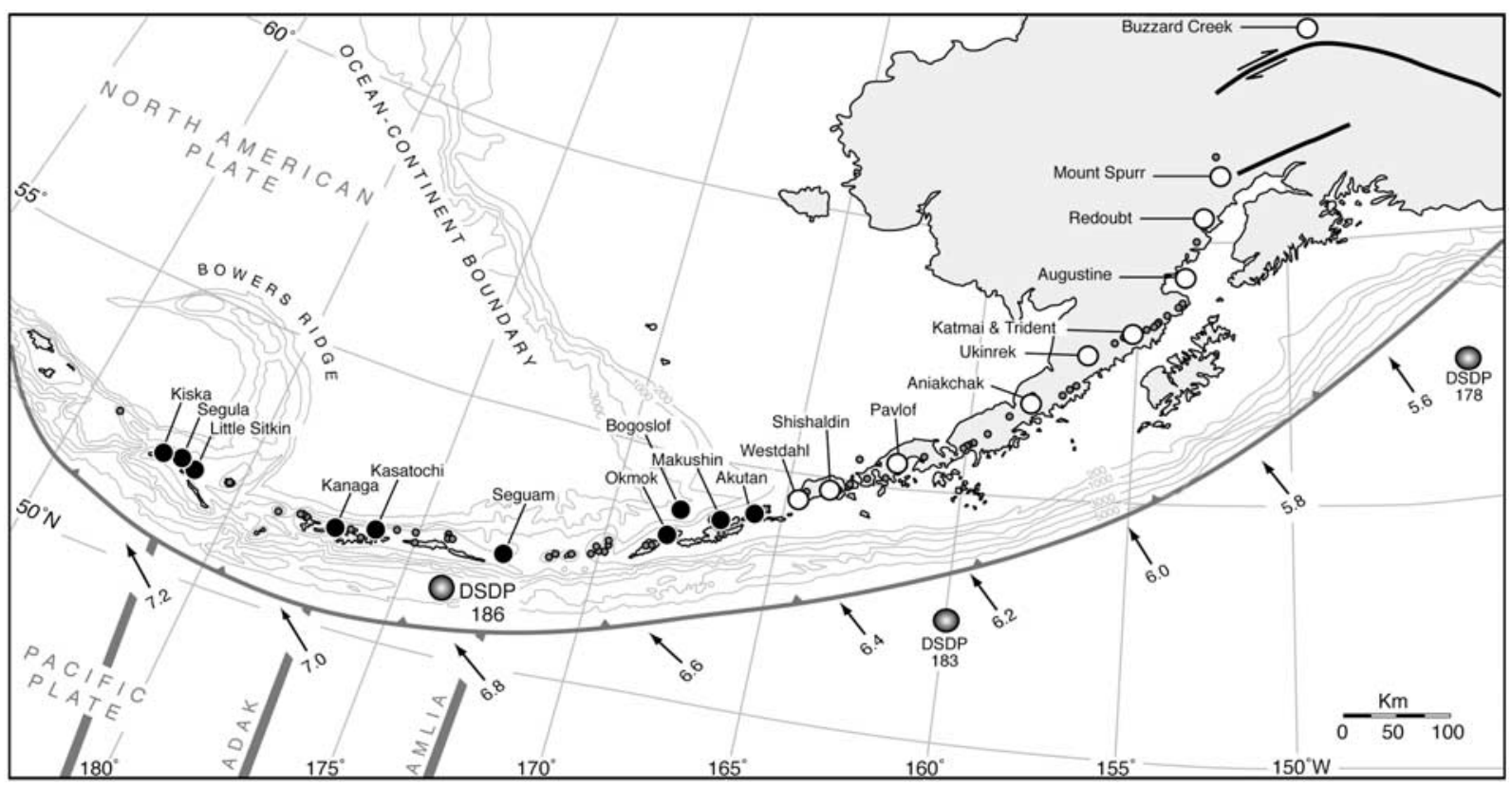

Figure 1. Location map of the Aleutian arc [see Nye et al., 1998]. Historically active volcanoes are shown as shaded circles [Wood and Kienle, 1990], while the active volcanoes analyzed in this study are labeled. Volcanoes are subdivided on the basis of geographic position into intraoceanic (Aleutians sensu stricto) and continental (Alaskan) and these symbols are used in subsequent figures. Convergence vectors and rates of subduction of the Pacific plate beneath the North American plate [DeMets et al., 1994] and the positions of the Rat, Adak, and Amlia fracture zones on the down-going plate are shown [Geist et al., 1988], along with the positions of DSDP sites 183 and 178 [Creager et al., 1973]. Faults in mainland Alaska are shown as bold lines and contours are in meters below sea level.

process: hydrous flux-driven melting and decompression melting, respectively.

[8] The down-going plate delivers a variable sediment flux of $<50-95 \mathrm{~g} \mathrm{~cm} \mathrm{yr}^{-1}$ [Kelemen et al., 2003] to the arc depending on sediment thickness and convergence angle (Figure 2b). The transit time from the trench to beneath the arc volcanoes varies in sympathy with the convergence angle, and it ranges from 3 to $17 \mathrm{Myr}$ (Figure 2b). The compositions of sediments on the down-going Pacific plate are well characterized from analyses of Deep Sea Drilling Project (DSDP) Legs 178 and 183 drill hole sediments [Plank and Langmuir, 1998]; (see Figure 1). The succession comprises $\sim 200 \mathrm{~m}$ of diatomaceous oozes, $<50 \mathrm{~m}$ of green clays and $\sim 100 \mathrm{~m}$ of clastic turbidites and arc-derived volcaniclastics [Geist et al., 1988]. Comparatively greater continental erosion from mainland Alaska to the east and Kamchatka to the west gives rise to more terrigenous material at each end of the arc compared with the pelagicdominated central arc region. A distinctive feature of the bulk composition of the downgoing sediment pile is that it has high abundances of $\mathrm{Ba}, \mathrm{U}, \mathrm{Cs}, \mathrm{Pb}$, and $\mathrm{Rb}$ due to the high biological productivity of the pelagic diatomaceous oozes [Plank and Langmuir, 1998].

\section{Analytical Techniques}

\subsection{Sample Selection and Description}

[9] The most primitive and youngest available samples spanning the length of the arc (Figure 1) were chosen for analysis (16 from Alaska and 14 from the Aleutians). With the exception of two samples, all lavas are from volcanoes at the volcanic front at $\sim 100 \mathrm{~km}$ above the slab. The exceptions are Bogoslof, a true rear arc volcano,; and the Ukinrek sample, a ne-normative alkali olivine basalt erupted from a position $\sim 115 \mathrm{~km}$ above the Benioff zone [Kienle et al., 1979; Kienle and Swanson, 1983]. Most of the samples come from the Alaska Volcano Observatory (AVO) collection at Fairbanks. Five historic lavas from the collection of R. Kay which were analyzed for U-Th isotopes by Newman et al. [1984] and Turner et al. [1998] and Be isotopes by Morris et al. [1990] are represented here supplemented with new ICP-MS trace element data and $\mathrm{Ra}$ isotope analyses. KG21, from Kanaga, is a lava first presented by Brophy [1990]. Samples 54-445 (Kiska), 54-452 (Segula), 52-496 (Little Sitkin), and 46A-By531 (Okmok) are from the collection of M. R. Perfit. Sr and Nd isotopes for the Okmok, Kiska and Segula samples were presented by McCulloch and Perfit [1981], but they have been reanalyzed here. One of the Akutan samples (AK81-35) was first reported by Romick et al. [1990], and since this sample was powdered in tungsten carbide leading to an anomalous $\mathrm{Nb} / \mathrm{Ta}$ ratio, its Ta concentration is not presented here. Although the majority of samples are likely to be from historic eruptions (see Table 1), only those with known historic eruption ages have been analyzed for ${ }^{226} \mathrm{Ra}$. The remaining samples are all considered to be much less than $10 \mathrm{kyr}$ old and are thus amenable to U-Th isotope measurements without need for any age correction. Finally, samples of the incoming sediments at DSDP Site 183, and also for Site 

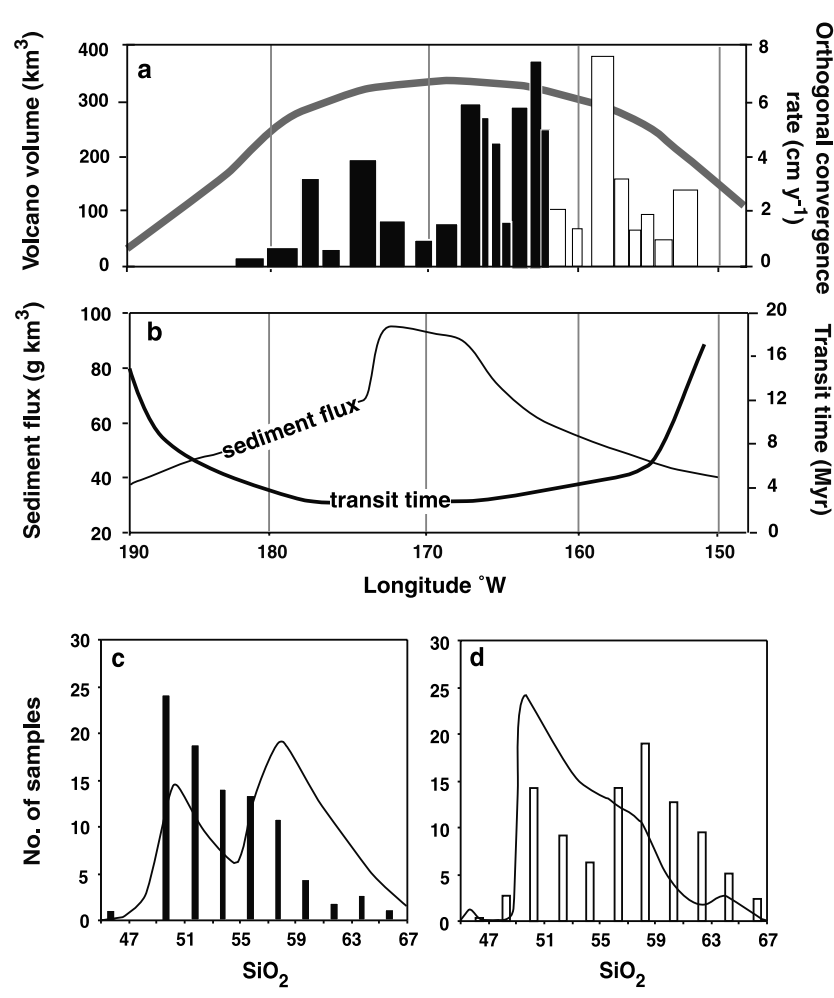

Figure 2. (a) Rate of orthogonal convergence (solid line) compared with volcano volume as a function of location along the arc. The ocean-continent shelf break at $164^{\circ} \mathrm{W}$ is taken as the boundary between continental Alaskan (open bars) and oceanic Aleutian volcanism (solid bars). (b) Calculated along-arc sediment fluxes (light line [Kelemen et al., 2003]) and transit times (solid line) assuming the convergence rates of DeMets et al. [1994] (see also caption to Figure 8). (c) Range of silica in published Aleutian arc lavas (solid bars) from the compilation of J. Myers and T. McElfrish (unpublished data compilation) compared with published Alaskan lavas (solid line). (d) Published Alaskan silica ranges shown as open bars compared with Aleutian samples (solid line).

186 inboard of the trench (see Figure 1) were analyzed for ${ }^{10} \mathrm{Be},{ }^{9} \mathrm{Be}$, and $\mathrm{B}$ concentrations.

\subsection{Major and Trace Elements}

[10] Most XRF major element analyses were measured at the AVO and techniques are described in Appendix A of Nye and Turner [1990]. The remainder (Kiska 62, 99SJP01, NW95 1, and CNBC01) were analyzed at the Open University using techniques described by Potts et al. [1984]. Trace elements were measured by ICP-MS at Durham University for which powders were digested using standard $\mathrm{HF}-\mathrm{HNO}_{3}$ treatments, ensuring that no fluoride residues formed. Internal drift was monitored by spiking with $\mathrm{Rh}$, In, and $\mathrm{Bi}$ before dilution to $3.5 \% \mathrm{HNO}_{3}$. Solutions were analyzed on a Perkin-Elmer-SCIEX Elan 600 inductively coupled plasma mass spectrometer using a cross-flow nebulizer. Oxide interferences for most analyses were much less than $2.5 \%$ of the total signal. Corrections were made using oxide/metal ratios measured on matrix-matched standard solutions, while calibration was achieved using matrix- matched international and in-house reference materials. Total procedural blanks for all elements were negligible for all analyses. Reproducibility, based on replicate digestions of standards and samples, varied between $1.5 \%$ and $3 \%$ for all analyses. The ICP-MS trace element data for sample SAR 7 were provided by T. Plank and were analyzed on a different aliquot to that on which the major element and isotope data were determined.

[11] Samples for $\mathrm{Li}$ and $\mathrm{Be}$ analysis were prepared via $\mathrm{HF}: \mathrm{HClO}_{4}$ acid digestions followed by suspension and dilution to $100: 1$ in $1 \mathrm{M} \mathrm{HNO}_{3}$, as per Ryan and Langmuir [1987, 1988], and were analyzed via direct current plasma (DCP) emission spectrometry at the University of South Florida following standard additions methods. The precision of these measurements is $15 \%$. Samples for B analysis were prepared via the $\mathrm{Na}_{2} \mathrm{CO}_{3}$ fluxed fusion method described by Ryan and Langmuir [1993]. These solutions were analyzed via DCP methods using a matrix-matching method: gravimetric B standards from 0 to $0.5 \mathrm{ppm} \mathrm{B}$ were prepared in a matrix of $\sim 11,000 \mathrm{ppm} \mathrm{Na}$ (i.e., $2 \mathrm{~g} \mathrm{Na}_{2} \mathrm{CO}_{3}$, neutralized with $\mathrm{HNO}_{3}$, per $50 \mathrm{~mL}$ solution). Unknowns were measured against a working curve developed from these standards. Reproducibility of B standards and overall precision vary with concentration: $5 \%$ above $10 \mathrm{ppm}$ and $10 \%$ below.

\subsection{Radiogenic Isotopes}

[12] $\mathrm{Sr}, \mathrm{Nd}$, and $\mathrm{Pb}$ were separated by standard chromatographic exchange separation techniques following HF$\mathrm{HNO}_{3}$ dissolutions at either the Open University or at Adelaide University. The $\mathrm{Nd}$ isotopes for samples CNBC01, 99SH08, AK81-35, 96PN08, 99SJP01, KG21, 52-496, 54-452, 54-445, and Kiska 1962 were run on a Finnegan MAT 262 at Adelaide University. The value for the La Jolla standard in this laboratory over the period of study was ${ }^{143} \mathrm{Nd} /{ }^{144} \mathrm{Nd}=0.511838 \pm 21(2 \sigma)$. Sr and the remaining $\mathrm{Nd}$ isotopes were analyzed on Finnegan MAT 261 and 262 instruments at the Open University. During the project, measured ratios for standards at the Open University were NBS $987{ }^{87} \mathrm{Sr} /{ }^{86} \mathrm{Sr}=0.710170 \pm 28$, and Johnson-Matthey $(\mathrm{J} \& \mathrm{M}){ }^{143} \mathrm{Nd} /{ }^{144} \mathrm{Nd}=0.511755 \pm 25$. $\mathrm{Sr}$ isotope ratios were normalized to an equivalent NBS 987 ${ }^{87} \mathrm{Sr} /{ }^{86} \mathrm{Sr}$ value of 0.71025 and since the J\&M and $\mathrm{La}$ Jolla $\mathrm{Nd}$ are from the same batch of $\mathrm{Nd}$ we have normalized all the $\mathrm{Nd}$ results to an equivalent $\mathrm{La}$ Jolla ${ }^{143} \mathrm{Nd} /{ }^{144} \mathrm{Nd}$ ratio of 0.511838 . For all data $\mathrm{Sr}$ was fractionation corrected to ${ }^{86} \mathrm{Sr} /{ }^{88} \mathrm{Sr}=0.1194$ and $\mathrm{Nd}$ to ${ }^{146} \mathrm{Nd} /{ }^{144} \mathrm{Nd}=0.7219$. The $\mathrm{Sr}$ isotope analysis of sample KG21 is within error of that published by Brophy [1990]. $\mathrm{Pb}$ isotopes were analyzed either on a $\mathrm{Nu}$-Instruments multicollector ICP-MS at the Open University using Tl for mass fractionation correction [Belshaw et al., 1998] or by thermal ionization mass spectrometry at Adelaide University, in which case isotope ratios were corrected for $\sim 1 \%$ o per atomic mass unit mass fractionation using the recommended values of NBS 981 [Todt et al., 1996]. Total procedural blanks were less than $1 \mathrm{ng}, 500 \mathrm{pg}$, and $500 \mathrm{pg}$ for $\mathrm{Sr}, \mathrm{Nd}$, and $\mathrm{Pb}$, respectively.

\subsection{U-Th-Ra Isotopes}

[13] U-Th-Ra separations were carried out on standard $\mathrm{HF}-\mathrm{HCl}-\mathrm{HNO}_{3}$ dissolutions to which a mixed ${ }^{229} \mathrm{Th}^{236} \mathrm{U}$ tracer had been added. Samples were treated with $\mathrm{HCl}$ and 
Table 1. Analyses of Samples From the Alaska-Aleutian Arc

\begin{tabular}{|c|c|c|c|c|c|c|c|c|c|c|}
\hline & \multicolumn{10}{|c|}{ Sample } \\
\hline & Kiska 62 & $54-445$ & $54-452$ & $52-496$ & KG21 & KAN 5-8 & K81-7A & 99SJP01 & 46A By 531 & UM21 \\
\hline Volcano & Kiska & Kiska & Segula & Little Sitkin & Kanaga & Kanaga & Kasatochi & Seguam & Umnak & Okmok \\
\hline Age & 1962 & historic & historic & 1900 & 1850 & 1900 & 1899 & historic & 1946 & 1946 \\
\hline $\mathrm{SiO}_{2}$, wt $\%$ & 55.22 & 49.29 & 51.20 & 58.63 & 55.50 & 53.65 & 49.07 & 52.66 & 48.07 & 52.24 \\
\hline $\mathrm{TiO}_{2}$ & 0.75 & 0.82 & 0.68 & 0.75 & 0.79 & 0.68 & 0.66 & 0.75 & 0.73 & 1.09 \\
\hline $\mathrm{Al}_{2} \mathrm{O}_{3}$ & 18.68 & 15.64 & 19.13 & 17.04 & 17.87 & 17.68 & 15.75 & 18.10 & 15.61 & 17.62 \\
\hline $\mathrm{Fe}_{2} \mathrm{O}_{3} \mathrm{~T}$ & 7.88 & 10.06 & 8.48 & 6.65 & 7.95 & 7.85 & 9.80 & 8.99 & 10.10 & 10.78 \\
\hline $\mathrm{MnO}$ & 0.15 & 0.15 & 0.16 & 0.15 & 0.15 & 0.18 & 0.14 & 0.16 & 0.17 & 0.15 \\
\hline $\mathrm{MgO}$ & 3.80 & 10.70 & 5.65 & 3.19 & 5.10 & 5.51 & 8.77 & 5.73 & 12.68 & 4.97 \\
\hline $\mathrm{CaO}$ & 8.47 & 9.93 & 11.50 & 7.15 & 9.07 & 8.39 & 12.52 & 10.85 & 10.76 & 10.80 \\
\hline $\mathrm{NaO}_{2}$ & 3.50 & 2.61 & 2.39 & 3.37 & 3.29 & 3.38 & 2.24 & 2.69 & 1.86 & 2.91 \\
\hline $\mathrm{K}_{2} \mathrm{O}$ & 1.11 & 0.44 & 0.71 & 1.33 & 1.38 & 1.71 & 0.76 & 0.53 & 0.48 & 0.66 \\
\hline $\mathrm{P}_{2} \mathrm{O}_{5}$ & 0.17 & 0.11 & 0.18 & 0.15 & 0.00 & 0.00 & 0.15 & 0.10 & 0.12 & 0.00 \\
\hline Total & 99.74 & 99.75 & 100.08 & 98.41 & 101.10 & 99.03 & 99.86 & 100.56 & 100.58 & 101.22 \\
\hline $\mathrm{Li}, \mathrm{ppm}$ & 14.2 & - & - & - & 10.4 & - & - & 12.6 & - & - \\
\hline $\mathrm{Be}$ & 0.76 & - & - & - & 0.59 & 0.82 & 0.42 & 0.47 & - & 0.54 \\
\hline B & 20.9 & - & - & - & 33.0 & 32.0 & 11.0 & 16.0 & - & 17.0 \\
\hline $\mathrm{Sc}$ & 19 & 34 & 32 & 22 & 27 & 24 & 42 & 37 & 37 & 38 \\
\hline V & 191 & 279 & 287 & 234 & 252 & 239 & 285 & 282 & 309 & 319 \\
\hline $\mathrm{Cr}$ & 11 & 554 & 78 & 14 & 184 & 15 & 335 & 94 & 860 & 57 \\
\hline $\mathrm{Ni}$ & 7 & 174 & 18 & 4 & 78 & 10 & 57 & 20 & 316 & 13 \\
\hline $\mathrm{Cu}$ & 38 & 80 & 97 & 116 & 82 & 73 & 109 & 92 & 48 & 119 \\
\hline $\mathrm{Zn}$ & 66 & 75 & 68 & 99 & 66 & 62 & 59 & 69 & 79 & 67 \\
\hline $\mathrm{Ga}$ & 18.1 & 16.5 & 17.6 & 17.3 & 17.9 & 18.6 & 15.9 & 17.2 & 15.3 & 17.7 \\
\hline $\mathrm{Rb}$ & 21.85 & 3.97 & 11.16 & 25.09 & 33.37 & 37.89 & 10.80 & 11.41 & 7.32 & 13.13 \\
\hline $\mathrm{Sr}$ & 396 & 264 & 427 & 285 & 373 & 405 & 512 & 335 & 407 & 364 \\
\hline $\mathrm{Y}$ & 21.69 & 15.2 & 17.5 & 21.5 & 21.8 & 24.3 & 13.4 & 16.1 & 14.2 & 21.3 \\
\hline $\mathrm{Zr}$ & 102.2 & 63.2 & 64.3 & 111.3 & 106.2 & 121.4 & 44.4 & 43.8 & 51.7 & 74.2 \\
\hline $\mathrm{Nb}$ & 2.35 & 1.18 & 1.39 & 4.53 & 2.3 & 2.9 & 1.45 & 1.00 & 1.67 & 3.42 \\
\hline $\mathrm{Cs}$ & 1.07 & 0.00 & 0.36 & 1.30 & 2.07 & 2.38 & 0.72 & 0.91 & 0.10 & 0.85 \\
\hline $\mathrm{Ba}$ & 331 & 135 & 200 & 346 & 486 & 552 & 227 & 189 & 210 & 239 \\
\hline $\mathrm{La}$ & 8.85 & 4.10 & 7.29 & 8.82 & 9.12 & 10.10 & 3.98 & 3.95 & 6.62 & 5.84 \\
\hline $\mathrm{Ce}$ & 20.59 & 10.64 & 16.74 & 19.61 & 20.66 & 22.86 & 9.16 & 9.25 & 14.45 & 13.80 \\
\hline $\operatorname{Pr}$ & 3.02 & 1.70 & 2.49 & 2.73 & 2.99 & 3.37 & 1.42 & 1.40 & 2.12 & 2.08 \\
\hline $\mathrm{Nd}$ & 13.19 & 8.13 & 11.01 & 11.72 & 12.97 & 14.25 & 6.69 & 6.52 & 9.41 & 9.53 \\
\hline $\mathrm{Sm}$ & 3.52 & 2.52 & 2.90 & 3.14 & 3.49 & 3.84 & 2.05 & 1.99 & 2.41 & 2.91 \\
\hline $\mathrm{Eu}$ & 1.12 & 0.85 & 0.91 & 0.91 & 1.02 & 1.14 & 0.77 & 0.77 & 0.79 & 0.96 \\
\hline $\mathrm{Gd}$ & 3.50 & 2.69 & 2.92 & 3.24 & 3.44 & 3.94 & 2.20 & 2.37 & 2.43 & 3.31 \\
\hline $\mathrm{Tb}$ & 0.56 & 0.43 & 0.47 & 0.53 & 0.57 & 0.62 & 0.36 & 0.39 & 0.39 & 0.55 \\
\hline Dy & 3.49 & 2.62 & 2.92 & 3.35 & 3.55 & 3.87 & 2.20 & 2.55 & 2.35 & 3.37 \\
\hline Ho & 0.73 & 0.53 & 0.61 & 0.72 & 0.74 & 0.83 & 0.47 & 0.56 & 0.50 & 0.72 \\
\hline Er & 2.10 & 1.48 & 1.76 & 2.12 & 2.15 & 2.43 & 1.34 & 1.58 & 1.39 & 2.04 \\
\hline $\mathrm{Tm}$ & 0.34 & 0.23 & 0.28 & 0.35 & 0.34 & 0.38 & 0.20 & 0.25 & 0.21 & 0.31 \\
\hline $\mathrm{Yb}$ & 2.18 & 1.40 & 1.75 & 2.24 & 2.24 & 2.52 & 1.32 & 1.57 & 1.37 & 2.03 \\
\hline $\mathrm{Lu}$ & 0.36 & 0.22 & 0.28 & 0.37 & 0.37 & 0.41 & 0.21 & 0.25 & 0.22 & 0.32 \\
\hline Hf & 2.77 & 1.67 & 1.83 & 2.99 & 2.96 & 3.36 & 1.33 & 1.28 & 1.44 & 2.03 \\
\hline $\mathrm{Ta}$ & 0.19 & 0.09 & 0.11 & 1.93 & 0.19 & 0.17 & 0.10 & 0.10 & 0.11 & 0.26 \\
\hline $\mathrm{Pb}$ & 5.59 & 1.81 & 3.04 & 7.58 & 6.32 & 8.60 & 6.91 & 4.40 & 2.17 & 5.05 \\
\hline $\mathrm{U}$ & 0.936 & 0.231 & 0.576 & 1.097 & 1.456 & 1.663 & 0.617 & 0.512 & 0.594 & 0.579 \\
\hline $\mathrm{Th}$ & 1.936 & 0.423 & 1.291 & 2.458 & 2.564 & 3.497 & 1.078 & 0.900 & 1.338 & 1.174 \\
\hline${ }^{87} \mathrm{Sr} /{ }^{86} \mathrm{Sr}$ & 0.703230 & 0.703881 & 0.703256 & 0.703405 & 0.703340 & 0.703322 & 0.703364 & 0.703585 & 0.703020 & 0.703304 \\
\hline${ }^{143} \mathrm{Nd} /{ }^{144} \mathrm{Nd}$ & 0.513040 & 0.512978 & 0.513033 & 0.513030 & 0.513018 & 0.512956 & 0.512916 & 0.512967 & 0.513039 & 0.512987 \\
\hline${ }^{206} \mathrm{~Pb} /{ }^{204} \mathrm{~Pb}$ & 18.839 & 18.234 & 18.661 & 18.495 & 18.779 & 18.770 & 18.873 & 18.893 & 18.718 & 18.813 \\
\hline${ }^{207} \mathrm{~Pb} /{ }^{204} \mathrm{~Pb}$ & 15.595 & 15.493 & 15.540 & 15.562 & 15.544 & 15.529 & 15.561 & 15.583 & 15.539 & 15.533 \\
\hline${ }^{208} \mathrm{~Pb} /{ }^{204} \mathrm{~Pb}$ & 38.492 & 37.781 & 38.217 & 38.167 & 38.304 & 38.243 & 38.384 & 38.461 & 38.220 & 38.282 \\
\hline$\left({ }^{230} \mathrm{Th} /{ }^{232} \mathrm{Th}\right)$ & 1.338 & 1.405 & 1.667 & 1.339 & 1.265 & 1.243 & 1.288 & 1.309 & 1.318 & 1.286 \\
\hline$\left({ }^{226} \mathrm{Ra} /{ }^{230} \mathrm{Th}\right)$ & 1.057 & 1.177 & - & 1.001 & - & 1.373 & 2.147 & 1.123 & - & 1.351 \\
\hline${ }^{10} \mathrm{Be} /{ }^{9} \mathrm{Be}$ & 3.07 & - & - & - & - & 10.60 & 14.60 & 16.15 & - & 7.50 \\
\hline
\end{tabular}

$\mathrm{H}_{3} \mathrm{BO}_{4}$ to ensure sample spike equilibration and to eliminate fluorides. Anionic exchange resin was used to separate $\mathrm{U}$ from $\mathrm{Th}$ with $\mathrm{HNO}_{3}, \mathrm{HCl}$ and $\mathrm{HBr}$ as elutants, which were then loaded onto degassed, Re filaments using a $\mathrm{HNO}_{3}-\mathrm{H}_{3} \mathrm{PO}_{4}$ solution. Th and $\mathrm{U}$ concentrations and most ${ }^{230} \mathrm{Th} /{ }^{232} \mathrm{Th}$ isotope ratios were measured on a high abundance sensitivity, Finnegan MAT 262 mass spectrometer fitted with an RPQ II energy filter [van Calsteren and Schwieters, 1995]. Some ${ }^{230} \mathrm{Th} /{ }^{232} \mathrm{Th}$ measurements were made on a $\mathrm{Nu}$ instruments, multicollector ICP-MS using techniques reported by Turner et al. [2001a]. During the course of this work, the Open University internal Th "U" standard gave an average ${ }^{230} \mathrm{Th} /{ }^{232} \mathrm{Th}$ value of $6.129 \pm$ 0.057 (MAT 262) and $6.176 \pm 0.031 \times 10^{-6}(1 \sigma ; \mathrm{Nu})$. Replicate analyses of Th isotopes in the Kiska 1962 sample gave a mean of 7.207 and a standard deviation of 0.044 $(n=4)$. Three analyses of the TML standard gave a mean ${ }^{230} \mathrm{Th} /{ }^{232} \mathrm{Th}$ of $5.768 \pm 0.012 \times 10^{-6}(1 \sigma)$. Total proce- 
Table 1. (continued)

\begin{tabular}{|c|c|c|c|c|c|c|c|c|c|c|c|c|}
\hline & \multicolumn{12}{|c|}{ Sample } \\
\hline & Bogoslof & 96PN08 & AK81-35 & 96PS23 & NW95 1 & SAR-7 & $99 \mathrm{SH} 08$ & PAV-86 & 92CNA22 & NA94-5 & 94AMC 2 & UK-25B \\
\hline Volcano & Bogoslof & Makushin & Akutan & Akutan & Westdahl & Westdahl & Shishaldin & Pavlof & Aniakchak & Aniakchak & Aniakchak & Ukinrek \\
\hline Age & 1796 & historic & 1850 & 1978 & 1991 & active & 1999 & 1996 & $<1500 \mathrm{BC}$ & $<1500 \mathrm{BC}$ & $<1500 \mathrm{BC}$ & 1977 \\
\hline $\mathrm{SiO}_{2}$, wt $\%$ & 61.00 & 50.93 & 56.97 & 55.37 & 54.09 & 50.51 & 49.28 & 53.15 & 52.51 & 53.58 & 65.06 & 48.98 \\
\hline $\mathrm{TiO}_{2}$ & 0.53 & 0.82 & 1.06 & 1.15 & 1.72 & 1.46 & 2.09 & 1.05 & 1.17 & 1.20 & 0.94 & 1.05 \\
\hline $\mathrm{Al}_{2} \mathrm{O}_{3}$ & 18.60 & 16.81 & 18.19 & 17.06 & 15.72 & 17.52 & 17.96 & 19.88 & 18.10 & 18.07 & 15.98 & 16.90 \\
\hline $\mathrm{Fe}_{2} \mathrm{O}_{3} \mathrm{~T}$ & 4.70 & 10.02 & 8.84 & 10.56 & 11.99 & 12.25 & 12.54 & 8.91 & 10.44 & 9.66 & 5.26 & 10.75 \\
\hline $\mathrm{MnO}$ & 0.07 & 0.18 & 0.21 & 0.23 & 0.21 & 0.22 & 0.17 & 0.18 & 0.18 & 0.17 & 0.17 & \\
\hline $\mathrm{MgO}$ & 1.10 & 7.06 & 2.59 & 3.69 & 3.43 & 4.69 & 5.47 & 3.87 & 4.37 & 3.99 & 1.23 & 9.26 \\
\hline $\mathrm{CaO}$ & 6.50 & 11.29 & 7.43 & 7.65 & 7.41 & 9.53 & 9.19 & 9.20 & 10.10 & 9.52 & 3.79 & 9.79 \\
\hline $\mathrm{NaO}_{2}$ & 4.08 & 2.87 & 4.34 & 4.29 & 4.19 & 3.29 & 3.30 & 3.76 & 3.03 & 3.44 & 5.32 & 3.13 \\
\hline $\mathrm{K}_{2} \mathrm{O}$ & 2.90 & 0.88 & 0.94 & 0.86 & 1.22 & 0.81 & 0.72 & 0.63 & 0.94 & 1.10 & 2.48 & 0.82 \\
\hline $\mathrm{P}_{2} \mathrm{O}_{5}$ & 0.28 & 0.16 & 0.21 & 0.21 & 0.34 & 0.24 & 0.49 & 0.27 & 0.20 & 0.22 & 0.31 & 0.23 \\
\hline Total & 99.76 & 101.00 & 100.78 & 101.06 & 100.34 & 100.52 & 101.27 & 100.90 & 101.04 & 100.96 & 100.54 & 101.07 \\
\hline $\mathrm{Li}, \mathrm{ppm}$ & 13.0 & 7.4 & 13.5 & - & 12.0 & 9.1 & 7.4 & 7.1 & 12.4 & 11.1 & 23.2 & 6.5 \\
\hline $\mathrm{Be}$ & 2.6 & 0.36 & 0.89 & 0.57 & 0.99 & 0.93 & 0.82 & 0.61 & 1.07 & 0.61 & 1.35 & 0.42 \\
\hline B & 15.0 & 8.9 & - & 14.0 & 12.5 & 13.0 & 9.1 & 13.0 & 18.2 & 28.5 & 48.0 & 0.6 \\
\hline $\mathrm{Sc}$ & 5 & 39 & 20 & 27 & 31 & 39 & 28 & 22 & 32 & 31 & 14 & 30 \\
\hline $\mathrm{V}$ & 98 & 320 & 160 & 260 & 269 & 348 & 288 & 240 & 366 & 359 & 63 & 264 \\
\hline $\mathrm{Cr}$ & 4 & 212 & 2 & 7 & 5 & 15 & 2 & 13 & 39 & 73 & 143 & 366 \\
\hline $\mathrm{Ni}$ & 3 & 48 & 3 & 0 & 1 & 75 & 10 & 3 & 18 & 13 & 117 & 162 \\
\hline $\mathrm{Cu}$ & 6 & 102 & 53 & 108 & 49 & 88 & 68 & 36 & 91 & 76 & 12 & 61 \\
\hline $\mathrm{Zn}$ & 52 & 75 & 76 & 86 & 110 & 103 & 94 & 92 & 81 & 88 & 86 & 80 \\
\hline $\mathrm{Ga}$ & 21.9 & 17.7 & 18.9 & 19.2 & 21.4 & - & 18.0 & 20.3 & 19.2 & 19.8 & 19.4 & 18.8 \\
\hline $\mathrm{Rb}$ & 128.78 & 10.03 & 20.74 & 19.22 & 24.56 & 20.23 & 16.40 & 10.74 & 21.22 & 24.59 & 61.41 & 17.17 \\
\hline $\mathrm{Sr}$ & 776 & 595 & 407 & 370 & 387 & 366 & 548 & 427 & 372 & 422 & 300 & 518 \\
\hline Y & 21.1 & 17.3 & 34.3 & 32.9 & 40.6 & 28.9 & 37.3 & 26.2 & 24.3 & 26.8 & 45.7 & 21.5 \\
\hline $\mathrm{Zr}$ & 55.3 & 53.6 & 99.3 & 93.4 & 162.2 & 120.4 & 136.8 & 111 & 95.5 & 108.1 & 245.1 & 99.7 \\
\hline $\mathrm{Nb}$ & 8.04 & 1.77 & 4.57 & 1.8 & 6.39 & 4.97 & 6.75 & 3.86 & 5.72 & 6.37 & 14.77 & 4.83 \\
\hline Cs & 4.47 & 0.57 & 2.00 & 1.84 & 1.33 & 1.04 & 0.81 & 0.50 & 0.96 & 1.15 & 2.78 & 0.56 \\
\hline $\mathrm{Ba}$ & 1839 & 230 & 344 & 323 & 431 & 305 & 398 & 243 & 304 & 363 & 772 & 286 \\
\hline $\mathrm{La}$ & 25.10 & 6.99 & 7.86 & 7.61 & 13.42 & 10.29 & 15.15 & 8.31 & 9.80 & 11.87 & 23.49 & 10.82 \\
\hline $\mathrm{Ce}$ & 52.79 & 15.76 & 19.50 & 18.76 & 32.11 & 25.90 & 37.20 & 20.85 & 22.22 & 26.26 & 51.27 & 24.60 \\
\hline $\operatorname{Pr}$ & 7.09 & 2.31 & 3.01 & 2.91 & 4.95 & 3.95 & 5.70 & 3.17 & 3.17 & 3.75 & 7.08 & 3.57 \\
\hline $\mathrm{Nd}$ & 27.42 & 10.42 & 14.28 & 13.81 & 22.44 & 18.17 & 26.54 & 14.50 & 14.14 & 16.44 & 29.81 & 15.87 \\
\hline $\mathrm{Sm}$ & 5.59 & 2.76 & 4.45 & 4.38 & 6.35 & 4.88 & 7.00 & 4.05 & 3.93 & 4.42 & 7.66 & 4.13 \\
\hline $\mathrm{Eu}$ & 1.62 & 0.94 & 1.42 & 1.34 & 1.91 & 1.62 & 2.09 & 1.28 & 1.20 & 1.33 & 1.99 & 1.32 \\
\hline $\mathrm{Gd}$ & 4.65 & 2.75 & 5.17 & 5.01 & 6.66 & 5.53 & 7.04 & 4.23 & 4.12 & 4.45 & 7.56 & 4.07 \\
\hline $\mathrm{Tb}$ & 0.62 & 0.45 & 0.88 & 0.86 & 1.08 & 0.92 & 1.08 & 0.69 & 0.66 & 0.73 & 1.20 & 0.62 \\
\hline Dy & 3.56 & 2.77 & 5.57 & 5.37 & 6.60 & 5.66 & 6.45 & 4.32 & 4.11 & 4.51 & 7.47 & 3.64 \\
\hline Ho & 0.71 & 0.58 & 1.18 & 1.15 & 1.36 & 1.18 & 1.29 & 0.89 & 0.85 & 0.92 & 1.54 & 0.75 \\
\hline $\mathrm{Er}$ & 2.00 & 1.66 & 3.43 & 3.31 & 3.88 & 3.31 & 3.54 & 2.56 & 2.39 & 2.62 & 4.45 & 2.07 \\
\hline $\mathrm{Tm}$ & 0.31 & 0.26 & 0.53 & 0.52 & 0.60 & - & 0.52 & 0.40 & 0.36 & 0.40 & 0.69 & 0.32 \\
\hline $\mathrm{Yb}$ & 1.94 & 1.61 & 3.47 & 3.32 & 3.79 & 3.19 & 3.30 & 2.54 & 2.36 & 2.59 & 4.52 & 2.00 \\
\hline $\mathrm{Lu}$ & 0.29 & 0.26 & 0.54 & 0.53 & 0.60 & 0.50 & 0.50 & 0.40 & 0.37 & 0.42 & 0.72 & 0.31 \\
\hline $\mathrm{Hf}$ & 2.54 & 1.51 & 2.97 & 2.76 & 4.26 & 3.67 & 3.60 & 2.76 & 2.58 & 2.94 & 6.38 & 2.59 \\
\hline $\mathrm{Ta}$ & 1.28 & 0.13 & - & 0.14 & 0.63 & 0.35 & 0.46 & 0.63 & 0.62 & 0.41 & 0.95 & 0.43 \\
\hline $\mathrm{Pb}$ & 8.33 & 4.54 & 9.34 & 8.87 & 9.76 & 4.75 & 3.43 & 3.58 & 3.56 & 4.22 & 8.98 & 2.04 \\
\hline $\mathrm{U}$ & 2.112 & 0.707 & 0.979 & 0.900 & 1.252 & 0.830 & 0.808 & 0.448 & 0.898 & 1.066 & 2.571 & 0.579 \\
\hline Th & 4.814 & 1.445 & 1.779 & 1.673 & 2.763 & 1.930 & 1.257 & 0.816 & 1.914 & 2.202 & 4.649 & 1.529 \\
\hline${ }^{87} \mathrm{Sr} /{ }^{86} \mathrm{Sr}$ & 0.703140 & 0.703573 & 0.703577 & 0.703478 & 0.703091 & 0.703350 & 0.703016 & 0.703485 & 0.703272 & 0.703250 & 0.703359 & 0.703077 \\
\hline${ }^{143} \mathrm{Nd} /{ }^{144} \mathrm{Nd}$ & 0.512917 & 0.513017 & 0.513045 & 0.513001 & 0.513013 & 0.512926 & 0.513045 & 0.512962 & 0.512978 & 0.512984 & 0.512963 & 0.512971 \\
\hline${ }^{206} \mathrm{~Pb} /{ }^{204} \mathrm{~Pb}$ & 18.832 & 18.873 & 18.981 & 18.963 & 18.861 & 18.854 & 18.732 & 18.881 & 18.854 & 18.839 & 18.866 & 18.753 \\
\hline${ }^{207} \mathrm{~Pb} /{ }^{204} \mathrm{~Pb}$ & 15.566 & 15.582 & 15.602 & 15.591 & 15.565 & 15.555 & 15.523 & 15.573 & 15.565 & 15.559 & 15.565 & 15.549 \\
\hline${ }^{208} \mathrm{~Pb} /{ }^{204} \mathrm{~Pb}$ & 38.329 & 38.432 & 38.559 & 38.528 & 38.394 & 38.361 & 38.180 & 38.381 & 38.383 & 38.359 & 38.393 & 38.262 \\
\hline$\left({ }^{230} \mathrm{Th} /{ }^{232} \mathrm{Th}\right)$ & 1.292 & 1.414 & 1.348 & 1.324 & 1.313 & 1.313 & 1.509 & 1.440 & 1.457 & 1.350 & 1.411 & 1.304 \\
\hline$\left.{ }^{226} \mathrm{Ra}^{230} \mathrm{Th}\right)$ & 3.889 & - & - & 1.049 & 1.158 & - & 1.540 & 1.393 & - & - & - & 1.643 \\
\hline${ }^{10} \mathrm{Be} /{ }^{9} \mathrm{Be}$ & 9.00 & 8.61 & - & 7.88 & 5.90 & 6.10 & 2.52 & - & 11.75 & 0.43 & 0.43 & 0.18 \\
\hline
\end{tabular}

dural blanks were $<50 \mathrm{pg}$ for both $\mathrm{U}$ and Th. $\left({ }^{234} \mathrm{U} /{ }^{238} \mathrm{U}\right)$ ratios (not reported) in all samples are within error of unity, suggesting that subsolidus (seawater) alteration has not modified the primary lava compositions. Our analysis of sample UK-25b from the 1977 eruption of the Ukinrek Maars falls within analytical certainty of alpha spectrometry data reported by Newman et al. [1984] for the same lava.

[14] Ra was separated from samples with known historic eruption ages (erupted from 1796 to 1999 A.D.). Samples marked with a dash in Table 1 were not analyzed. Powders were weighed to yield $\sim 50$ fg of $\mathrm{Ra}$, and spiked with ${ }^{228} \mathrm{Ra}$ to achieve a ${ }^{228} \mathrm{Ra} /{ }^{226} \mathrm{Ra}$ ratio of $\sim 1$. Ra was preconcentrated from the elutant collected from the anionic columns used for U-Th separation using a double pass through cation exchange resin, using $\mathrm{HCl}, \mathrm{H}_{2} \mathrm{O}$, and $\mathrm{HNO}_{3}$ as elutants. $\mathrm{Ra}$ and $\mathrm{Ba}$ were separated by chromatographic separation using ElChrom Sr spec resin ${ }^{(0)}$ and $\mathrm{HNO}_{3}$ as the elutant. Samples were loaded onto degassed Re filaments with a Ta-HF$\mathrm{H}_{3} \mathrm{PO}_{4}$ activator solution. Samples were analyzed dynam- 
Table 1. (continued)

\begin{tabular}{|c|c|c|c|c|c|c|c|c|c|}
\hline & \multicolumn{9}{|c|}{ Sample } \\
\hline & 97NT18 & 97NT28 & 97ND02 & 89A16B & RDSS-3 & 90CNR12 & $85 \mathrm{CNS} 17$ & 92JBS02 & $\mathrm{CN}$ BC 01 \\
\hline Volcano & Trident & Trident & Katmai & Augustine & Redoubt & Redoubt & Spurr & Spurr & Buzzard Creek \\
\hline Age & $1953-1963$ & $1953-1963$ & 1912 & $<500 \mathrm{BC}$ & $1989-90$ & $1989-90$ & 1953 & 1992 & $1000 \mathrm{BC}$ \\
\hline $\mathrm{SiO}_{2}$, wt $\%$ & 56.87 & 65.03 & 55.16 & 63.08 & 58.18 & 63.44 & 54.89 & 56.64 & 54.01 \\
\hline $\mathrm{TiO}_{2}$ & 0.81 & 0.65 & 0.83 & 0.55 & 0.62 & 0.46 & 0.86 & 0.68 & 0.82 \\
\hline $\mathrm{Al}_{2} \mathrm{O}_{3}$ & 17.77 & 15.97 & 17.31 & 16.60 & 18.80 & 17.67 & 18.80 & 19.08 & 14.40 \\
\hline $\mathrm{Fe}_{2} \mathrm{O}_{3} \mathrm{~T}$ & 7.77 & 5.45 & 9.57 & 5.77 & 7.23 & 5.20 & 8.54 & 7.81 & 8.21 \\
\hline $\mathrm{MnO}$ & 0.15 & 0.12 & 0.15 & 0.12 & 0.15 & 0.13 & 0.15 & 0.15 & 0.13 \\
\hline $\mathrm{MgO}$ & 8.50 & 5.02 & 9.20 & 3.19 & 2.65 & 1.77 & 4.58 & 3.58 & 9.39 \\
\hline $\mathrm{CaO}$ & 4.33 & 2.17 & 4.83 & 6.27 & 7.58 & 5.80 & 8.02 & 7.59 & 8.55 \\
\hline $\mathrm{NaO}_{2}$ & 3.49 & 4.36 & 2.92 & 3.88 & 3.96 & 4.18 & 3.81 & 4.06 & 2.18 \\
\hline $\mathrm{K}_{2} \mathrm{O}$ & 0.95 & 1.64 & 0.86 & 0.98 & 1.31 & 1.68 & 0.95 & 0.87 & 1.71 \\
\hline $\mathrm{P}_{2} \mathrm{O}_{5}$ & 0.14 & 0.14 & 0.14 & 0.13 & 0.23 & 0.19 & 0.26 & 0.29 & 0.16 \\
\hline Total & 100.78 & 100.54 & 100.97 & 100.58 & 100.71 & 100.52 & 100.86 & 100.75 & 99.57 \\
\hline $\mathrm{Li}, \mathrm{ppm}$ & 23.1 & 21.0 & 11.5 & 10.0 & 11.1 & 18.1 & 13.6 & 14.2 & \\
\hline $\mathrm{Be}$ & 0.61 & 0.87 & 0.78 & 0.49 & 0.74 & 0.79 & 0.83 & 0.8 & \\
\hline B & 13.0 & 0.6 & 11.0 & - & - & - & 11.0 & 2.7 & \\
\hline $\mathrm{Sc}$ & 27 & 17 & 32 & 20 & 11 & 4 & 21 & 12 & 25 \\
\hline V & 248 & 124 & 283 & 181 & 164 & 93 & 248 & 171 & 212 \\
\hline $\mathrm{Cr}$ & 55 & 15 & 30 & 162 & 4 & 2 & 50 & 38 & 555 \\
\hline $\mathrm{Ni}$ & 15 & 7 & 4 & 27 & 6 & 0 & 29 & 26 & 183 \\
\hline $\mathrm{Cu}$ & 38 & 16 & 18 & 36 & 43 & 26 & 73 & 50 & 18 \\
\hline $\mathrm{Zn}$ & 73 & 61 & 76 & 55 & 76 & 72 & 111 & 86 & 52 \\
\hline $\mathrm{Ga}$ & 18.4 & 16.9 & 18.5 & 16.7 & 20.6 & 16.6 & 21.3 & 20.6 & 15.9 \\
\hline $\mathrm{Rb}$ & 18.32 & 33.01 & 17.19 & 15.22 & 25.83 & 31.63 & 18.07 & 13.29 & 38.03 \\
\hline $\mathrm{Sr}$ & 364 & 257 & 361 & 306 & 554 & 449 & 745 & 669 & 475 \\
\hline Y & 22.2 & 31.1 & 20.4 & 19.9 & 18.4 & 14.2 & 18.5 & 16.6 & 19.7 \\
\hline $\mathrm{Zr}$ & 89.3 & 152.1 & 78.6 & 98.6 & 106.7 & 79.5 & 92.5 & 89.9 & 60.6 \\
\hline $\mathrm{Nb}$ & 2.39 & 3.91 & 2.25 & 2.62 & 5.26 & 5.18 & 5.1 & 4.78 & 9.05 \\
\hline Cs & 0.75 & 1.28 & 0.70 & 0.34 & 0.87 & 1.17 & 0.60 & 0.39 & 0.50 \\
\hline $\mathrm{Ba}$ & 332 & 549 & 304 & 372 & 562 & 660 & 401 & 405 & 640 \\
\hline $\mathrm{La}$ & 7.90 & 11.67 & 7.11 & 8.82 & 11.20 & 10.95 & 12.02 & 10.58 & 15.03 \\
\hline $\mathrm{Ce}$ & 17.96 & 26.30 & 16.25 & 19.43 & 24.23 & 22.83 & 26.93 & 23.59 & 31.14 \\
\hline $\operatorname{Pr}$ & 2.64 & 3.77 & 2.41 & 2.71 & 3.29 & 2.92 & 3.78 & 3.28 & 3.88 \\
\hline $\mathrm{Nd}$ & 11.82 & 16.27 & 10.82 & 11.58 & 13.76 & 11.52 & 16.45 & 14.07 & 15.34 \\
\hline Sm & 3.34 & 4.47 & 3.09 & 3.01 & 3.41 & 2.61 & 3.92 & 3.34 & 3.55 \\
\hline $\mathrm{Eu}$ & 1.01 & 1.14 & 0.92 & 0.89 & 1.04 & 0.80 & 1.25 & 1.11 & 0.96 \\
\hline $\mathrm{Gd}$ & 3.52 & 4.58 & 3.23 & 3.06 & 3.27 & 2.41 & 3.56 & 3.20 & 3.50 \\
\hline $\mathrm{Tb}$ & 0.58 & 0.76 & 0.53 & 0.50 & 0.50 & 0.38 & 0.55 & 0.48 & 0.56 \\
\hline Dy & 3.67 & 4.86 & 3.35 & 3.16 & 3.01 & 2.23 & 3.17 & 2.84 & 3.40 \\
\hline Ho & 0.76 & 1.05 & 0.71 & 0.67 & 0.62 & 0.46 & 0.63 & 0.58 & 0.68 \\
\hline $\mathrm{Er}$ & 2.19 & 3.06 & 2.03 & 1.96 & 1.78 & 1.31 & 1.75 & 1.61 & 1.88 \\
\hline $\mathrm{Tm}$ & 0.34 & 0.49 & 0.32 & 0.32 & 0.28 & 0.21 & 0.27 & 0.26 & 0.28 \\
\hline $\mathrm{Yb}$ & 2.23 & 3.21 & 2.04 & 2.09 & 1.85 & 1.44 & 1.70 & 1.65 & 1.78 \\
\hline $\mathrm{Lu}$ & 0.36 & 0.52 & 0.32 & 0.35 & 0.30 & 0.23 & 0.27 & 0.26 & 0.27 \\
\hline $\mathrm{Hf}$ & 2.52 & 4.16 & 2.27 & 2.72 & 2.86 & 2.26 & 2.44 & 2.37 & 1.77 \\
\hline $\mathrm{Ta}$ & 0.29 & 0.43 & 0.59 & 0.19 & 0.34 & 0.37 & 0.28 & 0.26 & 0.57 \\
\hline $\mathrm{Pb}$ & 4.37 & 6.41 & 3.68 & 2.11 & 5.09 & 5.55 & 4.42 & 4.55 & 4.64 \\
\hline U & 0.843 & 1.381 & 0.699 & 0.740 & 0.355 & 0.754 & 0.349 & 0.250 & 1.270 \\
\hline Th & 1.797 & 2.845 & 1.642 & 1.656 & 1.390 & 1.826 & 1.430 & 0.872 & 3.660 \\
\hline${ }^{87} \mathrm{Sr} /{ }^{86} \mathrm{Sr}$ & 0.703524 & 0.703559 & 0.703475 & 0.703345 & 0.703603 & 0.703595 & 0.703697 & 0.703656 & 0.705168 \\
\hline${ }^{143} \mathrm{Nd} / /^{144} \mathrm{Nd}$ & 0.512952 & 0.512967 & 0.512952 & 0.513033 & 0.512924 & 0.513001 & 0.512868 & 0.512868 & 0.512501 \\
\hline${ }^{206} \mathrm{~Pb} /{ }^{204} \mathrm{~Pb}$ & 18.862 & 18.859 & 18.879 & 18.845 & 18.768 & 18.752 & 18.833 & 18.782 & 19.208 \\
\hline${ }^{207} \mathrm{~Pb} /{ }^{204} \mathrm{~Pb}$ & 15.580 & 15.571 & 15.581 & 15.566 & 15.557 & 15.555 & 15.573 & 15.564 & 15.660 \\
\hline${ }^{208} \mathrm{~Pb} /{ }^{204} \mathrm{~Pb}$ & 38.378 & 38.363 & 38.393 & 38.345 & 38.311 & 38.291 & 38.421 & 38.360 & 39.102 \\
\hline$\left({ }^{230} \mathrm{Th} /{ }^{232} \mathrm{Th}\right)$ & 1.368 & 1.433 & 1.387 & 1.532 & 1.306 & 1.303 & 1.312 & 1.161 & 0.800 \\
\hline$\left({ }^{226} \mathrm{Ra} /{ }^{230} \mathrm{Th}\right)$ & 1.176 & 0.996 & 1.086 & - & 1.154 & 1.141 & 1.177 & 1.366 & \\
\hline${ }^{10} \mathrm{Be}^{/ 9} \mathrm{Be}$ & - & 0.10 & - & - & - & 0.11 & - & 0.09 & \\
\hline
\end{tabular}

ically on the Finnegan MAT 262-RPQII-SEM at the Open University. Analytical precision was better than $1 \%(2 \sigma)$. Repeat analyses of a sample from Mount Lassen and an inhouse standard (ThITS) were used to assess the accuracy and reproducibility of the analyses which is estimated to be $\sim 1.3 \%$ for $\left({ }^{226} \mathrm{Ra} /{ }^{230} \mathrm{Th}\right)$ ratios [Turner et al., 2000]. Total procedural blanks were below detection limits $\left(<0.1 \mathrm{fg} \mathrm{g}^{-1}\right)$. Throughout this paper, we use brackets to denote activity ratios and the decay constants used in the calculation of activity ratios and for age correcting the ${ }^{226} \mathrm{Ra}$ data were $\lambda^{230} \mathrm{Th}=9.1952 \times 10^{-6}, \lambda^{232} \mathrm{Th}=4.948 \times 10^{-11} ; \lambda^{238} \mathrm{U}=$ $1.551 \times 10^{-10} ; \lambda^{226} \mathrm{Ra}=4.332 \times 10^{-4}$.

\subsection{Be Isotopes}

[15] The ${ }^{10}$ Be separations were carried out at Washington University from a carefully chosen subset of samples which were of well-constrained age as well as being visibly fresh. Outer surfaces were removed from large hand specimens to a depth of $>1 \mathrm{~cm}$. Samples were then chipped and prehistoric samples were carefully leached in $1 \mathrm{~N} \mathrm{HCl}$ for 1 hour 
in an ultrasonic bath, to identify mobile ${ }^{10} \mathrm{Be}$ that may have resulted from surface alteration. Rock samples and leachates then underwent spiking and chemical separation using techniques described by Tera et al. [1986]. The ${ }^{10} \mathrm{Be}$ concentrations were determined by accelerator mass spectrometry at the Lawrence Livermore center for mass spectrometry. Errors on ${ }^{10} \mathrm{Be}$ measurements are typically $5 \%$ $(1 \sigma)$ at concentrations $>1 \times 10^{-6}$ atoms per gram. (hereinafter denoted as atoms $\mathrm{g}^{-1}$ ). A minor amount of leachable ${ }^{10} \mathrm{Be}(15 \%$ of total) was found in the Makushin lava (96PN08), whereas Seguam (99SJP01) and a precaldera Aniakchak sample (92CNA11) contained significant leachable ${ }^{10} \mathrm{Be}$, with leachable ${ }^{10} \mathrm{Be}$ being $\sim 50 \%$ of total for the Seguam sample and about $100 \%$ of the low amount of the Aniakchak lava. All others had negligible leachable ${ }^{10} \mathrm{Be}$. Total chemistry blanks for rock samples were $<0.02 \times 10^{6}$ atoms $\mathrm{g}^{-1} \pm 50 \%$ and $<0.05 \times 10^{6}$ atoms $\mathrm{g}^{-1}$ for leachates. A detection limit of $0.1 \times 10^{6}$ atoms $\mathrm{g}^{-1}$ for the volcanic samples has been adopted.

\section{Results}

[16] The complete major, trace element, $\mathrm{Sr}, \mathrm{Nd}, \mathrm{Pb}, \mathrm{U}-$ $\mathrm{Th}-\mathrm{Ra}$, and $\mathrm{Be}$ isotope data set for the lavas is presented in Table 1, while Be isotope and $\mathrm{B}$ concentration data for the sediments are presented in Table 2 .

\subsection{Major and Trace Elements}

[17] The lavas have been subdivided according to their position along the arc with samples erupted through continental crust (Alaska) marked with open symbols and those erupted through oceanic crust (Aleutians) with solid symbols (Figure 1). Most of the samples are basalts and basaltic andesites (Figure 3), and they are from both the tholeiitic and calc-alkaline rock series according to the $\mathrm{SiO}_{2}-\mathrm{FeO} /$ $\mathrm{MgO}$ diagram. The two Redoubt samples (RDSS-3 and 90CNR12), Bogoslof (BOG 1796), and the Little Sitkin sample (52-496) are andesites. Sample 97NT18 is an andesitic enclave in a dacitic host lava (97NT28) from the 1964 New Trident eruption reported by Coombs et al. [2001]. One of the Aniakchak samples (94AMC2) is also a dacite.

[18] $\mathrm{Mg}$ numbers $\left(\mathrm{Mg} \#=\left(\mathrm{Mg}^{2+} /\left(\mathrm{Mg}^{2+}+\mathrm{Fe}^{2+}\right)\right)^{*} 100\right)$ cover a similar range in both Alaskan and Aleutian lavas (35 to 72 ). $\mathrm{K}_{2} \mathrm{O}-\mathrm{SiO}_{2}$ variations (Figure 3) show that the bulk compositions of both suites are broadly similar, but on average, the Alaskan samples have higher silica contents. Most of the data lie at the less evolved end of the arc-wide published database (see Figure 3 caption for data sources), and they also have lower silica contents than the high $\mathrm{Mg}$ number andesites erupted at Piip and the Komandorskys in the west [Yogodzinski et al., 1995]. $\mathrm{CaO} / \mathrm{Al}_{2} \mathrm{O}_{3}$ ratios range from 0.13 to 0.79 , although some volcanoes lying on continental crust (e.g., Shishaldin, Ukinrek, Katmai, Augustine) show trends of sharply decreasing $\mathrm{CaO}$ as $\mathrm{MgO}$ decreases, with consequently low $\mathrm{CaO} / \mathrm{Al}_{2} \mathrm{O}_{3}$ ratios. $\mathrm{CaO}$ / $\mathrm{TiO}_{2}$ ratios are sensitive to, and increase with, the degree of wedge depletion (in rocks that are primitive enough not to have crystallized magnetite) [Falloon et al., 1988; Turner and Hawkesworth, 1995]. In the Aleutian-Alaska data, $\mathrm{CaO} / \mathrm{TiO}_{2}$ ratios show a moderate increase from an average of 8 in Alaska to 13 in the Aleutians in samples with $<56 \mathrm{wt} \% \mathrm{SiO}_{2}$.
Table 2. B and Be Concentrations and Ratios for Aleutian Sediments

\begin{tabular}{|c|c|c|c|c|c|}
\hline Sample ID ${ }^{\mathrm{a}}$ & $\begin{array}{c}\text { Depth, } \\
\text { mbsf }\end{array}$ & $\begin{array}{r}{ }^{10} \mathrm{Be}, 10^{6} \\
\text { atoms } / \mathrm{g}\end{array}$ & ${ }^{9} \mathrm{Be}, \mathrm{ppm}$ & $\mathrm{B}, \mathrm{ppm}$ & $\mathrm{B} / \mathrm{Be}$ \\
\hline \multicolumn{6}{|l|}{ DSDP 183} \\
\hline $1-2,140-141$ & 2.9 & 864 & 1.14 & 98 & 86.0 \\
\hline $2-3,54-55$ & 6.5 & 1588 & 1.18 & 64.1 & 54.3 \\
\hline $3-1,90-91$ & 12.9 & 932 & 1.08 & 86.5 & 80.1 \\
\hline $4-2,93-94$ & 23.4 & 1058 & 1.32 & 71 & 53.8 \\
\hline $4-4,37-38$ & 25.9 & 280 & 1.31 & 25.1 & 19.2 \\
\hline $5-3,70-71$ & 33.7 & 1071 & 1.18 & 95.1 & 80.6 \\
\hline $5-4,70-71$ & 35.2 & 1223 & 1.28 & 65.8 & 51.4 \\
\hline $6-1,142-143$ & 41.5 & 703 & 1.17 & 65.7 & 56.2 \\
\hline $6-4,18-19$ & 46.2 & 603 & 1.18 & 59.3 & 50.3 \\
\hline $7-2,115-116$ & 51.6 & 2024 & 1.21 & 78 & 64.5 \\
\hline $8-1,93-94$ & 59.9 & 1112 & 1.42 & 66.2 & 46.6 \\
\hline $8-3,135-136$ & 63.4 & 823 & 1.14 & 64.4 & 56.5 \\
\hline $9-5,65-67$ & 73.2 & 1084 & 0.67 & 109 & 162.7 \\
\hline $10-2,79-80$ & 80.3 & 1025 & 0.67 & 96.3 & 143.7 \\
\hline $11-2,122-123$ & 101.7 & 736 & 1.21 & 66.7 & 55.1 \\
\hline $12-3,76-77$ & 121.8 & 779 & 1.05 & 45.1 & 43.0 \\
\hline $13-4,74-75$ & 132.3 & 356 & 1.13 & 52.3 & 46.3 \\
\hline $15-5,122-123$ & 153.2 & 266 & 1.03 & 42.4 & 41.2 \\
\hline $17-3,144-145$ & 168.5 & 100 & 0.68 & 65.5 & 96.3 \\
\hline $19-1,117-118$ & 184.2 & 47 & 1.1 & 62 & 56.4 \\
\hline $21-2,93-94$ & 203.4 & 235 & 1.65 & 64.5 & 39.1 \\
\hline $22-1,130-131$ & 211.3 & 85 & 1.32 & 87.1 & 66.0 \\
\hline $23-1,86-87$ & 220.8 & 0 & 1.38 & 79.7 & 57.8 \\
\hline \multicolumn{6}{|l|}{ DSDP 186} \\
\hline $2-1,75-76$ & 2.7 & 712 & 1.09 & 61.5 & 56.4 \\
\hline $2-2,57-58$ & 5.6 & 1624 & 0.98 & 77 & 78.6 \\
\hline $3-2,75-76$ & 14.8 & 1110 & 1.16 & 59.8 & 51.6 \\
\hline $3-2,115-116$ & 15.2 & 468.2 & 1.07 & 55.6 & 52.0 \\
\hline $4-1,75-76$ & 49.8 & 923 & 1.11 & 80.4 & 72.4 \\
\hline $4-3,103-104$ & 53 & 1147 & 1.23 & 97.4 & 79.2 \\
\hline $5-1,121-122$ & 97.2 & 622 & 1.14 & 31.8 & 27.9 \\
\hline $6-3,70-71$ & 108.7 & 740.1 & 1.11 & 49.2 & 44.3 \\
\hline $7-1,118-119$ & 115.4 & 93.1 & 0.84 & 16.7 & 19.9 \\
\hline $7-1,143-144$ & 115.4 & 424 & 1.01 & 53.4 & 52.9 \\
\hline $8-5,100-101$ & 140 & 328.7 & 1.27 & 64.2 & 50.6 \\
\hline $10-4,76-77$ & 175.2 & 783 & 1.23 & 67.1 & 54.6 \\
\hline $12-1,100-101$ & 246.2 & 530.4 & 1.06 & 71.1 & 67.1 \\
\hline $13-2,23-24$ & 292.7 & 283.1 & 1.14 & 64.3 & 56.4 \\
\hline $14-1,120-121$ & 339.9 & 314.6 & 1.01 & 58.2 & 57.6 \\
\hline $16-1,92-93$ & 394.9 & 0.1 & 0.96 & 55.5 & 57.8 \\
\hline $18-1,100-101$ & 441 & 222.3 & 1.1 & 48.1 & 43.7 \\
\hline $18-1,86-87$ & 440.8 & 158.1 & 1.06 & 66.7 & 62.9 \\
\hline $21-1,100-101$ & 507 & 265.8 & 1.13 & 67.3 & 59.6 \\
\hline $22-3,104-105$ & 566 & 63.9 & 0.97 & 54.2 & 55.9 \\
\hline $22-3,124-125$ & 566 & 57 & 0.96 & 42.6 & 44.4 \\
\hline $22-3,145-146$ & 566 & 36.3 & 0.9 & 45.2 & 50.2 \\
\hline $23-3,110-111$ & 622.1 & 7.5 & 1 & 88.1 & 88.1 \\
\hline $24-1,80-81$ & 683.8 & 146.1 & 1.1 & 59.9 & 54.5 \\
\hline $25-1,80-81$ & 731.8 & 110.2 & 1.23 & 70.3 & 57.2 \\
\hline $26-1,100-101$ & 806 & 281.4 & 0.97 & 73.9 & 76.2 \\
\hline $27-1,85-86$ & 861.8 & 60.9 & 1.2 & 61.2 & 51.0 \\
\hline $28-1,112-113$ & 918.1 & 94 & 1 & 61.2 & 61.2 \\
\hline
\end{tabular}

[19] Normalized trace element patterns for the most mafic samples from Alaskan and Aleutian parts of the arc are plotted in Figures $4 \mathrm{a}$ and $4 \mathrm{~b}$, as are the two weighted mean compositions of Aleutian sediments from Plank and Langmuir [1998]. The patterns are typical of island arc lavas, with characteristic large ion lithophile element (LILE) enrichments and high field strength element (HFSE) depletions relative to mid-ocean ridge basalts (MORB) [Sun and McDonough, 1989]. One striking discriminant between oceanic Aleutian and continental Alaskan lavas is their $\mathrm{Nb}$ (and Ta) concentrations (Figure 4b). In the least differ- 


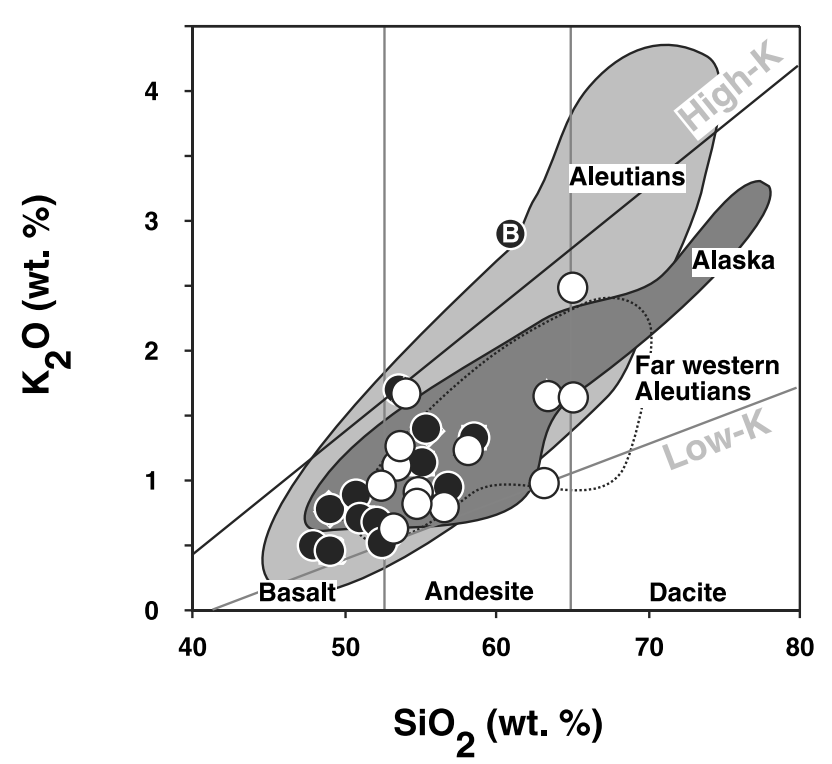

Figure 3. $\mathrm{K}_{2} \mathrm{O}-\mathrm{SiO}_{2}$ variations in Alaskan (open circles) and Aleutian lavas (solid circles). These are compared with Aleutian-Alaskan data from Nye and Reid [1986], Miller et al. [1994], Class et al. [2000], Romick et al. [1990], Hildreth [1983], Johnson et al. [1996], Nye and Turner [1990], Nye et al. [1994], Kay and Kay [1994], and J. Myers and T. McElfrish (unpublished data compilation); as well as samples from the Piip and Komandorsky block [Yogodzinski et al., 1994, 1995]. The back-arc Bogoslof sample (B) is distinguished by its high $\mathrm{K}_{2} \mathrm{O}$ content. All others lie within the medium-K field of Le Maitre et al. [1989]. Alaskan samples extend to more evolved compositions than the relatively restricted range of the Aleutian data.

entiated samples (below $56 \mathrm{wt} \% \mathrm{SiO}_{2}$ ), $\mathrm{Nb}$ ranges from 1 to $3.4 \mathrm{ppm}$ in the Aleutian basalts, while in Alaskan rocks it ranges from 3.8 to $9 \mathrm{ppm}$. This is in part a reflection of the fact that the Aleutian rocks have lower abundances in many trace elements, consistent with their higher $\mathrm{CaO} / \mathrm{TiO}{ }_{2}$ ratios, but one consequence is that they have, for example, higher LIL/HFSE and $\mathrm{Th} / \mathrm{Nb}$ ratios $(0.3-1.2$ in the Aleutians, $0.18-0.75$ in Alaska) which is a feature of more depleted arc compositions [e.g., Gill, 1981; Elliott et al., 1997; Turner et al., 1997]. The lavas are moderately enriched in light rare earth elements (REE) and possess negative Ce anomalies with $\mathrm{Ce} / \mathrm{Ce}^{*}$ ranging from 0.99 to 0.94 . The Shishaldin sample shows higher absolute middle REE abundances without corresponding LILE enrichment, despite its undifferentiated bulk composition $\left(\mathrm{SiO}_{2}=49\right.$ $\mathrm{wt} \%$ ). The trace element profiles of the two bulk sediment compositions are similar (Figure 4), except for greater LILE enrichments in DSDP 183 which is west of DSDP 178 (Figure 1).

\subsection{Radiogenic Isotopes}

[20] Isotopically, the samples overlap with published analyses for the Alaska-Aleutian arc (Figure 5) [McCulloch and Perfit, 1981; Morris and Hart, 1983; Von Drach et al., 1986; Singer et al., 1992; Miller et al., 1994; Class et al., 2000; Yogodzinski et al., 1994; 1995; Kelemen et al., 2003; J. Myers and T. McElfrish, unpublished data compilation]. In diagrams plotted here, we have only used published analyses for samples with $<56 \% \mathrm{SiO}_{2}$, and which are less than $5 \mathrm{Ma}$, to aid comparison with the young samples of this study and to highlight variations that may reflect mantle processes. The ${ }^{87} \mathrm{Sr} /{ }^{86} \mathrm{Sr}$ compositions in the Aleutian samples range from 0.7030 to 0.7039 and are similar to those in the Alaskan suite (0.7030-0.7037), with the exception of the Buzzard Creek maar lava which has a comparatively high ${ }^{87} \mathrm{Sr} /{ }^{86} \mathrm{Sr}$ ratio of 0.7051 . The ${ }^{143} \mathrm{Nd} /{ }^{144} \mathrm{Nd}$ compositions are also similar in both the Aleutian (0.51292-0.51305) and Alaskan rocks $(0.51287-0.51305)$ with the exception of Buzzard Creek that has a ${ }^{143} \mathrm{Nd} /{ }^{144} \mathrm{Nd}$ of 0.51250 . The lavas lie broadly between the MORB and sediment fields whereas data reported from Piip and the Komandorsky islands [Yogodzinski et al., 1995] in the far western Aleutians overlap the MORB field (Figure 5). The $\mathrm{Pb}$ isotope ratios $\left({ }^{206} \mathrm{~Pb} /{ }^{204} \mathrm{~Pb}=18.2-19.1\right.$ in Aleutian lavas, and $18.7-19.3$ in their Alaskan counterparts) lie between those reported for Pacific MORB and Alaska-Aleutian sediments (Figure 5). In $\mathrm{Pb}$ isotope space the Piip and the Komandorsky lavas are again distinct, having much less radiogenic $\mathrm{Pb}$ [Yogodzinski et al., 1995].

\subsection{Uranium, Thorium, and Radium Isotopes}

[21] U-Th disequilibria extend from modest Th excesses of 30\% to more typical and larger, 75\% U excesses (Figure 6a). Overall, $\left({ }^{230} \mathrm{Th} /{ }^{232} \mathrm{Th}\right)$ ranges from 0.8 to 1.7 but it is notable that many of the oceanic Aleutian lavas have Th isotope ratios that are similar to, and rarely lower than, the average sediment from DSDP Site 183 (Figure 6a) which has a $\left({ }^{230} \mathrm{Th} /{ }^{232} \mathrm{Th}\right)$ ratio of 1.3 (calculated from bulk sediment U/Th ratio [Plank and Langmuir, 1998]). The average $\left({ }^{230} \mathrm{Th} /{ }^{232} \mathrm{Th}\right)$ of Pacific MORB calculated from $\kappa_{\mathrm{Pb}}$ values is also 1.3 [Sun, 1980; Ben Othman et al., 1989; McDermott and Hawkesworth, 1991]. Finally, the back-arc Bogoslof sample has a near-equilibrium composition at a $\left({ }^{230} \mathrm{Th} /{ }^{232} \mathrm{Th}\right)$ ratio of 1.29 .

[22] Compared with the Aleutian lavas, most of the continental Alaskan lavas are displaced to higher $\left({ }^{230} \mathrm{Th} /{ }^{232} \mathrm{Th}\right)$ than the DSDP 183 sediments and Pacific MORB, and the lower silica continental rocks form a weakly correlated, inclined array that straddles the equiline (Figure 6a). More evolved lavas from the easternmost Alaskan volcanoes (Spurr and Redoubt) have some of the lowest $\left({ }^{230} \mathrm{Th} /{ }^{232} \mathrm{Th}\right.$ ) ratios and are positioned on both sides of the equiline $\left(\left({ }^{230} \mathrm{Th} /{ }^{232} \mathrm{Th}\right)=1.16-1.31\right)$. The Buzzard Creek rock is again distinct from the other lavas in having a very low $\left({ }^{230} \mathrm{Th} /{ }^{232} \mathrm{Th}\right)$. This is similar to the activity ratio of bulk continental crust calculated from average crustal U/Th ratios [Taylor and McLennan, 1985].

[23] The Aleutian samples preserve modest $\left({ }^{226} \mathrm{Ra} /{ }^{230} \mathrm{Th}\right)$ excesses up to $110 \%$ (Figure 6b), although Bogoslof is notable for its extreme ${ }^{226} \mathrm{Ra}$ enrichment $(300 \%)$, and falls outside of the scale of Figure $6 \mathrm{~b}$. The ${ }^{226} \mathrm{Ra}$ excesses occur throughout both oceanic and continental suites, and are not well correlated with ${ }^{238} \mathrm{U}^{230} \mathrm{Th}$ disequilibria (Figure $6 \mathrm{~b}$ ). As shown elsewhere, these ${ }^{226} \mathrm{Ra}$ excesses are unlikely to result from seawater alteration [Turner et al., 2000]. $\mathrm{D}_{\mathrm{Ra}}$ in plagioclase is $\sim 0.09$ (J. Blundy, personal communication, 2002 ), and analyzed arc plagioclases typically have $<10 \mathrm{fg}$ $\mathrm{g}^{-1226} \mathrm{Ra}$ (R. George and S. Turner, unpublished data, 2002) compared with several hundred femtograms per gram 


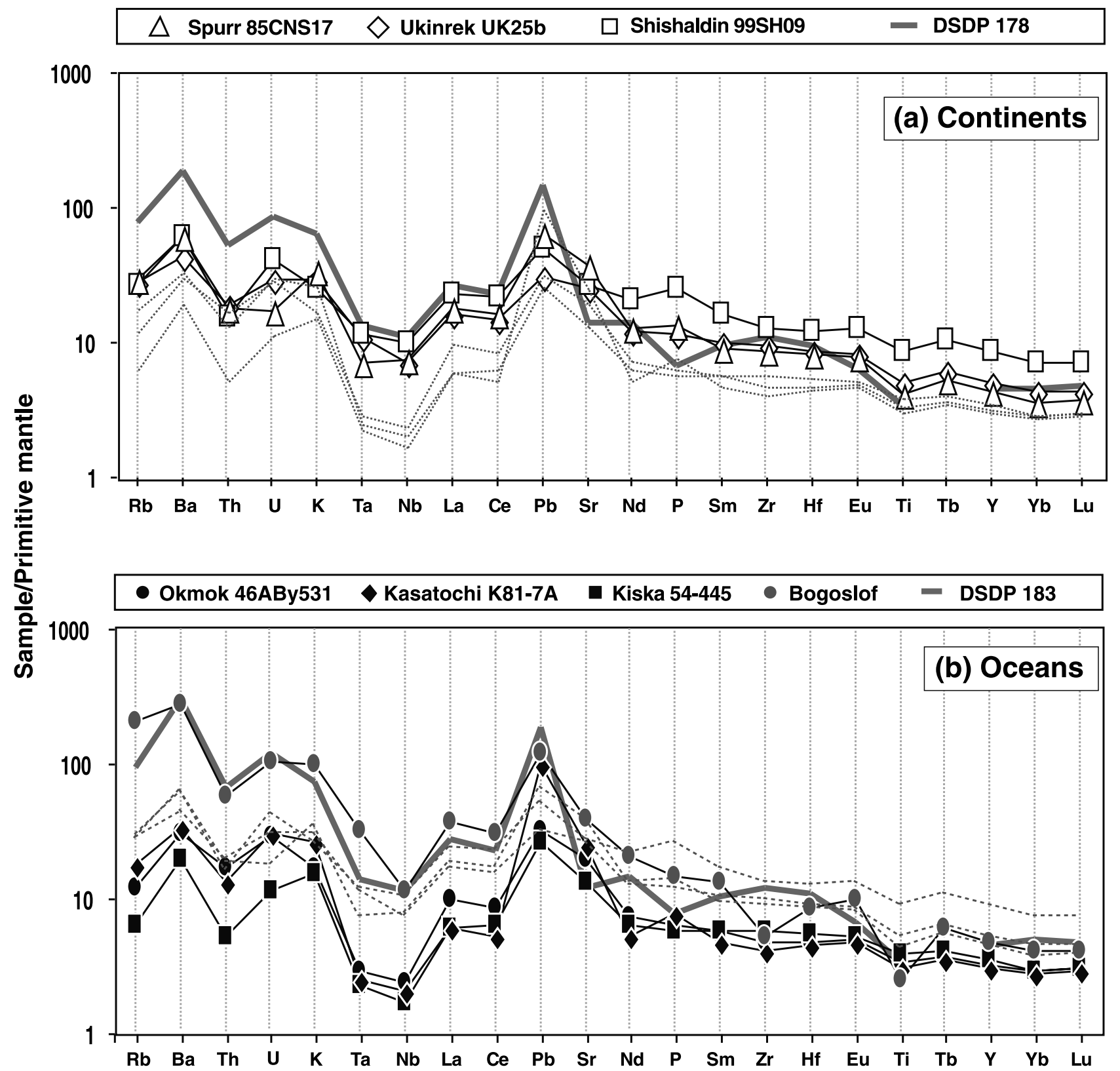

Figure 4. (a) Trace element profiles for the most primitive Alaskan lavas superimposed onto Aleutian lavas from Figure 4b (gray lines). Averaged sediment trace element concentrations from DSDP 178 [Plank and Langmuir, 1998] are shown as a thick gray line. (b) Trace element profiles for Aleutian lavas compared with Alaskan samples from Figure 4a (gray lines). DSDP 183 trace element profile [Plank and Langmuir, 1998] is shown as a gray line.

${ }^{226} \mathrm{Ra}$ typical of arc lavas; therefore accumulation of young plagioclase is also unable to account for the observed ${ }^{226} \mathrm{Ra}$ excesses. Rather, the ${ }^{226} \mathrm{Ra}$ excesses are inferred to be derived from the source region (see further discussion below). When the rear arc Bogoslof sample is removed, there is only weak evidence for a positive correlation of $\mathrm{Ra}$ excess with $\mathrm{Ba} / \mathrm{Th}$ ratio as seen in other arcs worldwide (Figure 6b, inset) [Turner et al., 2001b].

\subsection{The ${ }^{10} \mathrm{Be} /{ }^{9} \mathrm{Be}$ Ratios and $\mathrm{Be}, \mathrm{B}$, and $\mathrm{Li}$} Concentrations in Arc Lavas and Sediments

[24] The ${ }^{10} \mathrm{Be}$ concentrations range from below detection limits to a maximum value of $15 \times 10^{6}$ atoms $\mathrm{g}^{-1}$, and the
${ }^{10} \mathrm{Be} /{ }^{9} \mathrm{Be}$ ratios range from below detection limits $(<0.1)$ in the eastern Alaskan samples to a peak of $>14 \times 10^{-11}$ in the intraoceanic arc at Kasatochi (Table 1). The ${ }^{10} \mathrm{Be} /{ }^{9} \mathrm{Be}$ ratios correlate well with ${ }^{10} \mathrm{Be}$ concentrations $\left(r^{2}=0.8\right)$ for all samples except the rear arc lava from Bogoslof and show no systematic variation with ${ }^{9} \mathrm{Be}$ concentrations. The data lie within the range already reported for the Aleutians [Morris et al., 1990] but significantly expand the geographic coverage to show that there is a marked change in ${ }^{10} \mathrm{Be} /{ }^{9} \mathrm{Be}$ with position along the arc (see below). The ${ }^{9} \mathrm{Be}$ concentrations range from 0.36 to $1.35 \mathrm{ppm}$ and are generally higher in the Alaskan lavas than in the Aleutian lavas. The ${ }^{10} \mathrm{Be} /{ }^{9} \mathrm{Be}$ ratios show a good negative correlation with $\mathrm{Ce} / \mathrm{Ce}$ * (Figure $7 \mathrm{a}$ ). 
a
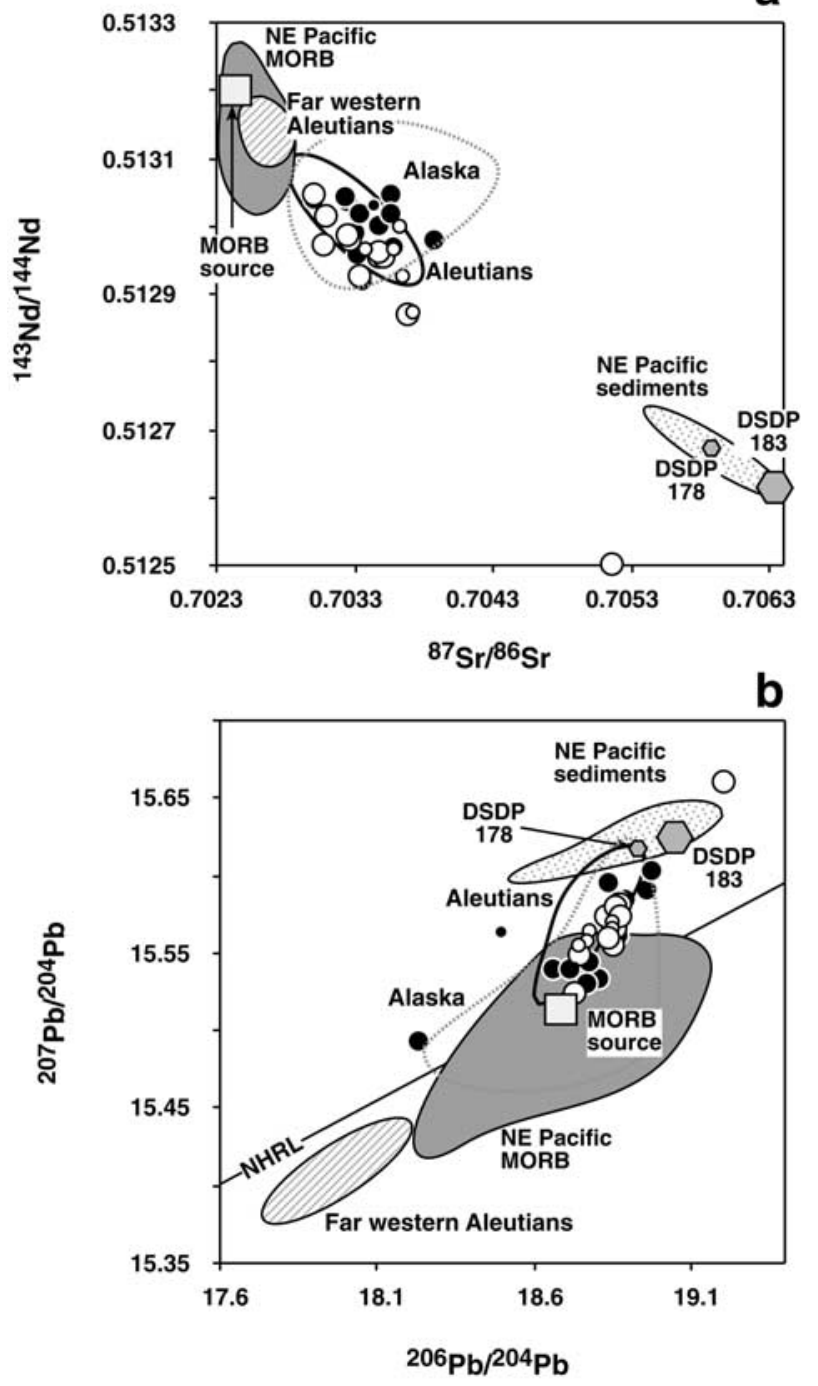

Figure 5. (a) $\mathrm{Sr}$ versus $\mathrm{Nd}$ isotope variation in the Alaskan-Aleutian suite. (b) $\mathrm{Pb}$ isotope data. Data sources and symbols as in Figure 3 and Von Drach et al. [1986] and McCulloch and Perfit [1981]. The small symbols are those with $>56 \mathrm{wt} \% \mathrm{SiO}_{2}$. The data are compared with northeastern Pacific plate sediments [Peucker-Ehrenbrink et al., 1994; Plank and Langmuir, 1998; Kelemen et al., 2003], northeastern Pacific MORB [Langmuir et al., 1992] and far western Aleutian lavas [Yogodzinski et al., 1994, 1995].

[25] $\mathrm{B}$ concentrations in the arc rocks $(1-32 \mathrm{ppm})$ are significantly higher than those observed in MORB, and fall within the range previously reported for Aleutian lavas [Ryan and Langmuir, 1993]. Li concentrations range from 6 to $23 \mathrm{ppm}$ in the Alaskan lavas, but show a more restricted range in Aleutian lavas $(7-14 \mathrm{ppm})$. B/Be ratios in our lavas range from 1.5 to 55 , and form a broadly positive correlation with ${ }^{10} \mathrm{Be} /{ }^{9} \mathrm{Be}$, as previously observed by Morris et al. [1990]. Samples from behind the volcanic front (Bogoslof) have anomalously low B/Be due to subduction-related B losses [e.g., Ryan and Langmuir, 1993], even though they have high ${ }^{10} \mathrm{Be} /{ }^{9} \mathrm{Be}$ (Table 1). More evolved lavas have anomalously low ${ }^{10} \mathrm{Be} /{ }^{9} \mathrm{Be}$, and varia- ble $\mathrm{B} / \mathrm{Be}$, consistent with the assimilation of subarc crustal materials. Be/ $\mathrm{Nd}$ ratios average 0.05 , and form a scattered positive array on a plot of Be versus $\mathrm{Nd}$ ppm, typical of tholeiitic arc basalts [Ryan, 2002]. Li systematics are also typical in that $\mathrm{Li} / \mathrm{Yb}$ ratios range from 2 to12.5 and (as with all arcs) form a vertical trend on a plot of $\mathrm{Li} / \mathrm{Yb}$ versus $\mathrm{Dy} / \mathrm{Yb}$ (not shown), indicating an absence of residual garnet in the arc source, and enrichments in $\mathrm{Li}$ relative to MORB.

[26] Interestingly, Th and $\mathrm{Ra}$ isotope systematics appear to vary independently of the light elements. Plots of $\left({ }^{226} \mathrm{Ra} /{ }^{230} \mathrm{Th}\right)$ and $\left({ }^{230} \mathrm{Th} /{ }^{232} \mathrm{Th}\right)$ versus $\mathrm{B} / \mathrm{Be}$ show horizontal arrays, with little isotopic variation over a range of $\mathrm{B} / \mathrm{Be}$. These patterns may indicate a decoupling of fluid-mobile elements such as B from $U$ (and potentially $\mathrm{Ra}$ ) due to different slab extraction history. B may mobilize earlier than $\mathrm{U}$ and may also not be mobilized beneath arcs by the same solid/fluid exchange event. Decoupling of B from other LILEs has been observed in arcs and subduction-related rocks globally [e.g., Ryan et al., 1995].

[27] Table 2 presents ${ }^{10} \mathrm{Be},{ }^{9} \mathrm{Be}$ and $\mathrm{B}$ concentration data for the incoming sediments at DSDP Site 183, and also for Site 186 inboard of the trench (see Figure 1). These sediments are diatomaceous silty clays and diatom oozes with volcanic ash interbeds. They have ${ }^{10} \mathrm{Be}$ concentrations that are highly variable and often lower than are typical of those being subducted beneath the Mariana or Central America arcs [Morris et al., 2002]. Near-surface sediments with particularly low ${ }^{10} \mathrm{Be}$ typically contain $>50 \%$ volcanic detritus [Creager et al., 1973], found in rapidly deposited ash layers or hemipelagic sediments and turbidites that have settled quickly through the water column. An exponential curve may be fitted to the data for Site 183, with a correlation of 0.83 . The total amount of ${ }^{10} \mathrm{Be}$ in the incoming sediment column (calculated by integrating under the ${ }^{10} \mathrm{Be}$ depth curve (Figure $7 \mathrm{~b}$ ), and expressed as the number of atoms per square centimeter from sediment-seawater interface to the base of the column) is $9.7 \times 10^{12}$ atoms $\mathrm{cm}^{-2}$. This amount of ${ }^{10} \mathrm{Be}$ is less than that being subducted beneath Japan or Central America, and greater than that entering the Mariana trench [Morris et al., 2002]. Because of the high sedimentation rates over the last $10 \mathrm{Myr},{ }^{10} \mathrm{Be}$ is present in the sediment column to about 200 meters below the seafloor. Be concentrations of about $0.8-1.3 \mathrm{ppm}, \mathrm{B}$ concentrations of $50-100 \mathrm{ppm}$, and $\mathrm{B} / \mathrm{Be}$ ratios of $50-100$ are typical of oceanic sediments with moderate to large terrigenous input. In comparison, DSDP Site 186 sediments are from inboard of the trench and yet they have Be isotope systematics broadly similar to those of the incoming plate, highlighting the large volcaniclastic contribution to both localities (Figure 7b). Extremely high recent sediment rates of $145-175 \mathrm{~m} / \mathrm{Myr}$ over the last $6 \mathrm{Myr}$ [Koizumi, 1973] mean that ${ }^{10} \mathrm{Be}$ is present throughout the sediment column at Site 186 . The ${ }^{10} \mathrm{Be}$ depth profiles show no pattern characteristic of imbricate thrust packets as seen in the Japan forearc [Morris et al., 2002].

\subsection{Along-Arc Variations}

[28] One of the aims of this study was to examine along-arc variations in selected chemical and isotopic signals and in particular across the oceanic-continental arc transition. Systematic along-arc variations are rare worldwide (see Lesser 

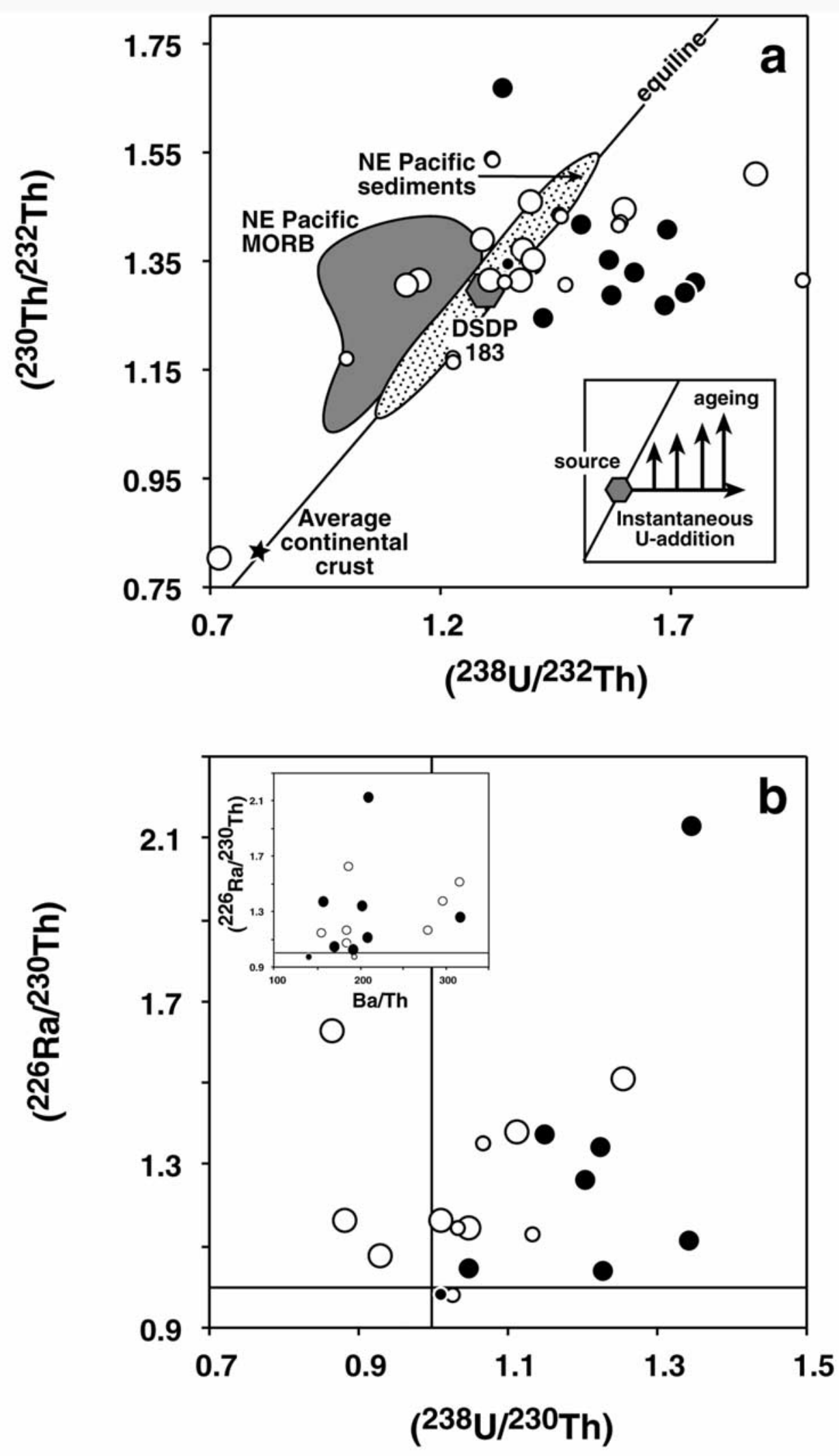

Figure 6. (a) U-Th equiline diagram showing oceanic and continental Aleutian lavas compared with northeastern Pacific MORB, sediment components (data sources as for Figure 5). Inset shows schematic effects of instantaneous $U$ addition to a sediment-dominated source region. (b) $\left({ }^{226} \mathrm{Ra} /{ }^{230} \mathrm{Th}\right)$ versus $\left({ }^{238} \mathrm{U} /{ }^{230} \mathrm{Th}\right)$ disequilibria. Inset shows Ra isotopes versus $\mathrm{Ba} / \mathrm{Th}$ ratio. The Bogoslof sample has been omitted because of its extreme Ra excess. Symbols are as in Figure 5. 

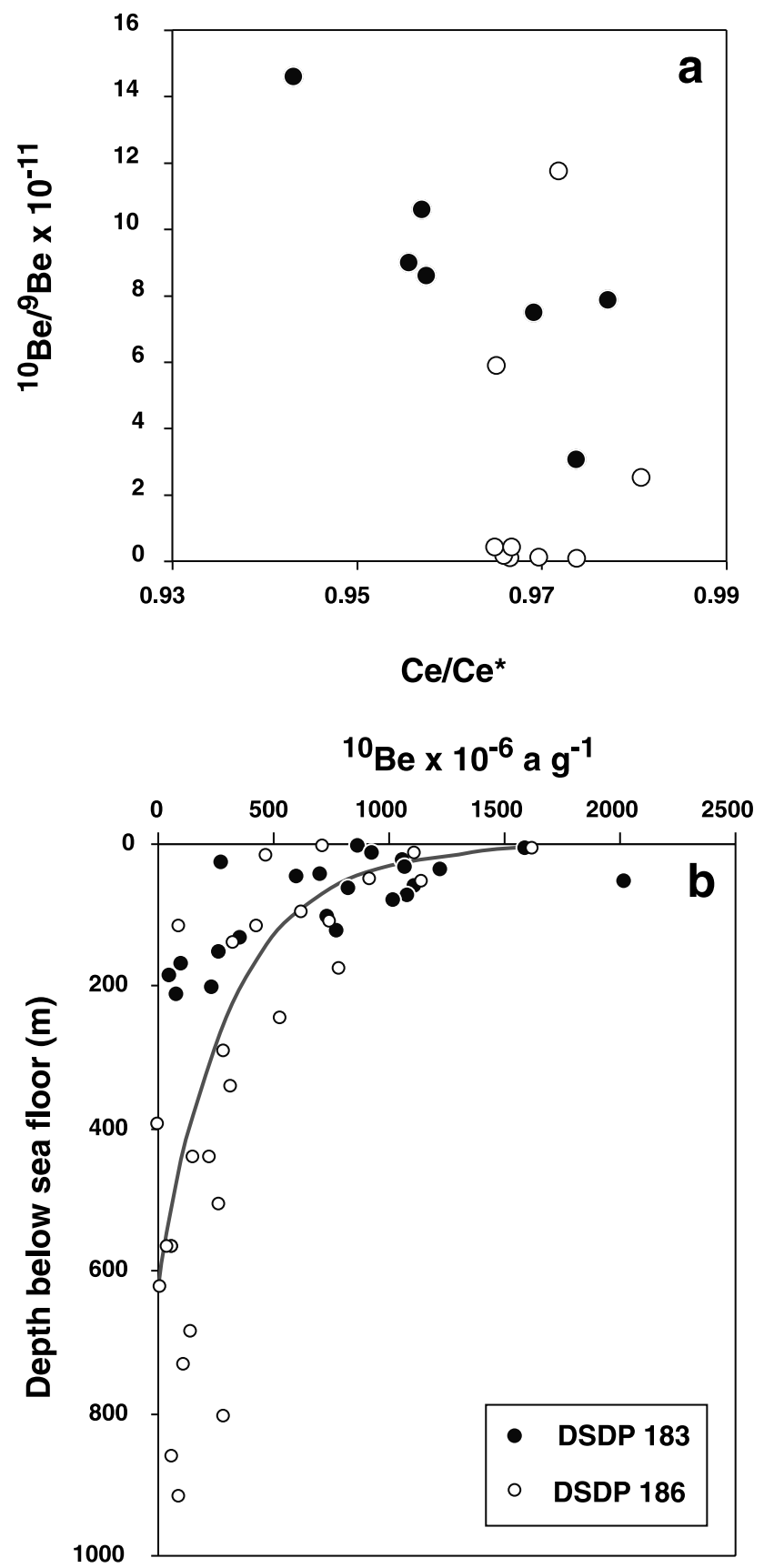

Figure 7. (a) $\mathrm{Ce} / \mathrm{Ce}^{*}$ versus ${ }^{10} \mathrm{Be} /{ }^{9} \mathrm{Be}$ ratio showing the good negative correlation observed for the Alaska-Aleutian lavas. $\mathrm{Ce} / \mathrm{Ce} *$ is defined as $\mathrm{Ce}_{\mathrm{Sa}} /\left(\mathrm{La}_{\mathrm{Sa}} / \mathrm{La}_{\mathrm{ch}}\right)+\left(\mathrm{Pr}_{\mathrm{Sa}} / \mathrm{Pr}_{\mathrm{ch}}\right) /$ $2 * \mathrm{Ce}_{\mathrm{ch}}$ (where $\mathrm{Sa}$ is sample and ch is $\mathrm{C} 1$ chondrite from Sun and McDonough [1981]. (b) The variation of ${ }^{10} \mathrm{Be}$ with depth below seafloor in Aleutian sediments from DSDP Site 183 on the incoming plate (solid circles) and 186 (open circles) inboard of the trench (data from Table 2). Best fit exponential curve (solid gray line) has been fitted to the data for Site 183; the total amount of ${ }^{10} \mathrm{Be}$ in the sediment column supplied to the subduction trench is calculated by integrating under the curve. The results and the lithologies for Site 183 are summarized in Table 3. Drilling at Site 186 penetrated $926 \mathrm{~m}$ of diatomaceous silty clay and diatom oozes with frequent volcanic ash and sand layers and occasional thin carbonate-rich horizons. All sediments are described as unit A, correlative to unit A at Site 183 [Creager et al., 1973].
Antilles [Turner et al., 1996, and references therein]), but those for $\left({ }^{238} \mathrm{U} /{ }^{230} \mathrm{Th}\right), \mathrm{Ce} / \mathrm{Ce} *,{ }^{10} \mathrm{Be} /{ }^{9} \mathrm{Be}$, and $\mathrm{Th} / \mathrm{Nb}$ in the Aleutians-Alaska arc are shown in Figure 8. The average $\left({ }^{238} \mathrm{U} /{ }^{230} \mathrm{Th}\right)$ increases from 0.88 at the eastern end of the Alaskan arc to a peak of 1.34 at Kasatochi $\left(174^{\circ} \mathrm{W}\right)$, and may begin to decrease again in the rocks farther west (Figure 8a). The rate of orthogonal convergence broadly correlates with $\left({ }^{238} \mathrm{U} /{ }^{230} \mathrm{Th}\right)$ with the highest values occurring where orthogonal convergence is greatest in the center of the arc (Figure $8 \mathrm{a}$ ). In detail, within the general trend there are variations in $\left({ }^{238} \mathrm{U} /{ }^{230} \mathrm{Th}\right)$ which we attribute (below) to the competing effects of fluid addition and partial melting. The $\mathrm{Ce}$ anomalies show less clear variations along the arc (Figure $8 b$ ), but in the oceanic rocks the lowest values occur at the site of maximum convergence rate. With one exception, the continental rocks all appear to have similar $\mathrm{Ce} / \mathrm{Ce}$ * around $0.96-0.97$. The Be isotope data show striking along-arc systematics, particularly when they are compared with calculated sediment transit times (the length of time taken for material to be transported from the trench to beneath the different island arc volcanoes) in Figure 8c. At the western end of the arc, a lava from Kiska has a small but real ${ }^{10} \mathrm{Be}$ enrichment, despite an estimated $6 \mathrm{Myr}$ transit time associated with oblique subduction. The greatest ${ }^{10} \mathrm{Be}$ enrichments occur farther east in the central Aleutians where subduction times are fastest, but note that ${ }^{10} \mathrm{Be} /{ }^{9} \mathrm{Be}$ shows considerable variation over a segment of the arc that has a relatively constant, $3 \mathrm{Myr}$ subduction time $\left(165^{\circ}-178^{\circ} \mathrm{W}\right)$. Lavas sampled from east of Shishaldin volcano $\left(<163^{\circ} \mathrm{W}\right)$ have ${ }^{10} \mathrm{Be}$ concentrations near or below detection limits, with the exception of one anomalously high ${ }^{10} \mathrm{Be}$ measurement in an Aniakchak lava (not plotted). In detail, Trident, Ukinrek, and two of the Aniakchak lavas have near negligible ${ }^{10} \mathrm{Be}$, although the transit times are short enough to have retained some ${ }^{10} \mathrm{Be}\left(5.3-6.3 \mathrm{Myr}:{ }^{10} \mathrm{Be}\right.$ will have decayed in $9 \mathrm{Myr}$, or 6 times the half-life). By comparison, for Spurr and Redoubt volcanoes, the wide arc-trench gap makes for very long subduction times allowing complete ${ }^{10} \mathrm{Be}$ decay in the sediments during transport to the depths of magma generation. Finally, Figure $8 \mathrm{~d}$ highlights that $\mathrm{Th} / \mathrm{Nb}$ ratios reach their peak where Be isotope ratios are greatest, and the lavas from the center of the oceanic sector have significantly higher $\mathrm{Th} / \mathrm{Nb}$ ratios $(>0.7)$ than those either further east or west $(\mathrm{Th} / \mathrm{Nb}<0.7)$. It is argued below that these high $\mathrm{Th} / \mathrm{Nb}$ ratios reflect partial melting of the subducted sediment.

\section{Discussion and Interpretation}

[29] This section first considers the effects of crustal contamination, with emphasis on Th isotopes, which may be a more sensitive indicator of crustal contamination in geologically young terrains than longer half-life isotope systems. Having identified samples which appear not to have been contaminated significantly with crustal material, we consider the evidence for partial melts from the subducted slab, the timescales of sediment transport, and melt generation models and whether these change with tectonic and thermal regimes along the arc.

\subsection{Crustal Contamination}

[30] The rocks analyzed were selected because they were young enough for $U$ series isotope studies, and they are not 

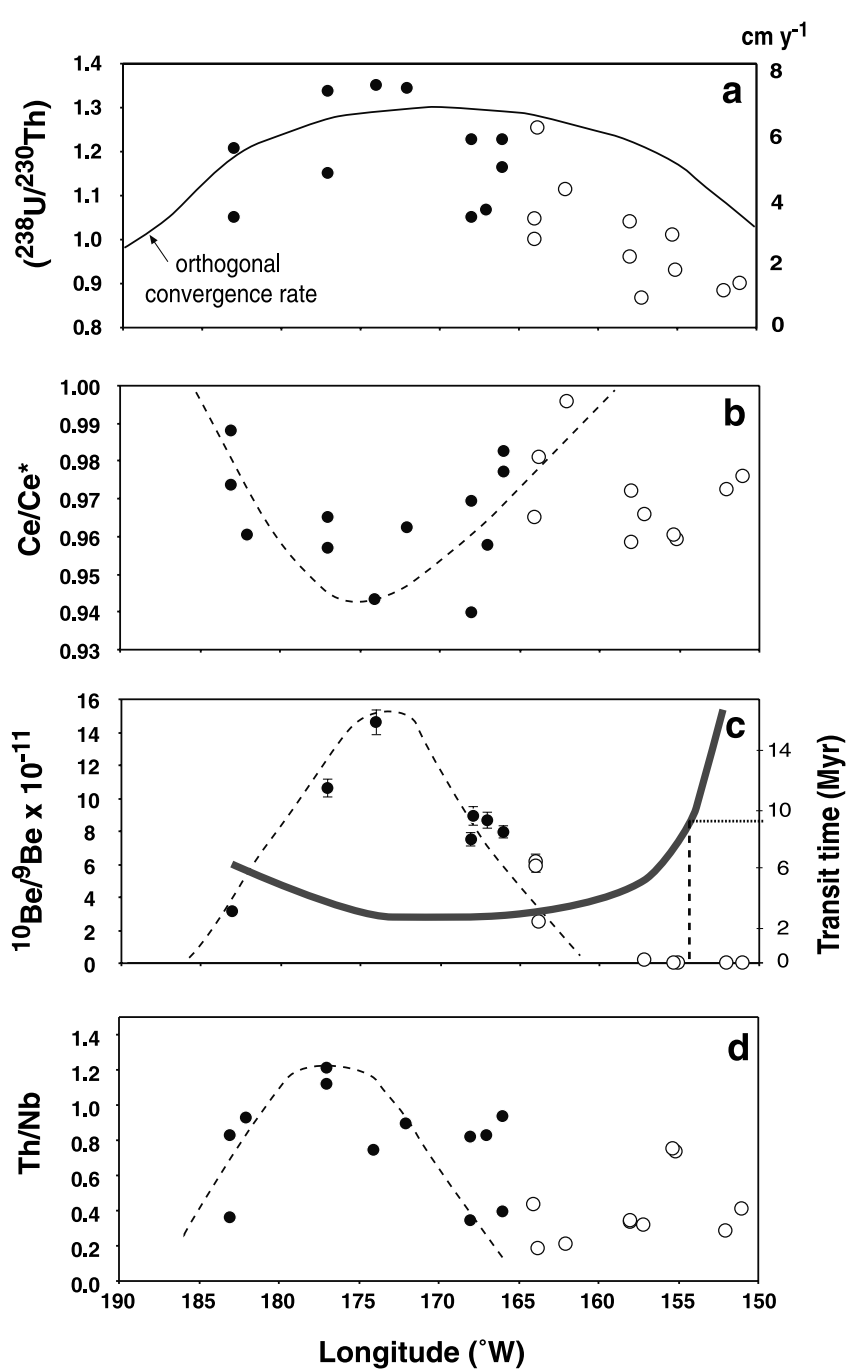

Figure 8. Along-arc variations of (a) $\left({ }^{238} \mathrm{U} /{ }^{230} \mathrm{Th}\right)$, (b) $\mathrm{Ce} / \mathrm{Ce}^{*}$, (c) ${ }^{10} \mathrm{Be} /{ }^{9} \mathrm{Be}$ ratios, and (d) $\mathrm{Th} / \mathrm{Nb}$. Orthogonal convergence rate in Figure $8 \mathrm{a}$ is taken from Figure 2a. Dashed curves in Figures $8 b-8 d$ illustrate the preferred interpretation of the data in light of the calculated sediment flux in Figure 2c. In Figure 8c, samples to the right of the vertical dashed line have transit times (calculated from orthogonal convergence rate, slab dip, and orthogonal trench-volcano distance) that are sufficiently long that all subducted ${ }^{10} \mathrm{Be}$ has decayed.

necessarily cogenetic. Since they were sampled over $2500 \mathrm{~km}$ along the arc, it would be unlikely to find tight correlations between isotope ratios and indices of differentiation and/or crustal contamination. Further, in the igneous basement rocks of Alaska and the Aleutians, $\mathrm{Sr}$ isotope ratios are low (0.7024 on average) [Arth, 1994], and so in some areas, there may be no marked $\mathrm{Sr}$ and $\mathrm{Nd}$ isotope differences between likely contaminants and the arc lavas. Exceptions include the Buzzard Creek lava and to a lesser extent the more evolved samples from Spurr and Redoubt. These also have lower Th isotope ratios than the rest of the suite (Figure 6). In general, the more a melt has crystallized, the more chance there is that it has assimilated wall rock. Thus we have omitted rocks with $>56 \mathrm{wt} \% \mathrm{SiO}_{2}$ from the following discussion to minimize the likely effects of crustal contamination (they are subsequently plotted as small circles).

[31] Although there may have been insufficient time to have developed differences in the $\mathrm{Sr}, \mathrm{Nd}$, and $\mathrm{Pb}$ isotope ratios of the crustal rocks and new mantle-derived magmas, differences in Th isotopes may be generated in a few tens of thousands of years. The effects of crustal contamination can therefore be inferred from Th isotopes as illustrated on a plot of $\left({ }^{230} \mathrm{Th} /{ }^{232} \mathrm{Th}\right)$ versus ${ }^{143} \mathrm{Nd} /{ }^{144} \mathrm{Nd}$ (Figure 9). Here we compare the data for the Alaska-Aleutian rocks with those for the DSDP sediments and average continental crust. The Th isotope ratios were calculated from the measured U/Th ratios, assuming short-lived isotope equilibrium. The crustal compositions have very low U/Th ratios, and hence low Th isotope values, and these will be developed on a much shorter timescale $(350 \mathrm{kyr})$ than that required for $\mathrm{Nd}$ isotopes to reflect the low $\mathrm{Sm} / \mathrm{Nd}$ ratios of continental crust. The estimated low $\mathrm{Th}$ and $\mathrm{Nd}$ isotope ratios of the continental crust offer a satisfactory end-member for the Buzzard Creek

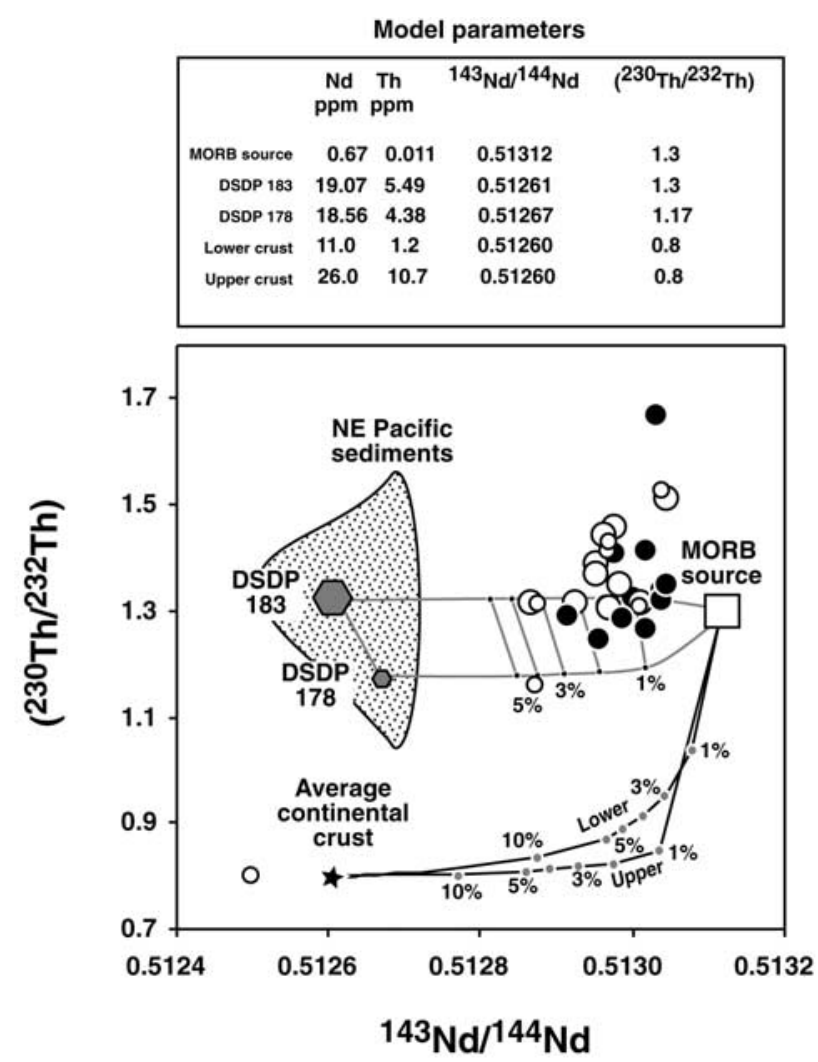

Figure 9. Th isotope-Nd isotope diagram comparing Aleutian lavas with mixing trajectories between N-MORB source mantle wedge [Stolper and Newman, 1994], Aleutian sediment [Plank and Langmuir, 1998] and continental crustal compositions using elemental concentrations from Rudnick and Fountain [1995]. Isotope ratios for continental components were assumed to be close to that of the down-going sediments as they are essentially sourced from mainland Alaskan continental crust. Lithological components in DSDP 178 and 183 holes are shown (stippled field). Samples with greater than $56 \mathrm{wt} \% \mathrm{SiO}_{2}$ are plotted as small symbols. 
sample $\left(\left({ }^{230} \mathrm{Th} /{ }^{232} \mathrm{Th}\right)=0.8\right)$ and an explanation for the relatively low $\left({ }^{230} \mathrm{Th} /{ }^{232} \mathrm{Th}\right)$ in the Spurr and Redoubt rocks (1.16-1.31) compared with other Alaskan samples. Note that the Th activity ratios of MORB older than 350 ka would also be $<1.3$.

[32] The oceanic samples show restricted ranges in $\mathrm{Nd}$ and Th isotopes and lie close to the mantle-sediment mixing array (Figure 9). Sediment largely dictates the $\left({ }^{230} \mathrm{Th} /{ }^{232} \mathrm{Th}\right)$ of the mantle source for these samples [e.g., Turner et al., 1996; Elliott et al., 1997], and few intraoceanic samples have $\mathrm{Th}$ isotope ratios lower than this. The continental samples on the other hand, show the same range in $\mathrm{Nd}$ isotopes but trend toward higher Th isotope ratios. This is not controlled by contamination with average crust nor by subducted sediment as represented by samples from the nearest DSDP hole (178) which have lower rather than higher inferred Th isotope ratios of $\sim 1.2$ (Figure 9). As discussed in more detail below, it might be due to (1) longer periods of time between the introduction of high U/Th fluids from the slab and eruption and/or (2) shifts to higher $\left({ }^{230} \mathrm{Th} /{ }^{232} \mathrm{Th}\right)$ ratios during partial melting. Thus, apart from the Buzzard Creek, Redoubt and Spurr samples, the rocks analyzed do not have the low Th isotope ratios inferred for even young continental crust, nor are they displaced toward such material. We therefore argue that the U-Th systematics, and by implication the other isotope and trace element characteristics, of most of the low $\mathrm{SiO}_{2}$ samples have not been significantly perturbed by crustal contamination, and they are interpreted to reflect processes intrinsic to their mantle source regions.

\subsection{Partial Melts From the Subducting Plate}

[33] A number of studies have argued that some island arc magmas contain contributions from melts of basalt [Defant and Kepezhinskas, 2001; Yogodzinski et al., 2001; Kelemen et al., 2003] and/or melts of sediment [Elliott et al., 1997; Turner et al., 1997; Hoogewerff et al., 1997; Johnson and Plank, 1999; Class et al., 2000] derived from the subducted oceanic plate. We now consider these possibilities separately.

\subsubsection{Partial Melts of Basalts in the Subducted Crust}

[34] Basaltic rocks in the down-going crust convert to eclogite at depths of $>65 \mathrm{~km}$ [Evans, 1990; Peacock, 1996]. Existing thermal models suggest that this part of the slab melts only if young, hot crust is subducted [Peacock et al., 1994]. However, these thermal models appear to conflict with geochemical evidence that subducted sediments undergo partial melting beneath many arcs [Elliott et al., 1997; Turner et al., 1997; Johnson and Plank, 1999; Class et al., 2000]. Recognition of slab-derived melts of basaltic crust typically relies on evidence for the presence of residual garnet and in some cases rutile, although residual rutile may also be present during partial melting of sediment [Turner et al., 1997; Elliott et al., 1997; Class et al., 2000]. Yogodzinski and Kelemen [1998] and Kelemen et al. [2003] regarded high $\mathrm{Sr} / \mathrm{Y}, \mathrm{Dy} / \mathrm{Yb}$ and $\mathrm{La} / \mathrm{Yb}$ ratios in the far western Aleutians as particularly characteristic of partial melts from the slab, and concluded that these slab melts also had high $\mathrm{Th} / \mathrm{Nb}$ because of the presence of residual rutile. They further suggested that such components might be present along the length of the oceanic Aleutian arc. However, the young samples analyzed in our study are all from volcanoes east of the far western Aleutians and none have those distinctive high $\mathrm{Sr} / \mathrm{Y}, \mathrm{Dy} / \mathrm{Yb}$, and $\mathrm{La} / \mathrm{Yb}$ ratios (Figures $10 \mathrm{a}$ and $10 \mathrm{~b}$ ). Rather, their $\mathrm{Sr} / \mathrm{Y}$ ratios are in the range for "normal" arc lavas (<50 [Gill, 1981]), and they have low and restricted $\mathrm{La} / \mathrm{Yb}, \mathrm{Li} / \mathrm{Yb}$, and $\mathrm{Tb} / \mathrm{Yb}$ ratios. Assuming a sediment-modified MORB mantle source, the range of $\mathrm{La} / \mathrm{Yb}$ ratios in the lavas of this study are consistent with an average degree of melting of $12 \%$ (Figure 10a). Using these parameters, the $\mathrm{Tb} / \mathrm{Yb}$ ratios in Figure $10 \mathrm{~b}$ have been calibrated for percent residual garnet (Figure 10b). As can be seen none of the lavas of this study require residual garnet on the basis of $\mathrm{Tb} / \mathrm{Yb}$ ratios, suggesting that residual garnet was not present during melting (Figures 10a and 10b).

[35] In order to assess whether slab melting was an important process in the past in the Aleutians, we have also plotted the available data from older lavas on Figure 10. It can be seen that on several islands, the older lavas extend to higher $\mathrm{La} / \mathrm{Yb}$ and $\mathrm{Tb} / \mathrm{Yb}$ than any of the young samples analyzed in this study. If the same source composition is relevant, these higher ratios may indicate a role for residual garnet during magma genesis in the past but there is no evidence that it was ubiquitous.

[36] Partial melts of the subducted Pacific basaltic crust are likely to be indistinguishable from Pacific mantle wedge in relatively immobile radiogenic isotope ratios such as ${ }^{143} \mathrm{Nd} /{ }^{144} \mathrm{Nd}$. However, partial melting of basalt in eclogite facies will strongly increase $\mathrm{Th} / \mathrm{Nd}$ ratios in the melts due to the incompatibility of Th relative to REE in clinopyroxene and garnet [Blundy et al., 1998; Wood et al., 1999]. Thus, on a plot of ${ }^{143} \mathrm{Nd} /{ }^{144} \mathrm{Nd}$ versus $\mathrm{Th} / \mathrm{Nd}$, a mantle wedgeeclogite mixing vector is horizontal and, as Figure 11a shows, this cannot be primarily responsible for the Alaska-Aleutian data. The dashed mixing lines on Figure 11a show that a more complex model, involving mixing between a mantle wedge, containing $\sim 1 \%$ eclogitic melt, and bulk sediment could, in principle, explain much of the data. Such a model is difficult to test, but there is some evidence suggesting that the elevated $\mathrm{Th} / \mathrm{Nd}$ ratios primarily reflect contributions from subducted sediment. First, slab melts formed in the presence of residual garnet will have ${ }^{230} \mathrm{Th}$ excesses as observed in adakitic melts from Mount Shasta and the austral Andes [Newman et al., 1986; Sigmarsson et al., 1998]. However, in the Aleutians, ${ }^{230} \mathrm{Th}$ excesses do not increase toward the region of inferred hotter slab in the west (Figure 6) and the higher $\mathrm{Th} / \mathrm{Nd}$ rocks do not systematically have ${ }^{230} \mathrm{Th}$ excesses or higher $\mathrm{Tb} / \mathrm{Yb}$ (Figure 10b). Second, there is a generally positive correlation between $\mathrm{Th} / \mathrm{Nd}$ and ${ }^{10} \mathrm{Be} /{ }^{9} \mathrm{Be}$ ratios which confirms that the elevated $\mathrm{Th} / \mathrm{Nd}$ ratios occur in those rocks containing larger sediment contributions (Figure 11b). In summary, the isotope and trace element evidence for partial melts of basaltic subducted crust is best seen in lavas from the far west of the Aleutians where slab surface temperatures are anomalously hot due to plate tearing (Figure 10) [Yogodzinski et al., 2001]. Contributions from such a component are much harder to identify in the young rocks of this study to the east, but if present they are likely to be no more than 1\% (Figure 11a). Such small contributions will not significantly raise the silica content of unfractionated (high Mg number) magmas entering the lithosphere and so are unlikely to be the key to the formation of average continental crust. 

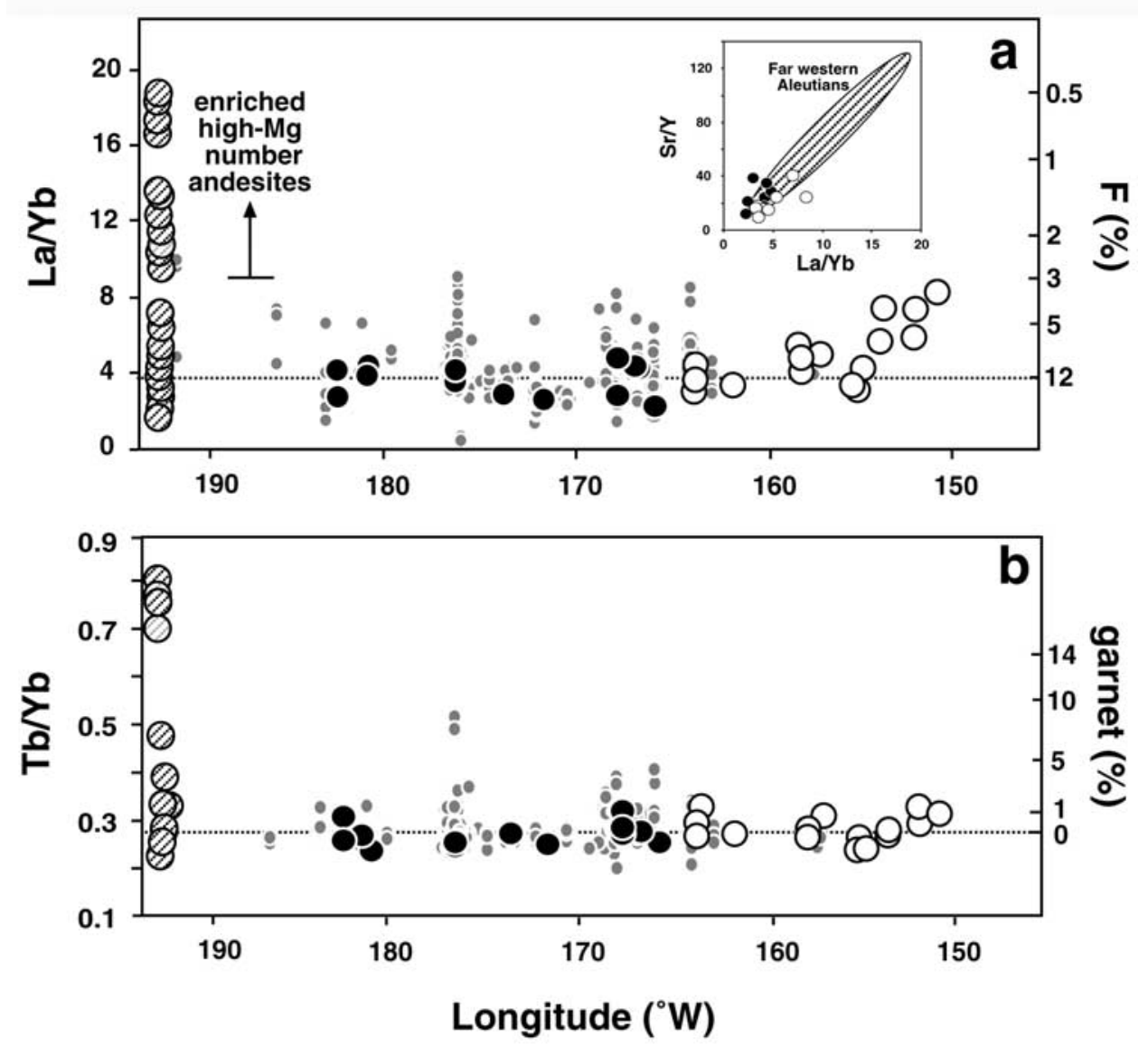

Figure 10. (a) Along-arc $\mathrm{La} / \mathrm{Yb}$ variations with an inset of $\mathrm{Sr} / \mathrm{Y}-\mathrm{La} / \mathrm{Yb}$ ratios in Aleutian lavas contrasted with the far western volcanics. Nonhistoric lavas with $<56 \mathrm{wt} \% \mathrm{SiO}_{2}$ from the J. Myers and $\mathrm{T}$. McElfrish (unpublished data compilation) are plotted as gray symbols. Data sources as in Figure 5. Righthand axis shows melt fraction calculated from nonmodal batch melting of a MORB source mantle plus $1 \%$ Aleutian sediment melt with a source mineralogy of $43 \%$ olivine, $42 \%$ orthopyroxene, and $15 \%$ clinopyroxene using partition coefficients from Blundy et al. [1998] and Halliday et al. [1995]. Dotted line shows average melt fraction indicated by the data of this study. (b) $\mathrm{Tb} / \mathrm{Yb}$ variations along the Alaska-Aleutians comparing the data presented in this study along with data from Piip and the Komandorsky islands [Yogodzinski et al., 1994, 1995] and older lavas. Maximum permissable proportion of garnet in the mantle source is shown on right-hand axis and was calculated using the same model as Figure 10a assuming 12\% partial melting as determined from Figure 10a (this model is relatively insensitive to the amount of sediment added to the source). High $\mathrm{Tb} / \mathrm{Yb}$ ratios, that would allow for derivation from a source bearing residual garnet, are observed only in the far west and in some of the older lavas on a couple of islands.

\subsubsection{Subducted Sediment Input}

[37] Kelemen et al. [2003] appeal to an absence of systematic along-arc variations in sediment indicators and between sediment indicators and radiogenic isotopes in their data set as one of their motivations for exploring the possibility of contributions from partial melts of the basaltic subducted crust. However, our data provides compelling evidence, from $\mathrm{Be}$ isotopes, the $\mathrm{Ce}$ anomalies, and the $\mathrm{Th}-$ $\mathrm{Nd}$ isotope variations (Figure 9), that at least the young Aleutian-Alaskan lavas contain significant contributions from subducted sediment and that these do vary systematically along arc (Figures $8 \mathrm{~b}$ and $8 \mathrm{c}$ ). Such contributions may in principle be transferred as bulk sediment scraped off the down-going slab, as partial melts, or in fluids released during dehydration. Our approach is to evaluate whether the sediment end-member has trace element ratios within the range of those in the bulk sediments, or whether they are fractionated and in that case whether those fractionations are due to partial melting or fluid release [e.g., Elliott et al., 1997; Hawkesworth et al., 1997; Turner et al., 1997; Class et al., 2000].

[38] Sediment addition as a partial melt has been inferred from departures of $\mathrm{Th} / \mathrm{Nb}$ and $\mathrm{Th} / \mathrm{Nd}$ ratios from bulk sediment-mantle mixing lines for Aleutian lavas from Umnak Island [Class et al., 2000]. Our data show a similar feature (Figure 11a) where many of the rocks have higher $\mathrm{Th} / \mathrm{Nd}$ ratios than that predicted by simple mixing between MORB source mantle and bulk sediment. The amounts of sediment involved $(<3 \%)$ are similar to those inferred from Figure 9 , but the higher $\mathrm{Th} / \mathrm{Nd}$ ratios in the volcanics are 


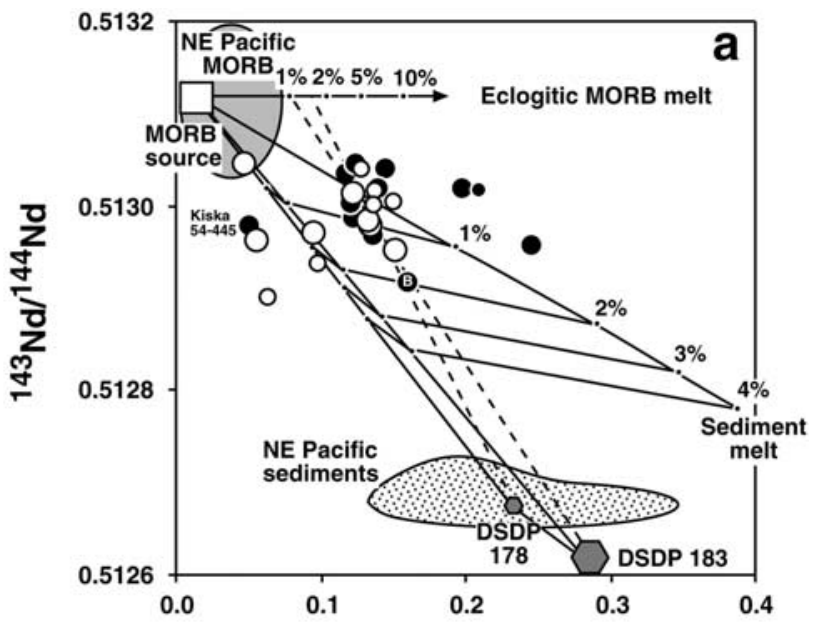

$\mathrm{Th} / \mathrm{Nd}$

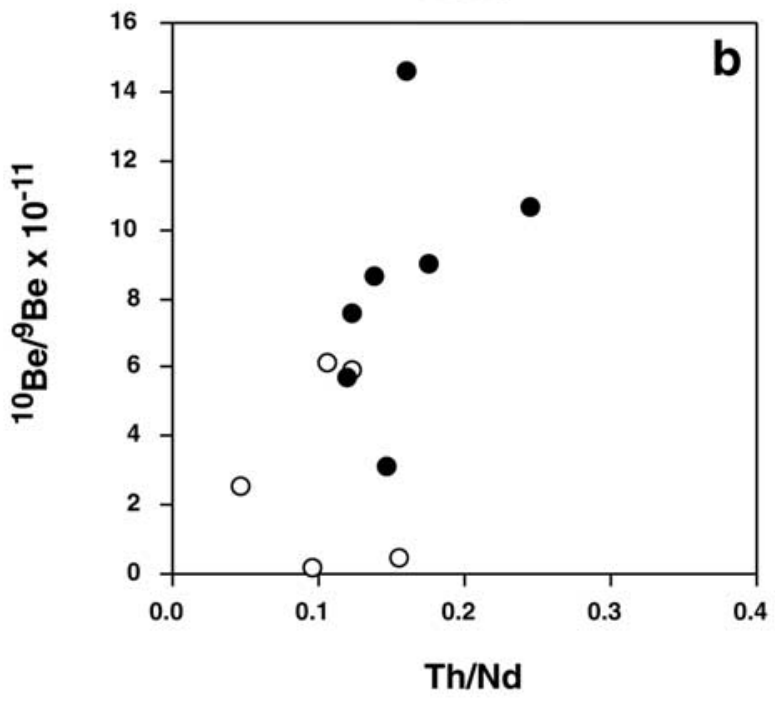

Figure 11. (a) Plot of $\mathrm{Th} / \mathrm{Nd}$ versus ${ }^{143} \mathrm{Nd} /{ }^{144} \mathrm{Nd}$ of Aleutian-Alaskan lavas compared with mixing trajectories for bulk sediment-modified mantle and mantle modified by mixing with a sediment partial melt constructed by batch melting DSDP 183 with a $20 \%$ biotite, $70 \%$ plagioclase, $10 \%$ rutile residual mineralogy. End-member compositions are given in Figure 9. The melt fraction was assumed to be small (2\%), and $\mathrm{Nd}$ was made more compatible in rutile than Th. Sample 54-445 (Kiska) has the lowest $\mathrm{Th} / \mathrm{Nd}$ ratio of the Aleutian suite but is still within the potential range of mantle-sediment mixes if the range of $\mathrm{Th} / \mathrm{Nd}$ ratios exhibited in N Pacific sediments is considered. Also shown is a trajectory for mantle modified by the addition of eclogitic partial melts of the basaltic subducted crust. The eclogitic melt was modeled as a $2 \%$ batch partial melt of MORB $(\mathrm{Th}=0.109 \mathrm{ppm}, \mathrm{Nd}=5.02 \mathrm{ppm})$ formed in the presence of equal amounts of residual garnet $\left(\mathrm{D}_{\mathrm{Th}}=0.0015\right.$, $\left.\mathrm{D}_{\mathrm{Nd}}=0.027\right)$ and aluminous clinopyroxene $\left(\mathrm{D}_{\mathrm{Th}}=0.027\right.$, $\mathrm{D}_{\mathrm{Nd}}=0.19$ ). The dashed lines illustrate possible mixing lines between eclogite melt-modified mantle wedge and bulk sediment. (b) A plot of ${ }^{10} \mathrm{Be} /{ }^{9} \mathrm{Be}$ versus $\mathrm{Th} / \mathrm{Nd}$ showing that those rocks with the highest $\mathrm{Th} / \mathrm{Nd}$ ratios also have the highest ${ }^{10} \mathrm{Be} /{ }^{9} \mathrm{Be}$, suggesting that it was the addition of sediment melts, rather than partial melts of the basaltic subducted crust, that was responsible for the elevated $\mathrm{Th} / \mathrm{Nd}$ ratios. most simply attributed to fractionation during partial melting of the sediment. Th is less mobile in fluids than $\mathrm{Nd}$ [Brenan et al., 1995], and so the fractionation to higher $\mathrm{Th} / \mathrm{Nd}$ ratios cannot reasonably be due to mobilization of the sediment component in hydrous fluids. Figure 11a therefore presents a mixing line between a MORB mantle source and a small degree (2\%) partial melt of DSDP 183 bulk sediment, showing that this could be a plausible mechanism for the fractionation of $\mathrm{Th}$ from $\mathrm{Nd}$. Not all of our data require $\mathrm{Th}$ and $\mathrm{Nd}$ to have fractionated from each other during sediment partial melting. Samples from Kiska, Shishaldin, Pavlof, Ukinrek, and Spurr can be explained by variable mixing of bulk sediment with MORB mantle without recourse to partial melting. Thus it is largely those rocks from the central oceanic sector of the arc that appear to require addition of the sediment component as a partial melt.

[39] Negative Ce anomalies in lavas (Figure 8b) are widely regarded as a fingerprint for oceanic sediments, and yet they are not observed in the DSDP 183 and 178 sediment cores [Plank and Langmuir, 1998; Toyoda et al., 1990]. However, neither drill hole intersects all of the lithologies present along the Aleutian arc. DSDP 183 comprises trench axis turbidites underlain by the Zodiak fan turbidite sequence but this lenses out westward into diatom-rich pelagic oozes [Kelemen et al., 2003]. Pelagic lithologies are much more likely to show Ce anomalies than terrigenous ones because they contain appreciable fish debris with Ce depletions inherited from seawater [Toyoda et al., 1990]. We are confident that the Ce anomalies are not analytical artifacts because their range is beyond analytical error, and they are also observed in other high-quality ICPMS data sets for Aleutian volcanics [Weber, 1998; Class et al., 2000]. Moreover, the $\mathrm{Ce}$ anomalies also correlate positively with ${ }^{10} \mathrm{Be} /{ }^{9} \mathrm{Be}$ ratio in the Aleutian segment (Figure 7a). Ce anomalies can be generated during interaction between melt and highly oxidizing fluids [Rogers and Setterfield, 1994], but the largest fluid signals are found in samples with the smallest $\mathrm{Ce}$ anomalies (see Figures 8a and $8 b$ ). Alternatively, the Ce anomalies could be produced and/or enhanced during sediment partial melting under oxidizing conditions, or they may just indicate that the sediment being subducted in the central Aleutians is different from that sampled at the DSDP drill holes.

\subsection{Sediment Dynamics}

[40] The amount of sediment-derived ${ }^{10} \mathrm{Be}$ in arc volcanic rocks depends on the ${ }^{10} \mathrm{Be} /{ }^{9} \mathrm{Be}$ ratio of the incoming sediments, the fate of the uppermost sediments through the forearc, and the time required to subduct sediments to the depths of magma generation. Calculated estimates of the bulk sediment composition are given (Tables 2 and 3), showing the effects of varying subduction time on endmember isotopic ratios. The effects on the $\mathrm{Be}$ isotope composition of accretion of the upper $5,10,15$, and $40 \%$ of the incoming sediment column are reported in the caption. Continental Alaskan lavas east of Westdahl $\left(160-150^{\circ} \mathrm{W}\right)$ have variable ${ }^{143} \mathrm{Nd} /{ }^{144} \mathrm{Nd}$ at zero ${ }^{10} \mathrm{Be}$ (Spurr, Redoubt, Trident, Ukinrek, and Aniakchak volcanoes). Figure $2 \mathrm{~b}$ shows that Spurr and Redoubt volcanoes, east of $155^{\circ} \mathrm{W}$, are characterized by long transit times such that all ${ }^{10} \mathrm{Be}$ would decay during subduction. For Trident, 
Table 3. DSDP 183 Summary $^{\mathrm{a}}$

\begin{tabular}{|c|c|c|c|c|c|c|c|c|c|}
\hline Unit & Lithology & $\begin{array}{c}\text { Interval, } \\
\text { mbsf }\end{array}$ & $\begin{array}{c}\text { Thickness, } \\
\mathrm{m}\end{array}$ & $\begin{array}{l}\text { Density, } \\
\mathrm{g} \mathrm{cm}^{-3}\end{array}$ & $\begin{array}{l}\text { Total } \\
{ }^{10} \mathrm{Be}^{\mathrm{b}}\end{array}$ & $\begin{array}{l}\text { Average } \\
{ }^{9} \mathrm{Be}, \mathrm{ppm}\end{array}$ & $\begin{array}{c}{ }^{9} \mathrm{Be}, \\
\mu \mathrm{g}\end{array}$ & $\begin{array}{c}{ }^{10} \mathrm{Be} / /^{9} \mathrm{Be} \\
\text { Atom Ratio }\end{array}$ & $\begin{array}{c}{ }^{10} \mathrm{Be} /{ }^{9} \mathrm{Be} \\
\text { Decay Corr } \\
\end{array}$ \\
\hline A & pelagic and hemipelagic & $0-210$ & 210 & 1.55 & 9.7 & 1.13 & 14950 & 971 & 243 \\
\hline B & pelagic clay & $210-240$ & 30 & 1.7 & 0 & 1.35 & 2552 & & \\
\hline $\mathrm{C}$ & chalk & $240-250$ & 10 & 1.8 & 0 & 0.25 & 158 & & \\
\hline $\mathrm{D}$ & turbidite & $250-501$ & 251 & 1.8 & 0 & 1.07 & 17190 & & \\
\hline $\mathrm{E}$ & Fe-clay and chalk & $501-505$ & 4 & & na & na & na & & \\
\hline Total & & & 505 & & 9.7 & & 34848 & 417 & 104 \\
\hline
\end{tabular}

${ }^{\text {a Sediment }}{ }^{10} \mathrm{Be}$ measurements made at University of Pennsylvania Tandem Accelerator Laboratory, uncertainty is $10 \%$, one sigma. Sediment ${ }^{9} \mathrm{Be}$ and $\mathrm{B}$ measurements made at Department of Terrestrial Magnetism, Carnegie Institution of Washington. Uncertainties are 5-10\%, one sigma.

${ }^{\mathrm{b}}$ Total ${ }^{10} \mathrm{Be}$ is the amount of ${ }^{10} \mathrm{Be}$ in the sedimentary unit, determined by integrating under the exponential curve in Figure 7 . In units of $10^{12}$ atoms for a $1 \mathrm{~cm}$ by $1 \mathrm{~cm}$ by $210 \mathrm{~m}$ thick sediment column.

${ }^{\mathrm{c}}$ Atom ratio, $\times 10^{-11}$.

${ }^{\mathrm{d}}$ Atom ratio-corrected for ${ }^{10} \mathrm{Be}$ decay during 3 Ma subduction time.

Spurr, and Aniakchak $\left(155-160^{\circ} \mathrm{W}\right)$ transit times $(4-4.5$ Myr) are short enough that some ${ }^{10} \mathrm{Be}$ would be present in the subducting sediment column. The trend toward a subducted end-member with near-zero ${ }^{10} \mathrm{Be}$ in Figure 12 suggests that the sediment component in the eastern arc has either spent additional time aging during subduction in the mantle or more sediment has been lost by accretion. Accretion of the upper $40 \%$ of the sediment column or a total ${ }^{10} \mathrm{Be}$ transit time of $\sim 9 \mathrm{Myr}$ (subduction plus any mantle storage time) would produce a sediment component with a ${ }^{10} \mathrm{Be} /{ }^{9} \mathrm{Be}$ ratio of $<4-5 \times 10^{-11}$, consistent with the mixing trend for lavas east of Westdahl.

[41] More interesting, perhaps, are the data for volcanic front lavas to the west of $164^{\circ} \mathrm{W}$. The inset to Figure 12 shows that these data fall on or close to a single trend, with a linear correlation coefficient of 0.88 . Falling on or near this trend are lavas from volcanoes built on continental crust, Shishaldin (S), Westdahl (W), and one anomalous lava from Aniakchak (A). The Be-Nd isotope correlation is presumably a mixing trend between mantle and a relatively homogenous sediment component (with respect to Be isotopes), consistent with models in which the variation in $\mathrm{Nd}$ isotope ratios reflects the contributions from subducted sediment. Significantly, the implied ${ }^{10} \mathrm{Be} /{ }^{9} \mathrm{Be}$ ratio of the sedimentary end-member is lower than that predicted for subduction of all the $\mathrm{Be}$ in the sediment column with a transit time of 3.5 Myr (the time taken for subduction along this oceanic part of the arc from Figure 2b). The inferred low ${ }^{10} \mathrm{Be} /{ }^{9} \mathrm{Be}$ ratio in the sediment component could be achieved by removal of the upper $10-15 \%$ of the incoming sediment, or by storing the subducted sediment in the wedge for an additional $\sim 0.5-1 \mathrm{Myr}$ [cf. Turner and Hawkesworth, 1997]. Moreover, given the implied similarity of the $\mathrm{Be}$ and $\mathrm{Nd}$ isotope ratios of the sediment component along the arc west of about $164^{\circ} \mathrm{W}$, it appears that the transport time for the sediment component was also similar along this segment of the arc. Finally, it is worth noting that Bogoslof, behind the volcanic front, and Umnak, its paired volcano at the front, have similar ${ }^{10} \mathrm{Be} /{ }^{9} \mathrm{Be}$ ratios (Bogoslof is $9 \times$ $10^{-11}$; Umnak is $7.5 \times 10^{-11}$ ) despite the fact that any path to the rear arc is longer, allowing greater decay in transit. Using the geometry and convergence rates in Figures 1 and 2, transit time to Bogoslof should be an additional 1.9 Myr longer than to Umnak, assuming ${ }^{10} \mathrm{Be}$ travels with the slab to a point beneath the volcano, and that mantle transit time is short relative to the ${ }^{10} \mathrm{Be}$ half-life. That the Bogoslof
${ }^{10} \mathrm{Be} /{ }^{9} \mathrm{Be}$ ratio is similar to the front rather than a factor of two lower (i.e., slightly more than one additional half-life in transit) is striking, and may be explained by a larger sediment contribution to the rear arc, perhaps because sediment melts are focused farther back than the volcanic front and so sediments are more likely to reach their solidus at greater slab depths [Ryan et al., 1995; Plank and Kelley, 2001]. Alternatively, faster transport rates for Be from the slab through the mantle to the surface in the rear arc could explain the high Bogoslof values. The presence of $U$ series disequilibria in the volcanic front lavas and at Bogoslof, however, argues that fluid and magma transport time through the mantle are short relative to the ${ }^{10} \mathrm{Be}$ half-life.

[42] The second striking observation is that ${ }^{10} \mathrm{Be} /{ }^{9} \mathrm{Be}$ is highest where the subducted sediment flux is highest (Figures 2b and 12) [e.g., Plank and Langmuir, 1993, 1998]. However, in the central Aleutians the flux of sediment depends on its thickness on the down-going plate, not on changes in convergence rate (Figure 2). Greater sediment thickness will not increase the ${ }^{10} \mathrm{Be}$ in the sediment column, unless the increased sediment contribution is younger than about $8 \mathrm{Ma}$; Figure $2 \mathrm{~b}$ suggests that variations in sediment thickness are due to the location of transform faults and associated grabens formed early in the history of the incoming plate. The implication is that a larger flux of minor and trace elements are transferred from slab to mantle in this region of thicker sediment pile. This could result from either smaller degree melts of the sediments, with correspondingly higher trace element abundances, or greater volumes of such melts at similar degrees of melting. In this region, the down-going slab is most shallow beneath the volcanic front [England, 2001]; perhaps an unusual P-T path for the slab through this section of the arc could reconcile the observations.

[43] The flux of ${ }^{10} \mathrm{Be}$ in arc magmas may be compared with the amount subducted to the depths of magma generation, assuming steady state conditions. Such calculations have been presented for Japan and central America by Morris et al. [2002]. The flux of ${ }^{10} \mathrm{Be}$ erupted from an arc is controlled by the fraction of the sediment column that subducts to depth and the efficiency with which $\mathrm{Be}$ is extracted from the slab and cycled through the mantle. The flux balance is necessarily dependent on magma production rates, which are typically poorly known. Using a mean ${ }^{10} \mathrm{Be}$ in the lavas from the oceanic segment of the Aleutian arc of $3.0 \times 10^{-6}$ atoms $g^{-1}$, the ${ }^{10}$ Be profile for 


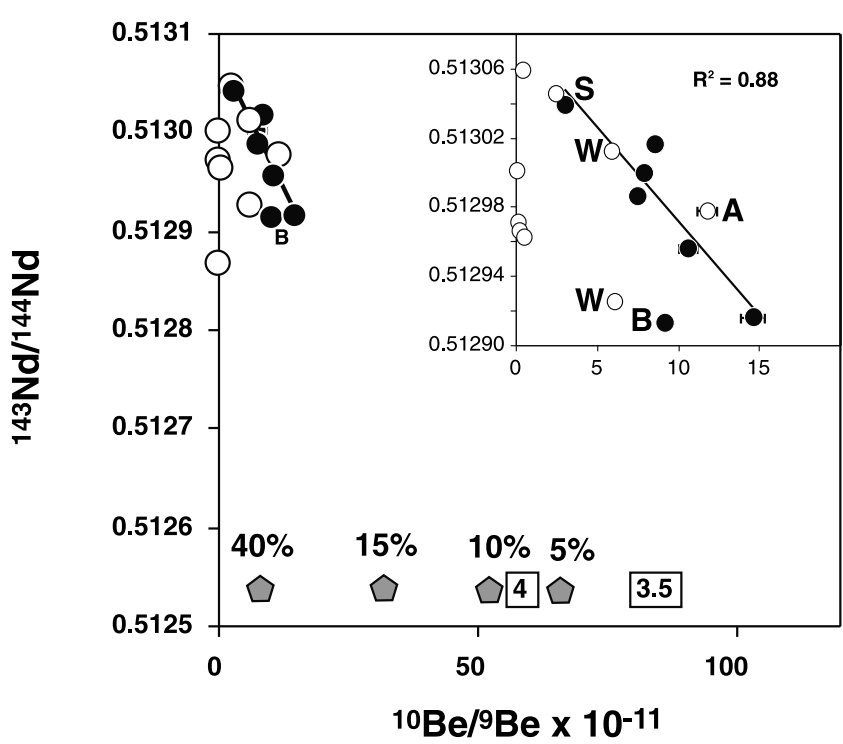

Figure 12. Be-Nd mixing model for Aleutian-Alaskan lavas using sediment ${ }^{10} \mathrm{Be}$ parameters from Tables 2 and 3. End-member $\mathrm{Nd}$ concentration and isotope ratios are given in Figure 9. The inset shows that the lavas fall on or close to a single trend and when restricted to the lavas from the volcanic front through the oceanic section, the correlation coefficient is 0.88 . Lavas from the continental arc that share mixing systematics with the oceanic segment are indicated as S, Shishaldin; W, Westdahl; and A, Aniakchak (one lava only of three measured). The Be-Nd correlation is interpreted as a mixing trend between mantle and a sediment component that is relatively homogeneous with respect to ${ }^{10} \mathrm{Be}$. If the lavas are produced through simple admixing of a sediment melt, the implied ${ }^{10} \mathrm{Be} /{ }^{9} \mathrm{Be}$ ratio of the sedimentary end-member is lower than that predicted for complete sediment subduction with a transit time of $3.5 \mathrm{Myr}$, which is calculated at $83 \times 10^{-11}$. This lower ${ }^{10} \mathrm{Be} /{ }^{9} \mathrm{Be}$ ratio could result from removing the upper $10-15 \%$ of the incoming sediment (accretion of upper 5\% of sediment column gives ${ }^{10} \mathrm{Be}{ }^{/ 9} \mathrm{Be}$ ratio of $71 \times 10^{-11} ; 10 \%=55 ; 15 \%=36$; $40 \%=4$; shaded polygons) or by storing the subducted sediment in the mantle or along the subduction interface for an additional $\sim 0.5-1 \mathrm{Myr}$ (open squares with total transit times in Myr).

DSDP 183 in Figure 7, and a magma production rate of 28 $\mathrm{km}^{3} \mathrm{~km}^{-1} \mathrm{Myr}^{-1}$ [Reymer and Schubert, 1984], the Aleutian arc is erupting $\sim 10 \%$ of the ${ }^{10} \mathrm{Be}$ in the total sediment column, once corrected for decay during subduction. This ${ }^{10} \mathrm{Be}$ recycling efficiency is greater than in Japan and Costa Rica, but lower than in the Marianas or Nicaragua [Zheng et al., 1994; Morris et al., 2002].

[44] The Be-Nd mixing relations in Figure 12 are consistent with addition of a sediment partial melt. With a $2 \%$ melt of the subducting sediment, the range of observed variation can be produced with $<2 \%$ admixture of the sediment component. However, while $\mathrm{Nd}$ and $\mathrm{Be}$ are generally considered more compatible in melt than fluid, it is worth considering whether a fluid component alone could produce the observed variations. Using partitioning information from Johnson and Plank [1999] as a guideline, a fluid that has interacted with the sediment column might be expected to contain 0.25 to $0.5 \mathrm{ppm}{ }^{9} \mathrm{Be}$, while the sediment melt discussed earlier would have $\sim 2-3 \mathrm{ppm}{ }^{9} \mathrm{Be}$. To shift the ${ }^{10} \mathrm{Be} /{ }^{9} \mathrm{Be}$ ratio of the hybridized mantle by the amount required would require $<2 \%$ sediment melt, but $\sim 5-10 \%$ of a fluid component. However, this much fluid would predict $\mathrm{U}$ and $\mathrm{B}$ concentrations and $\mathrm{U} / \mathrm{Th}$ ratios in the lavas much higher than those observed.

\subsection{Fluid Addition and Partial Melting}

[45] The elevated concentrations of fluid mobile elements such as $\mathrm{Cs}$ and the presence of U/Th ratios higher than those in MORB (or the subducted sediments) (Figure 6), are typical of many island arc lavas and provide strong evidence for fluid addition to the source of the Aleutian lavas. However, it is worth noting that the effects of fluid addition are not as easily distinguished from the effects of sediment melts in this arc as they are in many other arcs because of the Ba-, Cs- and U-rich nature of the down-going sediment. ${ }^{238} \mathrm{U}$ excesses peak in the center of the arc (Figure 8a), and, in the simplest model, this reflects the greater convergence (and thus volatile supply) rate in this region.

[46] Previous studies of whole rock U-Th isotope data have used the base of inclined U-Th isotope arrays to provide an estimate of the integrated time elapsed since U addition by fluids [Elliott et al., 1997; Turner et al., 1997]. The Aleutian data are unusual in this regard because the base of the oceanic array is horizontal, projecting back to an initial Th isotope ratio of 1.3, which is also that of the sediment composition (inset to Figure 6). Thus, either the fluid did not contain appreciable Th or, if it did, then it must have had the same $\left({ }^{230} \mathrm{Th} /{ }^{232} \mathrm{Th}\right)$ ratio as the sediment which would imply that the fluid was derived from the sediment [cf. Class et al., 2000]. The flat base to the U-Th array also implies only a short time $(<10 \mathrm{kyr})$ has elapsed since $\mathrm{U}$ addition to the source of these lavas and, if the ${ }^{226} \mathrm{Ra}$ excesses are similarly attributed to fluid addition [Turner et al., 2001b; Sigmarsson et al., 2002], then both the ${ }^{238} \mathrm{U}$ excesses and ${ }^{226} \mathrm{Ra}$ excesses could reflect fluid addition at similar times. This contrasts with the apparent need for more complex, multistage models to explain the isotope disequilibria data in some other arcs (e.g., Tonga-Kermadec [Turner et al., 2000]), although large ${ }^{226} \mathrm{Ra}$ excesses behind the arc front at Bogoslof may still require ${ }^{226} \mathrm{Ra}$ in-growth in the down-going plate. However, while the time information implied by the base of the oceanic U-Th array is relatively straightforward, less clear is the origin of the higher $\left({ }^{230} \mathrm{Th} /{ }^{232} \mathrm{Th}\right)$ ratios observed in some of the oceanic and many of the continental samples. Thorium 230 in-growth during ascent and/or storage of melts is the simplest, but in some ways the least satisfactory, explanation because ${ }^{226} \mathrm{Ra}$ excesses are preserved in these same lavas. Moreover, this cannot be the explanation for the ${ }^{230} \mathrm{Th}$ excesses preserved in several of the lavas.

[47] The ${ }^{230} \mathrm{Th}$ excesses in lavas from divergent and intraplate settings are a hallmark of dynamic, and/or porous flow, decompression melting effects (see Elliott [1997] for a recent review), whereas in island arcs, $\mathrm{U}$ and $\mathrm{Ra}$ excesses are a feature usually attributed to addition of these fluidmobile elements from the altered ocean crust [Gill and Williams, 1990; McDermott and Hawkesworth, 1991; Turner et al., 2001b]. However, it is also possible that arc rocks with $\mathrm{U}$ and $\mathrm{Ra}$ excesses have been displaced to higher 
Th isotope ratios by the effects of dynamic partial melting, in which case the challenge is to resolve isotope disequilibria resulting from fluid addition from that produced during partial melting [cf. Bourdon et al., 1999]. The effects of melting on U-Th isotopes are least ambiguous in rocks that have ${ }^{230} \mathrm{Th}$ excesses, but these are relatively rare in arcs. When ${ }^{230} \mathrm{Th}$ excesses are observed, they reflect a smaller relative contribution from the fluid component, and they tend to occur on continental margins, perhaps suggesting that the length of the melting column or the thermal effect of the overlying lithosphere may also exert an important control on their development. The ${ }^{230} \mathrm{Th}$ enriched Alaskan lavas (Figure 6) therefore provide a rare opportunity to examine the role of melting-induced U-Th fractionation in arc lavas.

[48] Ra-Th isotopes differ from U-Th isotopes in that both partial melting and fluid addition result in the same sense of fractionation and displacement to elevated $\left({ }^{226} \mathrm{Ra} /{ }^{230} \mathrm{Th}\right)$ ratios. Thus, on a plot of $\left({ }^{238} \mathrm{U} /{ }^{230} \mathrm{Th}\right)$ versus $\left({ }^{226} \mathrm{Ra} /{ }^{230} \mathrm{Th}\right),{ }^{226} \mathrm{Ra}$ excesses occur in Aleutian-Alaskan rocks that have both ${ }^{238} \mathrm{U}$ and ${ }^{230} \mathrm{Th}$ excesses (Figure $6 \mathrm{~b}$ ), and those ${ }^{226} \mathrm{Ra}$ excesses are of a similar magnitude to those found at intraplate and extensional settings $[$ Rubin and Macdougall, 1988; Volpe and Goldstein, 1993; Sims et al., 1999; Chabaux and Allègre, 1994; Pietruszka et al., 2001]. $\left.{ }^{226} \mathrm{Ra}{ }^{230} \mathrm{Th}\right)$ activities in other arcs extend to higher values than those observed in MORB and OIB, and correlations with $\mathrm{Ba} / \mathrm{Th}$ suggest that the ${ }^{226} \mathrm{Ra}^{230} \mathrm{Th}$ disequilibria resulted from fluid addition, rather than partial melting [Turner et al., 2001b]. However, the presence of ${ }^{230} \mathrm{Th}$ excesses, and a lack of a good correlation between $\mathrm{Ba} / \mathrm{Th}$ and $\left({ }^{226} \mathrm{Ra} /{ }^{230} \mathrm{Th}\right)$ in the Alaskan-Aleutian rocks (inset to Figure 6b) suggests that this model may be less valid here (although it is also true that $\mathrm{Ba} / \mathrm{Th}$ ratios reflect sediment, as well as fluid, addition in this arc). Thus we shall explore models in which the $\left({ }^{226} \mathrm{Ra} /{ }^{230} \mathrm{Th}\right)$ disequilibria in the rocks with ${ }^{230} \mathrm{Th}$ excesses reflect melt generation processes. In principle, there is no reason to suppose that partial melting did not cause similar fractionations of $\left({ }^{238} \mathrm{U} / 230 \mathrm{Th}\right)$ and $\left({ }^{226} \mathrm{Ra} /{ }^{230} \mathrm{Th}\right)$ in rocks with both ${ }^{238} \mathrm{U}$ and ${ }^{226} \mathrm{Ra}$ excesses.

[49] In recent partial melting models U-Th isotope fractionation is most sensitive to the rate of passage of peridotite matrix through the melting region. Beneath ridges and ocean islands this equates to the upwelling rate which is directly linked to the melting rate, whereas Ra-Th fractionation is largely controlled by the residual porosity [e.g., McKenzie, 1985; Williams and Gill, 1989; Spiegelman and Elliott, 1993]. Beneath arcs the peridotite matrix may move downward through the melt zone in response to induced convection in the mantle wedge but might also move upward due to localized regions of low buoyancy or if the wedge convection flow pattern curves upward beneath the arc front [e.g., Furukawa, 1993a, 1993b].

[50] A reasonable assumption in the ridge and ocean island models is that the source starts in secular equilibrium, but this is not true for arcs where fluid addition could cause disequilibrium prior to melting. U-Th-Ra fractionation under those conditions has been less well investigated. In Figure 13 we use the equations of Williams and Gill [1989] to explore the consequences of partial melting of a source having a ${ }^{238} \mathrm{U}$ excess and compare that to the more familiar model of melting of an equilibrium source. Because the $\left({ }^{226} \mathrm{Ra} /{ }^{230} \mathrm{Th}\right)$ ratios in the Alaska-Aleutian lavas are similar to those observed in intraplate lavas we have modeled the case in which any ${ }^{226} \mathrm{Ra}$ excesses resulting from fluid addition have decayed back to equilibrium by the time of partial melting (i.e., the source is in Ra-Th equilibrium). Clearly, the ${ }^{226} \mathrm{Ra}$ excesses would be larger if this assumption was not made but we use this as an illustrative endmember model (because $D_{R a}$ is very small relative to $D_{T h}$ [Wood et al., 1999], moderate ${ }^{226} \mathrm{Ra}$ excesses are also produced by melting so long as the porosity is similar to or less than $\mathrm{D}_{\mathrm{Th}}$ ).

[51] For a given set of distribution coefficients, the size of the ${ }^{226} \mathrm{Ra}$ excesses are controlled by the residual porosity irrespective of whether the source begins in isotope equilibrium or with ${ }^{238} \mathrm{U}$ excess (Figure 13a). However, the effects of the velocity of the matrix through the melting region on ${ }^{238} \mathrm{U}^{230} \mathrm{Th}$ fractionation are increasingly pronounced as the $\left({ }^{238} \mathrm{U}^{230} \mathrm{Th}\right)$ ratio of the source becomes $>1$ and this results in rotated arrays at a given matrix velocity on the U-Th equiline diagram (Figure 13b). This is because the relative effects of ${ }^{230} \mathrm{Th}$ addition resulting from in-growth in the matrix are more pronounced when the source is U-rich and Th-poor (i.e., sources with ${ }^{238} \mathrm{U}$ excesses). As in the case of melting of an equilibrium source, the effect of dynamic partial melting essentially results in an increase in $\left({ }^{230} \mathrm{Th} /{ }^{232} \mathrm{Th}\right)$ and a vertical shift on a U-Th equiline diagram. For source regions in U excess this shift is toward the equiline (Figure 13b) which leads to a consequent decrease in the amount of disequilibria (i.e., toward lower $\left({ }^{238} \mathrm{U}^{230} \mathrm{Th}\right)$ on Figure 13a). In fact, at very low matrix velocity rates it is possible to cross the equiline to produce magmas with ${ }^{230} \mathrm{Th}$ excess from a source originally in ${ }^{238} \mathrm{U}$ excess (Figure 13). Thus, while this is by no means intended as an exhaustive treatment of the effects of partial melting beneath arcs [see also Bourdon et al., 1999; Thomas et al., 2002], the implications are potentially quite profound. For example, partial melting of U excess sources can produce inclined arrays [Elliott et al., 2001] that have traditionally been interpreted to reflect the time elapsed since $\mathrm{U}$ addition by fluids and independent information may be required to distinguish between these two interpretations [e.g., Pa isotopes, Bourdon et al., 1999]. For the Alaska-Aleutian lavas, the effects of dynamic partial melting could explain both the samples that have $\left({ }^{230} \mathrm{Th} /{ }^{232} \mathrm{Th}\right)$ ratios $>1.3$ and the samples with ${ }^{230} \mathrm{Th}$ excesses; this also raises the possibility that the relatively small ${ }^{226} \mathrm{Ra}$ excesses in this arc are entirely due to partial melting rather than fluid addition [cf. Turner and Hawkesworth, 1997]. If correct, our data imply matrix flow through the melting region on the order of several centimeters per year and residual porosities between 0.02 and $0.002 \%$. It is intriguing that such figures are similar to the upwelling rates and porosities inferred for ridges and ocean islands [e.g., Sims et al., 1999], but decreasing the rate of flow of matrix through the melting region has a similar effect to expanding the length scale of the melting region, or decreasing the accumulated melt fraction at a constant residual porosity.

\subsection{Tectonic Controls on Along-Arc Variation in Magma Composition}

[52] The analyzed lavas reveal that contributions from different source components vary more or less systemati- 

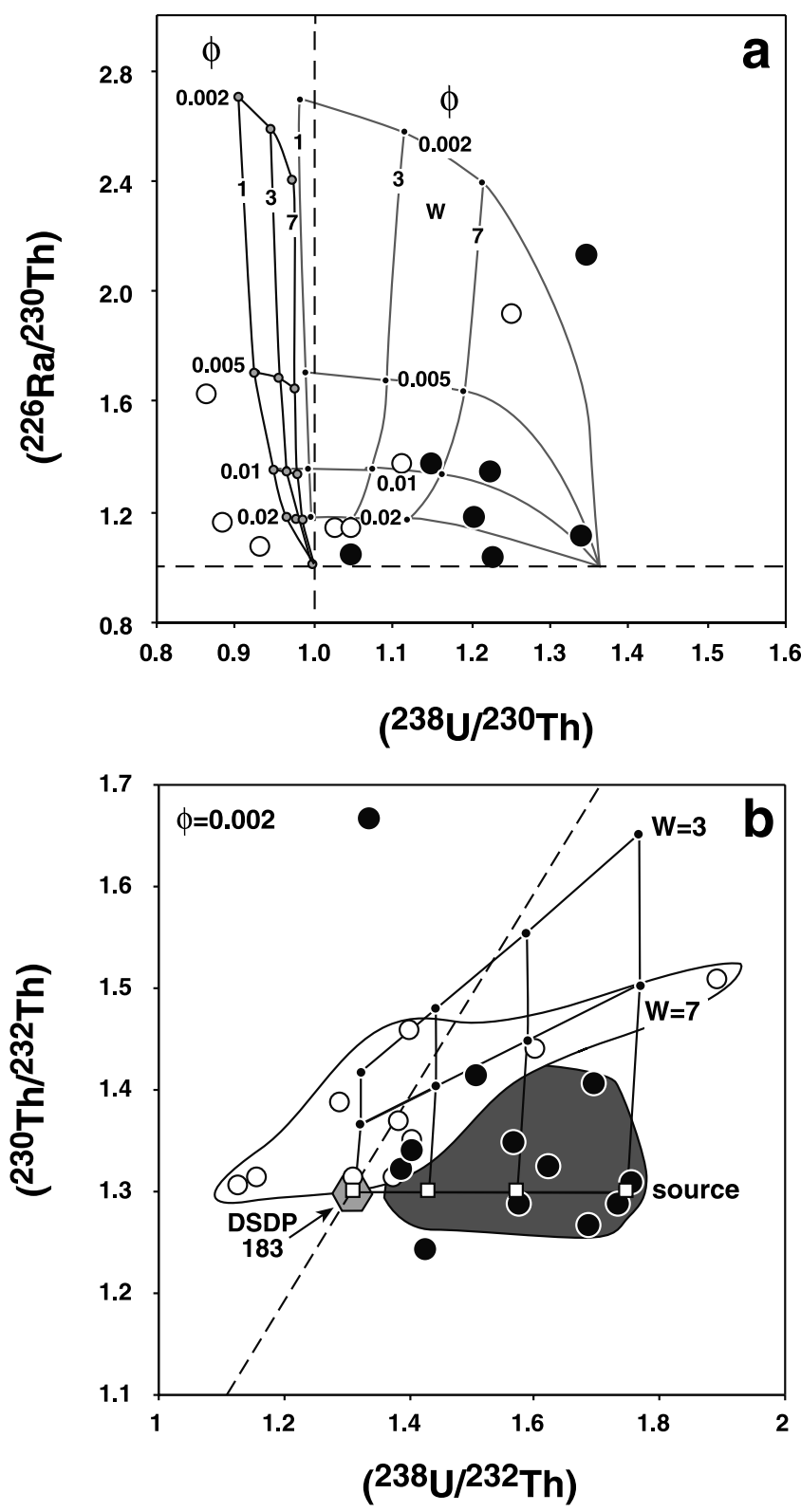

Figure 13. (a) U-Th versus $\mathrm{Ra}-\mathrm{Th}$ disequilibria with grids showing the effects of dynamic partial melting of a source in U-Th equilibrium and one having a U excess. Calculations were made using the equations of Williams and Gill [1989] and are contoured for velocity of the matrix through the melting region (W) and residual porosity $(\phi)$. Starting compositions for the two grids are $0.08 \mathrm{ppm} \mathrm{U}$ and $0.19 \mathrm{ppm}$ Th and $0.06 \mathrm{ppm} U$ and $0.11 \mathrm{ppm}$, respectively Th with $\left({ }^{230} \mathrm{Th} /{ }^{232} \mathrm{Th}\right)=1.3$ and $\left({ }^{226} \mathrm{Ra} /{ }^{230} \mathrm{Th}\right)$ at equilibrium. (b) UTh equiline diagram showing how the effects of dynamic partial melting of sources with $U$ excesses result in inclined arrays. The starting compositions have a Th isotope composition dictated by the sediment (1.3) plus a variable relative fluid addition of $U$ as indicated by the open squares. Bulk partition coefficients used in both Figures $13 \mathrm{a}$ and $13 \mathrm{~b}$ are $\mathrm{D}_{\mathrm{U}}=0.0038 ; \mathrm{D}_{\mathrm{Th}}=0.003 ; \mathrm{D}_{\mathrm{Ra}}=4 \times 10^{-5}$. The dimension of the melting region is $70 \mathrm{~km}$, and the total extent of melting is $12 \%$. cally with changes in plate tectonic configuration along the arc. For example, Th and $\mathrm{Nd}$ isotopes require variable $1-3 \%$ sediment addition to Alaska-Aleutian mantle sources. This depends on the position along the arc, and the supply of slab-derived elements, which is greatest in the center of the arc. $\mathrm{Th} / \mathrm{Nb}$ and $\mathrm{Th} / \mathrm{Nd}$ ratios are also higher in the center of the arc, and since these have been attributed to partial melting of the subducted sediments, it appears that the slab was hot enough for the subducted sediments and possibly basalts (see below) to melt only between $165^{\circ} \mathrm{W}$ and $185^{\circ} \mathrm{W}$. This constrains the thermal structure and suggests that the slab surface temperatures are cooler to the east and near west (excluding the zone of slab tearing in the far west).

[53] Slab surface temperatures depend on convergence rate, plate thermal structure, and mantle viscosity [Davies and Stevenson, 1992; Peacock, 1996], and thermal evolution of the wedge is governed by competition between the cooling effects of the down-going plate and advection of warmer mantle into the wedge [Kincaid and Selwyn Sacks, 1997]. Because the dip of the Pacific slab steepens from east to west along the Alaska-Aleutian arc, the thermal structure of the wedge and slab will also change. Corner flow is inhibited where the plate has the shallowest dip, and higher wedge temperatures occur where the plate dip is steepest, in the center of the arc [Creager and Boyd, 1991]. Because wedge temperatures are highest here, so too will be the slab surface temperatures, assuming the slab and wedge are thermally coupled. In keeping with our observations, this would predict that sediment melts will most likely occur in the center of the Aleutian arc.

[54] As noted by Johnson and Plank [1999], the central arc slab surface temperatures required for sediments to melt at suitable pressures are significantly higher than those predicted by most current geodynamic models [e.g., Davies and Stevenson, 1992; Peacock, 1996]. Our data require a small $(1-3 \%)$ addition of a melt component (either sediment, basalt, or both) from the subducting plate in the central Aleutians. Because the inferred degree of melting of this component is very small, the temperatures are also constrained to be close to the solidus of the relevant material. Thus, if there is a $1 \%$ contribution of melt from the subducted basalt in the central Aleutians (see Figure 11a) this requires slab surface temperatures of the order of $\sim 740^{\circ} \mathrm{C}$, based on the fluid-saturated solidus for basalt inferred at $3 \mathrm{GPa}$ [e.g., Schmidt and Poli, 1998]. However, because the subducted basalt is thermally insulated by the overlying sediment cover, the sediment is likely to melt first and also to a greater extent for a given slab surface temperature. Moreover, the $\mathrm{Be}$ isotope data suggest that it may only be the sediment which melts. Thus, if there is only a narrow P-T space in which the altered oceanic crust dehydrates while the overlying sediments melt, as suggested by Nichols et al. [1996], this would provide a very tight constraint on the thermal structure of the wedge (670$740^{\circ} \mathrm{C}$ at $3 \mathrm{GPa}$ ). Unfortunately, the location of the solidus for subducted sediment is more variable than that of hydrated basalt, due to the larger range in bulk composition and possibly oxygen fugacity. For example, while Nichols et al. [1996] determined the solidus for a red pelagic clay to be $\sim 670^{\circ} \mathrm{C}$ at $3 \mathrm{GPa}$, Johnson and Plank [1999] obtained higher temperatures for a different sediment composition. 


\section{ECV $6-22$ GEORGE ET AL:: VARIATIONS ALONG THE ALASKA-ALEUTIAN ARC}

Therefore the full thermal implications of our data may require refinement by further experimental work. It remains possible that sediment melts are generated at greater depths ( $\sim 200 \mathrm{~km})$, where they would be closer to the sediment solidus and only incorporated where steep subduction geometries allow them to be focused into the arc magma melt zone [Elliott et al., 1997; Plank and Kelley, 2001]. This is supported by the enhanced sediment signal at Bogoslof behind the arc front, but such a model would not seem to predict the observed systematic along-arc variations.

[55] Assuming that the altered oceanic crust has an approximately constant water content, the smooth alongarc variations in orthogonal convergence rate will lead to a greater fluid supply per unit time in areas of fastest subduction. This is consistent with the observation that the relative effects of fluid addition, as measured by the size of ${ }^{238} \mathrm{U}$ excess, mirrors the convergence rates (Figure 8a). It also highlights how in this arc the fluid flux and contributions from melted sediment are both greater in the center of the arc. More strikingly, the volcanic output appears to follow a similar pattern (Figure 2a) and so there is good evidence for a direct link between the rate of fluid supply (based on convergence rate and inferred from the size of ${ }^{238} \mathrm{U}$ excess) and magma output along the AlaskaAleutian arc. This is consistent with fluid-fluxing being the principle control on melt production beneath arcs. It is interesting, therefore, that this same arc also provides some of the clearest evidence for dynamic melting effects in the lavas with ${ }^{230} \mathrm{Th}$ excesses (section 5.4) and, by analogy, for those with $\left({ }^{230} \mathrm{Th} /{ }^{232} \mathrm{Th}\right.$ ) activities greater than 1.3 (see Figure 13).

[56] Figure 13b highlights that the field for the continental volcanic rocks includes samples both in ${ }^{230} \mathrm{Th}$ excess and those displaced to higher $\left({ }^{230} \mathrm{Th} /{ }^{232} \mathrm{Th}\right)$ values than those from the oceanic sector. As discussed above, this requires some sort of dynamic melting process in which melt and matrix flow through the melting region at different velocities; there are two alternative interpretations. In principle, this could be due to downward directed flow of the peridotite matrix through the melt zone and the effects of flux-melting on $U$ series disequilibria under these conditions has recently been modeled by [Thomas et al., 2002]. However, the flux-melting model predicts that the effects of melting will be enhanced in areas of slow convergence rate because those will be areas of lowered fluid flux (i.e., less $U$ addition) and slow matrix flow, which will allow greater time for daughter nuclide in-growth [Thomas et al., 2002]. Yet we do not observe ${ }^{230} \mathrm{Th}$ excesses in our western Aleutian samples, where fluid flux should be restricted and matrix flow slowest (Figure 8a). Moreover, the base of the oceanic lava array is flat which seems to allow little scope for Th isotope shifts due to melting effects in those lavas. Instead, the evidence for melting of the sediments and a melting effect on U-Th disequilibria at different places along the arc, combined with this apparent relationship to the nature of the overlying lithosphere, leads us to infer a link to the local thermal structure and/or length of the melting region. Therefore we end by considering whether a component of matrix upwelling beneath the arc, as suggested by Bourdon et al. [1999] for the Tonga-Kermadec arc, might provide a valid alternative explanation for the ${ }^{230}$ Th excesses in Alaska. This has the added attraction that it would reconcile previous major and trace element evidence for decompression melting beneath arcs [Plank and Langmuir, 1988; Pearce and Parkinson, 1993]. Recent temperature-dependent viscosity models predict that the pattern of mantle convection will have a component of upward flow beneath the arc [e.g., Furukawa, 1993a, 1993b]. One of the attractive aspects of these models is that they predict much higher slab-wedge interface temperatures than many current geodynamic models and so can simultaneously resolve the problem of how to facilitate partial melting of the sediments. The rate of upwelling will also be influenced by local thermal gradients and/or the presence of melt or volatiles [Brémond d'Ars et al., 1995]. In the Alaska-Aleutian arc, the presence of a thicker lithospheric lid and the shallower angle of subduction in Alaska could lead to a cooler wedge, greater mantle viscosity and slower upwelling and melting rates beneath the continent. This model will be tested by a detailed study of ${ }^{231} \mathrm{~Pa}^{235} \mathrm{U}$ disequilibria along the arc.

\section{Concluding Remarks}

[57] The Aleutian-Alaskan lavas capture, in a recent time slice of similarly evolved magmas, the way in which the processes of melt generation vary systematically in response to smooth, arc-wide changes in plate tectonic configuration. It has been argued that the Aleutian arc is an exemplar of melts derived from subducted lithospheric sources, and yet the new analyses on the youngest arc lavas show no positive evidence for basaltic crustal melt involvement. From this we suggest that the conditions responsible for the production of such distinctive melts are probably restricted to the far western portion of the arc [Yogodzinski et al., 2001]. Either way, sediment ( \pm basalt) melting is restricted to the center of the arc encompassed by our study, thereby placing stringent constraints on the thermal structure of the slab. Such conditions require slab surface temperatures in the region of $650-740^{\circ} \mathrm{C}$ which are significantly hotter than those inferred from current thermal models for subduction zones [cf. Johnson and Plank, 1999; Kelemen et al., 2003]. The inferred low ${ }^{10} \mathrm{Be} /{ }^{9} \mathrm{Be}$ ratio in the sediment component could be achieved by accretion of the upper $10-15 \%$ of the incoming sediment, or by storing the subducted sediment in the mantle wedge for $\sim 1.5$ Myr. Correlations between orthogonal convergence rate, subaerial volcano volume [Fournelle et al., 1994], and the magnitude of ${ }^{238} \mathrm{U}$ excesses along the arc suggest that the amount of magma produced depends on the size of the fluid flux supplied to the wedge. Additionally, there is an observable melting effect on U-Th disequilibria which becomes increasingly pronounced from the oceanic to the continental arc regime. The transition from oceanic to continental arc therefore provides a unique window into the interplay between fluid-fluxed and melting driven disequilibria. We suggest that the generation of sediment melts in the center of the arc together with the dominance of a melting effect on U-Th fractionation farther east beneath Alaska are both consequences of the change from fast and steep to shallow and slow plate subduction. Combined with increasing lithospheric lid thickness these tectonic factors together control the slab and wedge temperatures and matrix flow rates through the melting region along the arc. 
[58] Acknowledgments. We are very grateful to Mike Perfit Peter Stelling, Michelle Coombs, Jim Brophy, Bob Kay, Sue Kay, and John Power for generously providing Aleutian samples for this study. John Foden and David Bruce (Adelaide University) kindly allowed us to use their isotope facilities for which we are very grateful. We would also like to thank Pete Evans, Mabs Gilmour, Louise Thomas, Derek Vance, and Peter van Calsteren at the Open University for analytical help. Julian Pearce is thanked for performing the ICP-MS analyses. We are very grateful to Terry Plank for discussions on the origin of Ce anomalies and for donating her unpublished analysis of SAR 7 to complete our database. Discussions with John Eichelberger, Georg Zellmer, and Dave Scholl have helped to shape the thoughts presented here. The idea to explore the effects of dynamic melting of sources having U excesses was suggested by Tim Elliott, to whom we are also grateful for helpful discussions. Bruce Nelson, Connie Class, and Peter Kelemen are thanked for their critical and helpful reviews, and the tranquility of Bhutan aided the revision process. This work was funded by NERC grant GR3/11701, and S.P.T. acknowledges a Royal Society University Research Fellowship.

\section{References}

Arth, J. G., Isotopic composition of the igneous rocks of Alaska, in The Geology of North America, vol. G-1, The Geology of Alaska, edited by G. Plafker and H. C. Berg, pp. 781-796, Geol. Soc. of Am., Boulder, Colo., 1994.

Belshaw, N. S., P. A. Freedman, R. K. O’Nions, M. Frank, and Y. Guo, A new variable dispersion double-focusing plasma mass spectrometer with performance illustrated for $\mathrm{Pb}$ isotopes, Int. J. Mass Spectrom. Ion Processes, 181, 51-58, 1998.

Ben Othman, D., W. M. White, and J. Patchett, The geochemistry of marine sediments, island arc magma genesis, and crust-mantle recycling, Earth Planet. Sci. Lett., 94, 1-21, 1989.

Blundy, J. D., J. A. Robinson, and B. J. Wood, Heavy REE are compatible in clinopyroxene on the spinel lherzolite solidus, Earth Planet. Sci. Lett., 160, 493-504, 1998.

Bourdon, B., S. Turner, and C. Allègre, Melting dynamics beneath the Tonga-Kermadec island arc inferred from ${ }^{231} \mathrm{~Pa}^{235} \mathrm{U}$ systematics, Science, 286, 2491-2493, 1999.

Brémond d'Ars, J., C. Jaupart, and R. S. J. Sparks, Distribution of volcanoes in active margins, J. Geophys. Res., 100, 20,421-20,432, 1995.

Brenan, J. M., H. F. Shaw, F. J. Ryerson, and D. L. Phinney, Mineralaqueous fluid partitioning of trace elements at $900^{\circ} \mathrm{C}$ and $2.0 \mathrm{GPa}$ : Constraints on the trace element geochemistry of mantle and deep crustal fluids, Geochim. Cosmochim. Acta, 59, 3331-3350, 1995.

Brophy, J. G., Andesites from northeastern Kanaga island, Aleutians; Implications for calc-alkaline fractionation mechanisms and magma chamber development, Contrib. Mineral. Petrol., 104, 568-581, 1990.

Chabaux, F., and C. J. Allègre, ${ }^{238} \mathrm{U}_{-}{ }^{230} \mathrm{Th}-{ }^{226} \mathrm{Ra}$ disequilibria in volcanics: A new insight into melting conditions, Earth Planet. Sci. Lett., 126, 61 74, 1994.

Class, C., D. M. Miller, S. L. Goldstein, and C. H. Langmuir, Distinguishing melt and fluid subduction components in Umnak volcanics, Aleutian arc, Geochem. Geophys. Geosyst., 1, Paper number 1999GC000010, 2000.

Cohen, A. S., and R. K. O’Nions, Melting rates beneath Hawaii: Evidence from uranium series isotopes in recent lavas, Earth Planet. Sci. Lett., 120, $169-175,1993$.

Condomines, M., and O. Sigmarsson, Why are so many arc magmas close to ${ }^{238} \mathrm{U}-{ }^{230} \mathrm{Th}$ radioactive equilibrium?, Geochim. Cosmochim. Acta, 57, 4491-4497, 1993.

Coombs, M. L., J. C. Eichelberger, and M. Rutherford, Magma storage and mixing conditions for the 1953-1974 eruptions of southwest Trident volcano, Katmai National Park, Alaska, Contrib. Mineral. Petrol., 140, 99-118, 2001.

Creager, K. C., and T. M. Boyd, The geometry of Aleutian subduction: Three-dimensional kinematic flow model, J. Geophys. Res., 96, 2293 2307, 1991.

Creager, J. S., et al., Initial Reports of the Deep Sea Drilling Project, vol. 19, U.S. Govt. Print. Off., Washington, D. C., 1973.

Davies, J. H., and D. J. Stevenson, Physical model of source region of subduction zone volcanics, J. Geophys. Res., 97, 2037-2070, 1992.

Defant, M. J., and M. S. Drummond, Derivation of some modern arc magmas by melting of young subducted lithosphere, Nature, 347, $662-665,1990$

Defant, M. J., and P. Kepezhinskas, Evidence suggests slab melting in arc lavas, Eos Trans. $A G U, 82,65-69,2001$.

DeMets, C., R. G. Gordon, D. F. Argus, and S. Stein, Effect of recent revisions to the geomagnetic reversal time scale on estimates of current plate motions, Geophys. Res. Lett., 21, 2191-2194, 1994.

Ellam, R. M., and C. J. Hawkesworth, Is average continental crust generated at subduction zones?, Geology, 16, 314-317, 1988.
Elliott, T., Fractionation of $\mathrm{U}$ and $\mathrm{Th}$ during mantle melting: A reprise, Chem. Geol., 139, 165-183, 1997.

Elliott, T., T. Plank, A. Zindler, W. White, and B. Bourdon, Element transport from slab to volcanic front at the Mariana arc, J. Geophys. Res., 102, $14,991-15,019,1997$

Elliott, T., A. Heumann, and G. Koetsier, U-series constraints on melting beneath the Marianas, paper presented at Meeting on Intra-oceanic Subduction Systems: Tectonic and Magmatic Processes, Geol. Soc., London, 2001.

England, P. C., Why are arc volcanoes where they are?, Eos Trans. $A G U$, 82(47), 11, Fall Meet. Suppl. Abstract T22D-11, 2001.

Evans, B. W., Phase relations of epidote blueschists, Lithos, 25, 3-23, 1990.

Falloon, T. J., D. H. Green, C. J. Hatton, and K. L. Harris, Anhydrous partial melting of a fertile and depleted peridotite from 2 to $30 \mathrm{~kb}$ and application to basalt petrogenesis, J. Petrol., 29, 1257-1282, 1988.

Fliedner, M. M., and S. L. Klemperer, Crustal structure transition from oceanic arc to continental arc, eastern Aleutian Islands and Alaska Peninsula, Earth Planet. Sci. Lett., 179, 567-579, 2000.

Fournelle, J. H., B. D. Marsh, and J. D. Myers, Age, character and significance of Aleutian arc volcanism, in The Geology of North America, vol. G-1, The Geology of Alaska, edited by G. Plafker and H. C. Berg, pp. 723-758, Geol. Soc. of Am., Boulder, Colo., 1994.

Furukawa, Y., Depth of the decoupling interface and thermal structure under arcs, J. Geophys. Res., 98, 20,005-20,013, 1993a.

Furukawa, Y., Magmatic processes under arcs and the formation of the volcanic front, J. Geophys. Res., 98, 8309-8319, 1993b.

Geist, E. L., J. R. Childs, and D. W. Scholl, The origin of summit basins of the Aleutian Ridge: Implications for block rotation of an arc massif, Tectonics, 7, 327-341, 1988.

Gill, J. B., Orogenic Andesites and Plate Tectonics, 390 pp., SpringerVerlag, New York, 1981.

Gill, J. B., and R. W. Williams, Th isotope and U-series studies of subductionrelated volcanic rocks, Geochim. Cosmochim. Acta, 54, 1427-1442, 1990.

Halliday, A. N., D.-C. Lee, S. Tommasini, G. R. Davies, C. R. Paslick, J. G. Fitton, and D. E. James, Incompatible trace elements in OIB and MORB and source enrichment in the sub-oceanic mantle, Earth Planet. Sci. Lett., 133, 379-395, 1995.

Hawkesworth, C. J., S. P. Turner, F. McDermott, D. W. Peate, and P. van Calsteren, U-Th isotopes in arc magmas: Implications for element transfer from the subducted crust, Science, 276, 551-555, 1997.

Hildreth, W., The compositionally zoned eruption of 1912 in the Valley of Ten Thousand Smokes, Katmai National Partk, Alaska, J. Volcanol. Geotherm. Res., 18, 1-56, 1983.

Hoogewerff, J. A., M. J. van Bergen, P. Z. Vroon, J. Hertogen, R. Wordel, A. Sneyers, A. Nasution, J. C. Varekamp, H. L. E. Moens, and D. Mouchel, U-series, $\mathrm{Sr}-\mathrm{Nd}-\mathrm{Pb}$ isotope and trace-element systematics across an active island arc-continent collision zone: Implications for element transfer at the slab-wedge interface, Geochim. Cosmochim. Acta, 61, 1057$1072,1997$.

Johnson, K. E., R. S. Harmon, J. M. Richardson, S. Moorbath, and D. F. Strong, Isotope and trace element geochemistry of Augustine volcano, Alaska: Implications for magmatic evolution, J. Petrol., 37, 95-115, 1996.

Johnson, M. C., and T. Plank, Dehydration and melting experiments constrain the fate of subducted sediments, Geochem. Geophys. Geosyst, 1, Paper number 1999GC000014, 1999.

Kay, R. W., Aleutian magnesian andesites: Melts from subducted Pacific Ocean crust, J. Volcanol. Geotherm. Res., 4, 117-132, 1978.

Kay, R. W., Volcanic arc magmas: Implications of a melting-mixing model for element recycling in the crust-upper mantle system, J. Geol., 88, 497-522, 1980

Kay, S. M., and R. W. Kay, Creation and destruction of lower continental crust, Geol. Rundsch., 80, 259-278, 1991.

Kay, S. M., and R. W. Kay, Aleutian magmas in space and time, in The Geology of North America, vol. G-1, The Geology of Alaska, edited by G. Plafker and H. C. Berg, pp. 687-722, Geol. Soc. of Am., Boulder, Colo., 1994.

Kelemen, P. B., Genesis of high Mg\# andesites and the continental crust, Contrib. Mineral. Petrol., 120, 1-19, 1995.

Kelemen, P. B., S. R. Hart, and S. Bernstein, Silica enrichment in the continental upper mantle lithosphere via melt/rock reaction, Earth Planet. Sci. Lett., 164, 387-406, 1998.

Kelemen, P. B., G. M. Yogodzinski, and D. W. Scholl, Along-strike variation in lavas of the Aleutian island arc: Implications for the genesis of high Mg\# andesite and the continental crust, in Geophys. Monogr. Ser., edited by J. Eiler, AGU, Washington, D. C., in press, 2003.

Kienle, J., and J. E. Swanson, Volcanism in the eastern Aleutian arc; Late Quaternary and Holocene centers, tectonic setting and petrology, J. Volcanol. Geotherm. Res., 17, 393-432, 1983. 
Kienle, J., P. R. Kyle, S. Self, R. J. Motyka, and V. Lorenz, Ukinrek Maars, Alaska, 1. April 1977 eruption sequence, petrology and tectonic setting, J. Volcanol. Geotherm. Res., 7, 11-37, 1979.

Kincaid, C., and I. Selwyn Sacks, Thermal and dynamical evolution of the upper mantle in subduction zones, J. Geophys. Res., 102, 12,29512,315, 1997.

Koizumi, I., The late Cenozoic diatoms of Sites 183-193, Leg 19 Deep Sea Drilling Project, Initial Rep. Deep Sea Drill. Proj., 19, 805-856, 1973.

Langmuir, C. H., E. M. Klein, and T. Plank, Petrological systematics of mid-ocean ridge basalts: Constraints on melt generation beneath ocean ridges, in Mantle Flow and Melt Generation at Mid-Ocean Ridges, Geophys. Monogr. Ser, vol. 71, edited by J. P. Morgan, D. K. Blackman and J. M. Sinton, pp. 183-280, AGU, Washington, D. C., 1992.

LeMaitre, R. W., et al., A Classification of Igneous Rocks and Glossary of Terms, Blackwell, Malden, Mass., 1989.

Lundstrom, C. C., J. Gill, Q. Williams, and M. R. Perfit, Mantle melting and basalt extraction by equilibrium porous flow, Science, 270, 19581961, 1995.

Marsh, B. D., The Aleutians, in Andesites, edited by R. S. Thorpe, pp. 99115, John Wiley, New York, 1982.

McCulloch, M. T., and M. R. Perfit, ${ }^{143} \mathrm{Nd} /{ }^{144} \mathrm{Nd},{ }^{87} \mathrm{Sr} /{ }^{86} \mathrm{Sr}$ and trace element constraints on the petrogenesis of Aleutian island arc magmas, Earth Planet. Sci. Lett., 56, 167-179, 1981.

McDermott, F., and C. Hawkesworth, Th, Pb and Sr isotope variations in young island arc volcanics and oceanic sediments, Earth Planet. Sci. Lett., 104, 1-15, 1991.

McKenzie, D., ${ }^{230}$ Th $-{ }^{238} \mathrm{U}$ disequilibrium and the melting process beneath ridge axes, Earth Planet. Sci. Lett., 72, 149-157, 1985.

McKenzie, D., and M. J. Bickle, The volume and composition of melt generated by extension of the lithosphere, J. Petrol., 29, 625-679, 1988.

Miller, D. M., S. L. Goldstein, and C. H. Langmuir, $\mathrm{Ce} / \mathrm{Pb}$ and $\mathrm{Pb}$ isotope ratios in arc magmas and the enrichment of $\mathrm{Pb}$ in the continents, Nature, $368,514-520,1994$.

Morris, J. D., and S. R. Hart, Isotopic and incompatible element constraints on the genesis of island arc volcanics from Cold Bay and Amak Islands, Aleutians and implications for mantle structure, Geochim. Cosmochim. Acta, 47, 2015-2030, 1983.

Morris, J. D., and F. Tera, Beryllium isotope systematics of volcanic cross arc chains, J. Conf. Abstr., 5(2), 720, 2000.

Morris, J. D., W. P. Leeman, and F. Tera, The subducted component in island arc lavas: Constraints from Be isotopes and B-Be systematics, Nature, 344, 31-36, 1990.

Morris, J., R. Valentine, and T. Harrison, ${ }^{10}$ Be imaging of sediment accretion and subduction along the northeast Japan and Costa Rica convergence margins, Geology, 30, 59-62, 2002.

Newman, S., J. D. Macdougall, and R. C. Finkel, ${ }^{230} \mathrm{Th}^{-238} \mathrm{U}$ disequilibrium in island arc lavas: Evidence from the Aleutians and the Marianas, Nature, 308, 268-270, 1984.

Newman, S., J. D. Macdougall, and R. C. Finkel, Petrogenesis and ${ }^{230} \mathrm{Th}-{ }^{238} \mathrm{U}$ disequilibrium at Mt. Shasta, California and in the Cascades, Contrib. Mineral. Petrol., 93, 195-206, 1986.

Nichols, G. T., P. J. Wyllie, and C. R. Stern, Experimental melting of pelagic sediment, constraints relevant to subduction, in Subduction Top to Bottom, Geophys. Monogr. Ser, vol. 96, edited by G. E. Bebout et al., pp. 293-298, AGU, Washington, D. C., 1996.

Nye, C. J., and M. R. Reid, Geochemistry of primary and least fractionated lavas from Okmok volcano, central Aleutians: Implications for arc magma genesis, J. Geophys. Res., 91, 10,271-10,287, 1986.

Nye, C. J., and D. L. Turner, Petrology, geochemistry and age of the Spurr volcanic complex, eastern Aleutian arc, Bull. Volcanol., 52, 205-226, 1990.

Nye, C. J., S. E. Swanson, V. F. Avery, and T. P. Miller, Geochemistry of the 1989-1990 eruption of Redoubt volcano: part I. Whole-rock major and trace element chemistry, J. Volcanol. Geotherm. Res., 62, 429-452, 1994.

Nye, C. J., et al., Volcanoes of Alaska, Inf. Circ. 38, Alaska Div. of Geol. and Geophys. Surv., Fairbanks, 1998.

Peacock, S. M., Thermal and petrologic structure of subduction zones, in Subduction Top to Bottom, Geophys. Monogr. Ser., vol. 96, edited by G. E. Bebout et al., pp. 119-133, AGU, Washington, D. C., 1996.

Peacock, S. M., T. Rushmer, and A. B. Thompson, Partial melting of subducting oceanic crust, Earth Planet. Sci. Lett., 121, 227-244, 1994.

Pearce, J. A., and I. J. Parkinson, Trace element models for mantle melting: Application to volcanic arc petrogenesis, in Magmatic Processes and Plate Tectonics, edited by H. M. Prichard et al., Geol. Soc. Spec. Publ., 76, 373-403, 1993.

Peucker-Ehrenbrink, B., A. W. Hofmann, and S. R. Hart, Hydrothermal lead transfer from the mantle to continental crust: The role of metalliferous sediments, Earth Planet. Sci. Lett., 125, 129-142, 1994.

Pickett, D. A., and M. T. Murrell, Observations of ${ }^{231} \mathrm{~Pa} /{ }^{235} \mathrm{U}$ disequilibrium in volcanic rocks, Earth Planet. Sci. Lett., 148, 259-271, 1997.
Pietruszka, A. J., K. H. Rubin, and M. O. Garcia, ${ }^{226} \mathrm{Ra}-{ }^{230} \mathrm{Th}^{238} \mathrm{U}$ disequilibria of historical Kilauea lavas $(1790-1982)$ and the dynamics of mantle melting within the Hawaiian plume, Earth Planet. Sci. Lett., 186, $15-31,2001$.

Plank, T., and K. Kelley, Contrasting sediment input and output at the Izu and Mariana subduction factories, Eos Trans. $A G U, 82(47)$, Fall Meet. Suppl., Abstract T22D-10, 2001.

Plank, T., and C. H. Langmuir, An evaluation of the global variations in the major element chemistry of arc basalts, Earth Planet. Sci. Lett., 90, 349$370,1988$.

Plank, T., and C. H. Langmuir, Tracing trace elements from sediment input to volcanic output at subduction zones, Nature, 362, 739-743, 1993.

Plank, T., and C. H. Langmuir, The chemical composition of subducting sediment and its consequences for the crust and mantle, Chem. Geol., 145, 325-394, 1998.

Potts, P. J., P. C. Webb, and J. S. Watson, Energy-dispersive X-ray fluorescence analysis of silicate rocks for major and trace elements, $X$-Ray Spectrom., 13, 2-15, 1984.

Reagan, M. K., J. D. Morris, E. A. Herrstrom, and M. T. Murrell, Uranium series and beryllium isotope evidence for an extended history of subduction modification of the mantle below Nicaragua, Geochim. Cosmochim. Acta, 58, 4199-4212, 1994.

Reymer, A., and G. Schubert, Phanerozoic addition rates of the continental crust and crustal growth, Tectonics, 3, 63-67, 1984.

Rogers, N. W., and T. N. Setterfield, Potassium and incompatible-element enrichment in shoshonitic lavas from the Tavua volcano, Fiji, Chem. Geol., 118, 43-62, 1994.

Romick, J. D., M. R. Perfit, S. E. Swanson, and R. D. Shuster, Magmatism in the eastern Aleutian arc; Temporal characteristics of igneous activity on Akutan island, Contrib. Mineral. Petrol., 104, 700-721, 1990.

Rubin, K. H., and J. D. Macdougall, ${ }^{226} \mathrm{Ra}$ excesses in mid-ocean ridge basalts and mantle melting, Nature, 355, 158-161, 1988.

Rudnick, R. L., and D. M. Fountain, Nature and composition of the continental crust: A lower crustal perspective, Rev. Geophys., 33, 267-309, 1995.

Ryan J. G., Trace-element systematics of beryllium in terrestrial materials, in Beryllium: Mineralogy, Petrology, and Geochemistry, Rev. Mineral. Geochem., vol. 50, edited by E. S. Grew, pp. 121-146, Mineral. Soc. of Am., Washington, D. C., 2002.

Ryan, J. G., and C. H. Langmuir, Beryllium systematics in young volcanic rocks: Implications for ${ }^{10} \mathrm{Be}$, Geochim. Cosmochim. Acta, 51, $1727-$ 1741, 1987.

Ryan, J. G., and C. H. Langmuir, The systematics of lithium abundances in young volcanic rocks, Geochim. Cosmochim. Acta, 52, 237-244, 1988.

Ryan, J. G., and C. H. Langmuir, The systematics of boron in abundances in volcanic rocks, Geochim. Cosmochim. Acta, 57, 1489-1498, 1993.

Ryan, J. G., J. Morris, F. Tera, W. P. Leeman, and A. Tsvetkov, Cross-arc geochemical variations in the Kurile Arc as a function of slab depth, Science, 270, 625-627, 1995.

Schmidt, M. W., and S. Poli, Experimentally based water budgets for dehydrating slabs and conseuqences for arc magma generation, Earth Planet. Sci. Lett., 163, 361-379, 1998.

Sigmarsson, O., H. Martin, and J. Knowles, Melting of a subducting oceanic crust from U-Th disequilibria in the austral Andean lavas, Nature, 394, 566-569, 1998.

Sigmarsson, O., J. Chmeleff, J. Morris, and L. Lopez-Escobar, Rapid magma transfer from slab derived ${ }^{226} \mathrm{Ra}^{230} \mathrm{Th}$ disequilibria in lavas from southern Chile, Earth Planet. Sci. Lett., 96, 189-196, 2002.

Sims, K. W. W., D. J. DePaolo, M. T. Murrell, W. S. Baldridge, S. Goldstein, D. Clague, and M. Jull, Porosity of the melting zone and variations in the solid mantle upwelling rate beneath Hawaii: Inferences from ${ }^{238} \mathrm{U}-{ }^{230} \mathrm{Th}-{ }^{226} \mathrm{Ra}$ and ${ }^{235} \mathrm{U}-{ }^{231} \mathrm{~Pa}$ disequilibria, Geochim. Cosmochim. Acta, 63, 4119-4138, 1999.

Singer, B. S., J. D. Myers, and C. D. Frost, Mid-Pleistocene lavas from the Seguam Island volcanic center, central Aleutian arc: Closed-system fractional crystallization of a basalt to rhyodacite eruptive suite, Contrib. Mineral. Petrol., 110, 87-112, 1992.

Singer, B. S., W. P. Leeman, M. F. Thirlwall, and N. W. Rogers, Does fracture zone subduction increase sediment flux and mantle melting at subduction zones? Trace element evidence from Aleutian arc basalt, in Subduction Top to Bottom, Geophys. Monogr. Ser., vol. 96, edited by G. E. Bebout et al., pp. 285-291, AGU, Washington, D. C., 1996.

Spiegelman, M., and T. Elliott, Consequences of melt transport for uranium series disequilibrium in young lavas, Earth Planet. Sci. Lett., 118, 1-20, 1993.

Stolper, E., and S. Newman, The role of water in the petrogenesis of Mariana trough magmas, Earth Planet. Sci. Lett., 121, 293-326, 1994. Sun, S.-S., Lead isotopic study of young volcanic rocks from mid-ocean ridges, ocean islands and island arcs, Philos. Trans. R. Soc. London, Ser. $A, 297,409-445,1980$. 
Sun, S. S., and W. F. McDonough, Chemical and isotopic systematics of oceanic basalts: Implications for mantle composition and processes, in Magmatism in Ocean Basins, edited by A. D. Saunders and M. J. Norry, Geol. Soc. Spec. Publ., 42, 313-345, 1989.

Taylor, S. R., and S. M. McLennan, The Continental Crust: Its Composition and Evolution, Blackwell, Malden, Mass., 1985

Tera, F., L. Brown, J. Morris, I. S. Sacks, J. Klein, and R. Middleton, Sediment incorporation in island arc magmas: Inferences from Be-10, Geochim. Cosmochim. Acta, 50, 535-550, 1986.

Thomas, R. B. M. M. Hirschmann, H. Cheng, M. K. Reagan, and L. R. Edwards, $\left({ }^{231} \mathrm{~Pa} /{ }^{235} \mathrm{U}\right)-\left({ }^{230} \mathrm{Th} /{ }^{238} \mathrm{U}\right)$ of young mafic volcanics from $\mathrm{Ni}$ caragua and Costa Rica and the influence of flux melting on U-series systematics of arc lavas, Geochim. Cosmochim. Acta, 66, 4287-4309, 2002.

Todt, W., R. A. Cliff, A. Hanser, and A. W. Hofmann, Evaluation of a ${ }^{202} \mathrm{~Pb}-{ }^{205} \mathrm{~Pb}$ double spike for high precision lead isotope analysis, in Earth Processes: Reading the Isotopic Code, Geophys. Monogr. Ser, vol. 95, edited by A. Basu and S. R. Hart, pp. 429-437, AGU, Washington, D. C., 1996.

Toyoda, K., Y. Nakamura, and A. Masuda, Rare earth elements of Pacific pelagic sediments, Geochim. Cosmochim. Acta, 54, 1093-1103, 1990.

Turner, S., and C. Hawkesworth, The nature of the sub-continental mantle: Constraints from the major-element composition of continental flood basalts, Chem. Geol., 120, 295-314, 1995 .

Turner, S., and C. Hawkesworth, Constraints on flux rates and mantle dynamics beneath island arcs from Tonga-Kermadec, Nature, 389, 568-573, 1997.

Turner, S., C. Hawkesworth, P. van Calsteren, E. Heath, R. Macdonald, and S. Black, U-series isotopes and destructive plate margin magma genesis in the Lesser Antilles, Earth Planet. Sci. Lett., 142, 191-207, 1996.

Turner, S., C. Hawkesworth, N. Rogers, J. Bartlett, T. Worthington, J. Hergt, J. Pearce, and I. Smith, ${ }^{238} \mathrm{U}_{-}{ }^{230} \mathrm{Th}$ disequilibria, magma petrogenesis and flux rates beneath the depleted Tonga-Kermadec arc, Geochim. Cosmochim Acta, 61, 4855-4884, 1997.

Turner, S., F. McDermott, C. Hawkesworth, and P. Kepezhinskas, A Useries study of lavas from Kamchatka and the Aleutians: Constraints on source composition and melting processes, Contrib. Mineral. Petrol., 133, 217-234, 1998.

Turner, S., B. Bourdon, C. Hawkesworth, and P. Evans, ${ }^{226} \mathrm{Ra}^{230}{ }^{23}$ evidence for multiple dehydration events, rapid melt ascent and the time scales of differentiation beneath the Tonga-Kermadec island arc, Earth Planet. Sci. Lett., 179, 581-593, 2000.

Turner, S., P. van Calsteren, N. Vigier, and L. Thomas, Determination of thorium and uranium isotope ratios in low-concentration geological materials using a fixed multicollector ICP-MS, J. Anal. Atom. Spectrosc., 16, 612-615, 2001a.

Turner, S., P. Evans, and C. Hawkesworth, Ultra-fast source-to-surface movement of melt at island arcs from ${ }^{226} \mathrm{Ra}^{230} \mathrm{Th}$ systematics, Science, 292, 1363-1366, 2001b

van Calsteren, P., and J. B. Schwieters, Performance indications for TIMS with a deceleration lens system and post-deceleration detector selection, Int. J. Mass. Spectrom. Ion. Processes, 146/147, 119-129, 1995.

Volpe, A. M., and S. J. Goldstein, ${ }^{226} \mathrm{Ra}^{230} \mathrm{Th}$ disequilibrium in axial and off-axis mid-ocean ridge basalts, Geochim. Cosmochim. Acta, 57, 12331241, 1993.

Von Drach, V., B. D. Marsh, and G. J. Wasserburg, Nd and Sr isotopes in the Aleutians: Multicomponent parenthood of island arc magmas, Contrib. Mineral. Petrol., 92, 13-34, 1986.

Weber, J. M., Constraints from Uranium series disequilibrium on the ages of magmas erupted in 1912 from Novarupta, Katmai National Park, Alaska, M.Sci. thesis, Univ. of Iowa, Iowa City, 1998.

Williams, R. W., and J. B. Gill, Effects of partial melting on the uranium decay series, Geochim. Cosmochim. Acta, 53, 1607-1619, 1989.

Wood, B. J., J. D. Blundy, and J. A. C. Robinson, The role of clinopyroxene in generating U-series disequilibria during mantle melting, Geochim. Cosmochim. Acta, 63, 1613-1620, 1999.

Wood, C., and J. Kienle, Volcanoes of North America, pp. 354, Cambridge Univ. Press, New York, 1990.

Yogodzinski, G. M., and P. B. Kelemen, Slab melting in the Aleutians: Implications of an ion probe study of clinopyroxene in primitive adakite and basalt, Earth Planet. Sci. Lett., 158, 53-65, 1998.

Yogodzinski, G. M., O. N. Volynets, A. V. Koloskov, N. I. Seliverstov, and V. V. Matvenkov, Magnesian andesites and the subduction component in a strongly calc-alkaline series at Piip volcano in the far western Aleutian arc, J. Petrol., 35, 163-204, 1994.

Yogodzinski, G. M., R. W. Kay, O. N. Volynets, A. V. Koloskov, and S. M. Kay, Magnesian andesite in the western Aleutian Komandorsky region: Implications for slab melting and processes in the mantle wedge, Geol. Soc. Am. Bull., 107, 505-519, 1995.

Yogodzinski, G. M., J. M. Lees, T. G. Churikova, F. Dorendorf, G. Woerner, and O. N. Volynets, Geochemical evidence for the melting of subducting oceanic lithosphere at plate edges, Nature, 409, 500-504, 2001. Zheng, S.-H., J. Morris, F. Tera, J. Klein, and R. Middleton, Beryllium isotopic investigation of sedimentary columns outboard of subduction zones, ICOG Abstr. 8, abstract 366, Int. Conf. of Geochronol., Cosmochronol. and Isotope Geochem, Berkeley, Calif., 1994.

R. George, C. Hawkesworth, and S. Turner, Department of Earth Sciences, University of Bristol, Wills Memorial Building, Queens Road, Bristol, BS8 1RJ, UK. (r.m.george@bristol.ac.uk)

J. Morris, Department of Earth and Planetary Sciences, Washington University, Campus Box 1169, One Brookings Drive, Saint Louis, MO 63130-4899, USA.

C. Nye, Alaska Volcano Observatory, Alaska Division of Geological and Geophysical Surveys, 903 Koyukuk Drive, Fairbanks, AK 99775-7320, USA.

J. Ryan, Department of Geology, University of South Florida-Tampa, 4202 E. Fowler Ave., SCA 528, Tampa, FL 33620-5201, USA.

S.-H. Zheng, Department of Earth System Science, University of California, Irvine, 220 Rowland Hall, Irvine, CA 92697, USA. 